\title{
Cultural Resources Survey of the City of Hutto Transmission and Distribution Pumping Stations Phase I Project, City of Hutto, Williamson County, Texas
}

Anne Gibson

Joshua McCormick

Jamie Vandagriff

Kevin Stone

Follow this and additional works at: https://scholarworks.sfasu.edu/ita

Part of the American Material Culture Commons, Archaeological Anthropology Commons, Environmental Studies Commons, Other American Studies Commons, Other Arts and Humanities Commons, Other History of Art, Architecture, and Archaeology Commons, and the United States History Commons

Tell us how this article helped you.

This Article is brought to you for free and open access by the Center for Regional Heritage Research at SFA ScholarWorks. It has been accepted for inclusion in Index of Texas Archaeology: Open Access Gray Literature from the Lone Star State by an authorized editor of SFA ScholarWorks. For more information, please contact cdsscholarworks@sfasu.edu. 


\section{Cultural Resources Survey of the City of Hutto Transmission and Distribution Pumping Stations Phase I Project, City of Hutto, Williamson County, Texas}

\section{Creative Commons License}

\section{(c) (1) \&}

This work is licensed under a Creative Commons Attribution-NonCommercial 4.0 International License 


\section{CULTURAL RESOURCES REPORT}

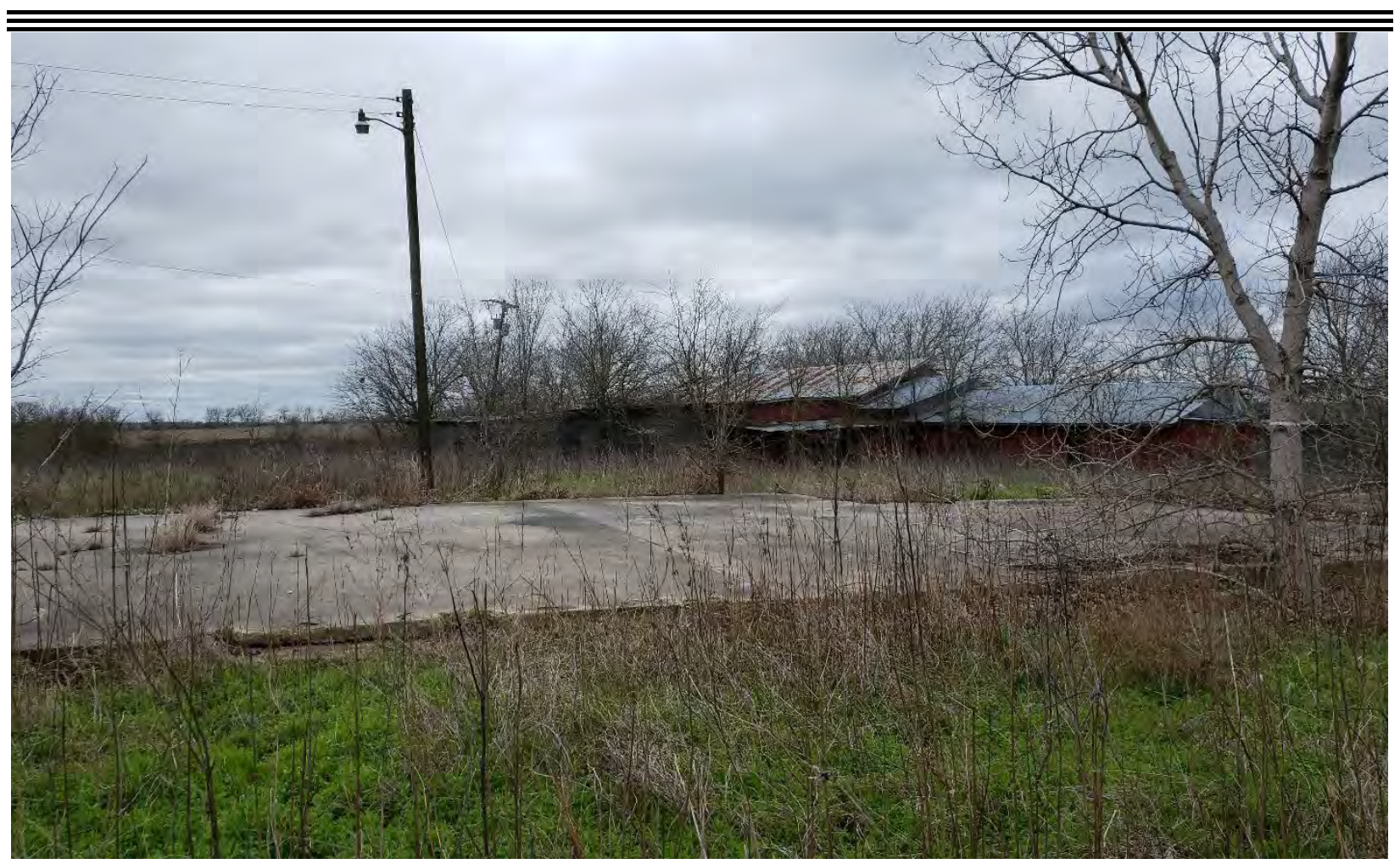

Cultural Resources Survey of the

City of Hutto Transmission and Distribution Pumping Stations Phase I Project, City of Hutto, Williamson County, Texas

Prepared for:

Texas Historical Commission

Texas Antiquities Permit \#9196

On Behalf of:

The City of Hutto

$\&$

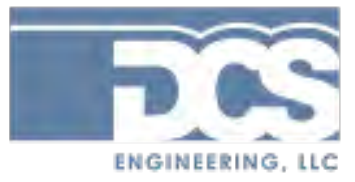

DCS Engineering, LLC

J une 2020

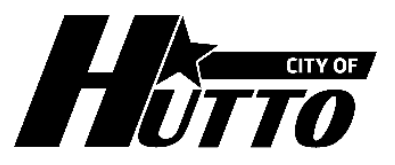


This page intentionally left blank 


\title{
Cultural Resources Survey of the City of Hutto Transmission and Distribution Pumping Stations Phase I Project, City of Hutto, Williamson County, Texas
}

\author{
by \\ Anne Gibson, MA, RPA \\ Project Archeologist, \\ Joshua McCormick, BA \\ Staff Archeologist, \\ Jamie Vandagriff, MA \\ Principal Investigator,
}

$\&$

Kevin Stone, MA, RPA

Vice President - Cultural Resources Director

Submitted to:

Texas Historical Commission

1511 Colorado

Austin, Texas 78701

City of Hutto

500 West Live Oak Street

Hutto, Texas 78634

$\&$

DCS Engineering, LLC

1101 South Capital of Texas Highway, Building G-100

Austin, Texas 78746

Prepared by:

Integrated Environmental Solutions, LLC

610 Elm Street, Suite 300

McKinney, Texas 75069

Cultural Resources Report

June 2020 
This page intentionally left blank 


\begin{abstract}
This report documents the substantive findings and management recommendations of a cultural resource inventory conducted by Integrated Environmental Solutions, LLC (IES) for the City of Hutto (COH) Transmission and Distribution Pumping Stations Phase I Project in the City of Hutto, Williamson County, Texas. As the $\mathrm{COH}$ is a political subdivision of the State of Texas, the $\mathrm{COH}$ is required to comply with the Antiquities Code of Texas (ACT). The goal of the survey was to locate, identify, and assess any cultural resources, which include standing buildings/structures and archeological sites that could be adversely affected by the proposed development, and to evaluate such resources for their potential eligibility for listing as a State Antiquities Landmark (SAL) or eligibility for listing in the National Register of Historic Places (NRHP).

The cultural resources inventory was conducted by Project Archeologist Anne Gibson and Archeological Field Technician Will Clow on 03 and 04 March 2020, under Texas Antiquities Permit No. 9196. The Area of Potential Effects (APE) encompasses approximately 6.63 acres (ac) and is comprised of three distinct APE areas. The Frame Switch Pumping Station (PS) is 1.2 ac in size and is located approximately 900 feet (ft) south of the intersection of Farm-to-Market Road (FM) 3349 and U.S. Highway (US) 79 midway between the City of Hutto and the City of Taylor. The Inline PS is 4.05 ac in size and is located southwest of the intersection of FM 112 and Williamson County Road (CR) 432. The Shiloh PS is 1.38 ac in size and is located approximately $1,700 \mathrm{ft}$ southwest of the intersection of FM 481 and 482.

During the survey, a newly-recorded, historic-period site (41WM1419) was documented within the APE. Based on the lack of association with historically-important individuals or events, absence of significant architectural features, the degree of prior disturbance, and lack of contextual integrity, site 41WM1419 is recommended as not eligible for listing in the NRHP or designation as SALs. In addition, four historic-age architectural resources were identified within the indirect APE during this survey.

All records will be temporarily curated at the IES McKinney office and permanently curated at the Center for Archeological Research (CAR) at the University of Texas at San Antonio (UTSA). No further work is warranted. However, if any cultural resources, other than those documented within this report, are unearthed during construction, the operators should stop construction activities, and immediately contact the project environmental representative to initiate coordination with the THC prior to resuming any construction activities.
\end{abstract}


This page intentionally left blank

COH Transmission and Distribution Pumping Stations Phase I Project Cultural Resources Survey Report

IES Project No. 04.274.008

Page ii 


\section{TABLE OF CONTENTS}

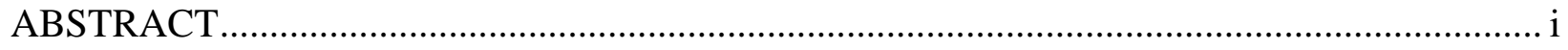

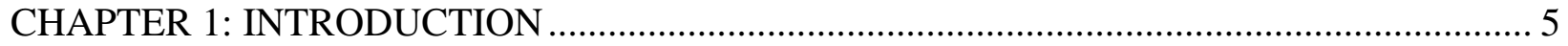

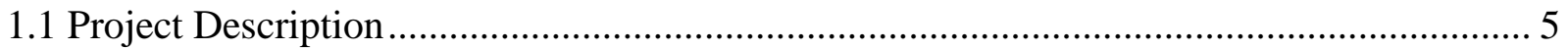

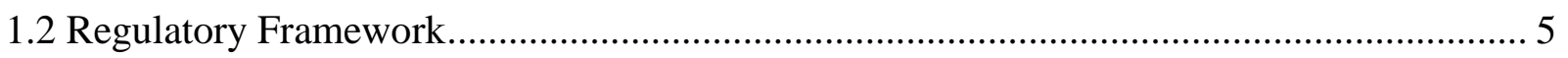

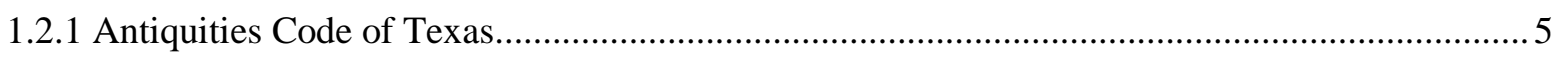

1.2.2 Section 106 of the National Historic Preservation Act .............................................................. 6

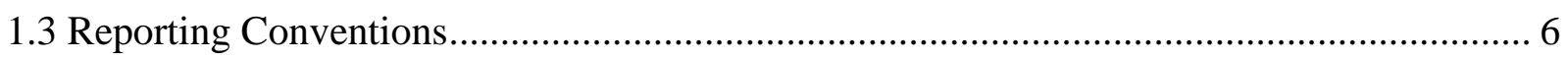

1.4 Area of Potential Effects ............................................................................................... 6

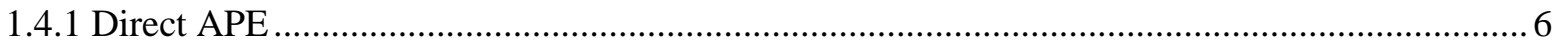

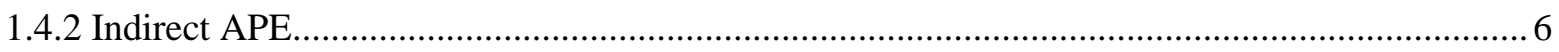

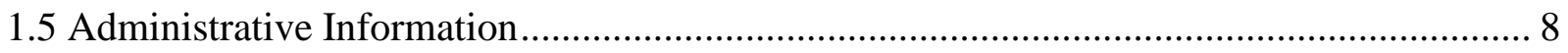

CHAPTER 2: ENVIRONMENTAL BACKGROUND …………………………….............. 9

2.1 Environmental Setting .................................................................................................. 9

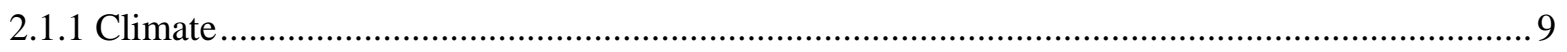

2.1.2 Topographic and Natural Setting .................................................................................... 9

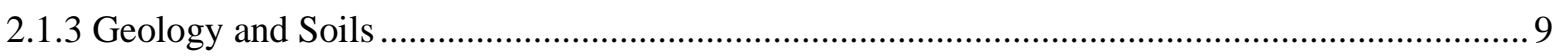

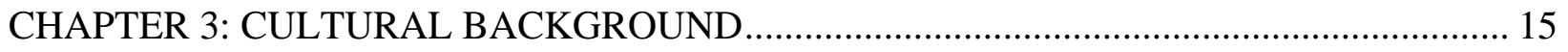

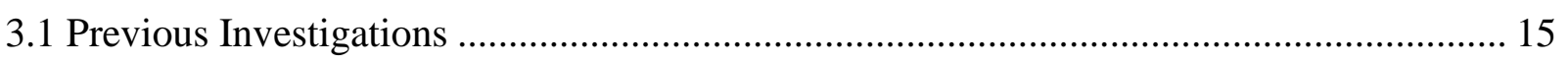

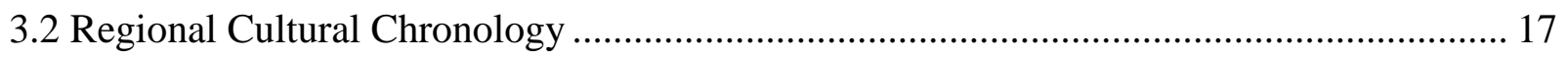

3.3 Cultural Resources Potential .................................................................................... 18

3.3.1 Disturbance Analysis .................................................................................................... 18

3.3.2 Prehistoric Resource Potential ........................................................................................ 19

3.3.3 Historic-Period Resource Potential ..................................................................................... 19

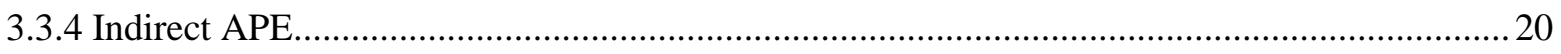

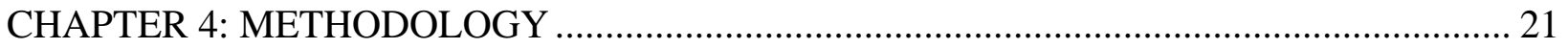

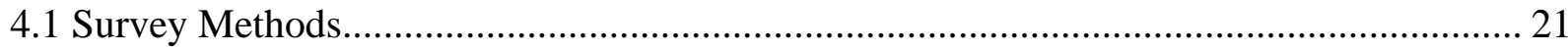

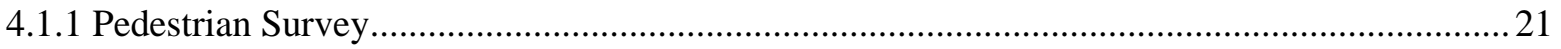

4.1.2 Shovel Testing ………………………………………………………………………. 21

4.1.3 Archeological Site Recording ........................................................................................ 21

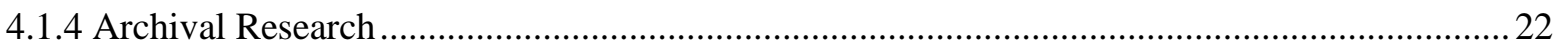

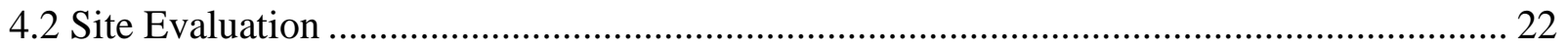

4.2.1 National Register Evaluation Criteria ...............................................................................2 22

4.2.2 State Antiquities Landmark Evaluation Criteria...................................................................2 


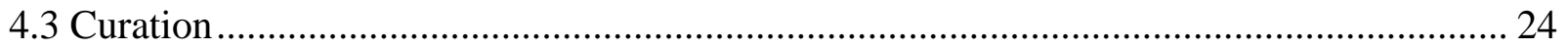

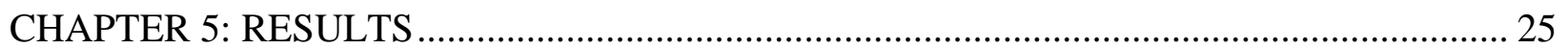

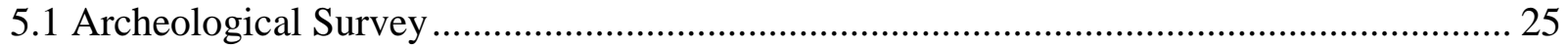

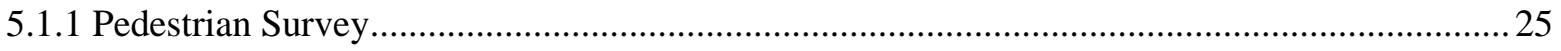

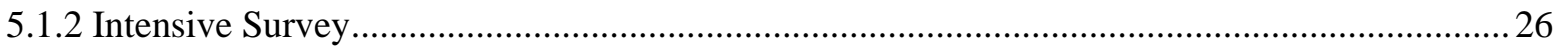

5.2 Encountered Cultural Resources .............................................................................. 28

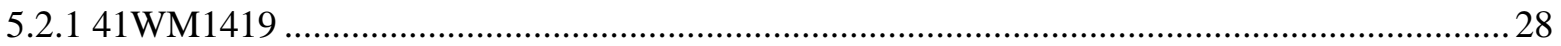

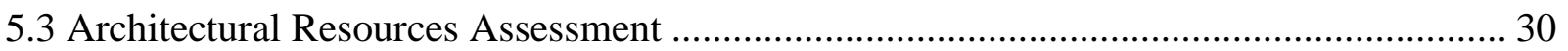

CHAPTER 6: SUMMARY AND RECOMMENDATIONS ....................................................... 33

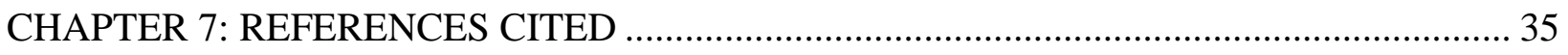

\section{LIST OF FIGURES}

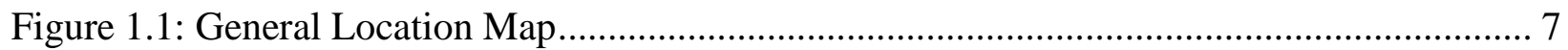

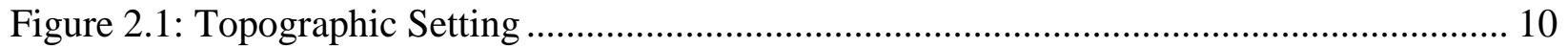

Figure 2.2: Geologic Setting ............................................................................................... 12

Figure 2.3: Soil Map Units Located Within and Adjacent to the APE......................................... 13

Figure 3.1: Previous Investigation Within 1 Mile of the APE..................................................... 16

Figure 5.1: Shovel Test Location........................................................................................ 27

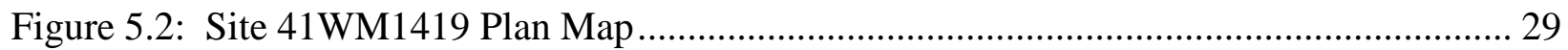

Figure 5.3: Architectural Resource Map................................................................................ 31

\section{LIST OF TABLES}

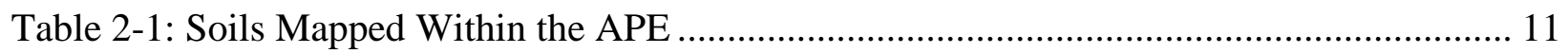

Table 3-1: Previously Recorded Archeological Sites within 1 Mi of the APE .............................. 15

Table 3-2: Previously Recorded Archeological Sites within 1 Mi of the APE ............................ 15

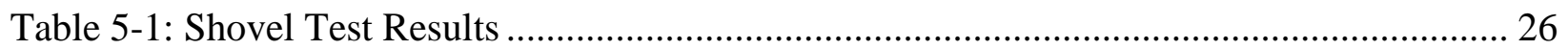

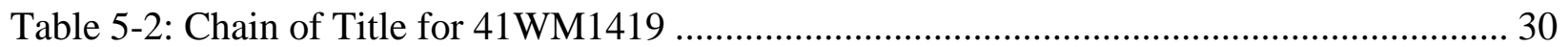

Table 6-1: Summary of NRHP Eligibility Recommendations ...................................................... 33

\section{APPENDICES}

Appendix A - Photograph Location Map and Project Photographs (Restricted Information) Appendix B - Architectural Resources Photograph Location Map and Photographs Appendix C - Archeological Site Location Map 


\section{CHAPTER 1: INTRODUCTION}

\subsection{Project Description}

This report presents the results of a cultural resources survey conducted by Integrated Environmental Solutions, LLC (IES), under contract to DCS Engineering, LLC, on behalf of City of Hutto (COH), for the proposed COH Transmission and Distribution Pumping Stations (PS) Phase I Project. This improvement project will increase the capacity of the Heart of Texas (HOT) transmission pipeline to its maximum capacity of 5.70 million gallons per day (mgd), increase the capacity of the Frame Switch PS from 4.32 mgd serving $801 \mathrm{foot}$ (ft) pressure plane (PP) to $5.70 \mathrm{mgd}$, and create a new $890 \mathrm{ft}$ PP with a dedicated 5.70 mgd PS.

The purpose of these investigations was to conduct an inventory of cultural resources (as defined by Code of Federal Regulations, Title 36, Section 800.4 [36 CFR 800.4]) present within the proposed project area or Area of Potential Effects (APE). The goal of this survey was to locate, identify, and assess archeological sites, buildings, structures, or other cultural resources within the project area that may be eligible for inclusion in the National Register of Historic Places (NRHP) or designation as State Antiquities Landmarks (SAL). This investigation was conducted in accordance with 36 CFR 60.4 and Texas Administrative Code, Title 13, Chapter 26 [13 TAC 26]), which outline the regulations for implementing Section 106 of the National Historic Preservation Act of 1966 (NHPA), as amended, and the Antiquities Code of Texas (ACT), respectively. Additionally, the project aimed to evaluate identified resources for their eligibility for inclusion in the NRHP, as per Section 106 (36 CFR 800) of the NHPA or for designation as SAL under the ACT (Texas Natural Resources Code, Title 9, Chapter 191 [9 TNRC 191]) and associated state regulations (13 TAC 26).

Prepared in accordance with the Council of Texas Archeologists (CTA 2002) guidelines, this report satisfies the NHPA Section 106 and the ACT requirements of the project. A description of the project area, pertinent regulations, environmental and historical contexts, field and analytical methods, results of the investigations, and recommendations regarding the identified cultural resources are provided in this document

\subsection{Regulatory Framework}

\subsubsection{Antiquities Code of Texas}

As the project will transpire on land owned or controlled by the $\mathrm{COH}$, which is a political subdivision of the State of Texas, the project will be subjected to the provisions of the ACT. The ACT was passed in 1969 and requires that the Texas Historical Commission (THC) staff review any action that has the potential to disturb historic and archeological sites on public land. Actions that require review under the ACT include any project that will have ground-disturbing activities on land owned or controlled by a political subdivision of the State and include easements on private property. Advanced project review by the THC is required only for undertakings with more than 5 ac or 5,000 cubic yards $\left(\mathrm{yd}^{3}\right)$ of ground disturbance. However, if the activity occurs inside a designated historic district, affects a recorded archeological site, or requires onsite investigations, the project will need to be reviewed by the THC regardless of project size. 


\subsubsection{Section 106 of the National Historic Preservation Act}

As this project will require a Section 404 of the Clean Water Act (CWA) Permit from the U.S. Army Corps of Engineers (USACE) for impacts to waters of the United States (WOUS), the project will be subject to the provisions of the NHPA of 1966, as amended. The NHPA (54 U.S. Code [USC] 300101 et seq.), specifically Section 106 of the NHPA (54 USC 306108) requires the State Historic Preservation Officer (SHPO), an official appointed in each state or territory, to administer and coordinate historic preservation activities, and to review and comment on all actions licensed by the federal government that will have an effect on properties listed in the National Register of Historic Place (NRHP), or eligible for such listing. Per 36 CFR Part 800, the federal agency responsible for overseeing the action must make a reasonable and good faith effort to identify cultural resources.

Identification, evaluation, and documentation of archeological sites shall be completed in accordance with the provisions of the Secretary of the Interior's regulatory standards, which are implemented by the THC. Archeological investigations shall be performed and documented at sufficient levels to satisfy THC requirements for determining the presence of archeologically significant properties within the APE in accordance with 13 TAC 26, which outlines the regulations for implementing the ACT. The goal of the survey will be to locate, identify, and assess any archeological sites that could be adversely affected by the proposed project, and to evaluate such resources for their potential eligibility for listing as a SAL or eligibility for listing in the NRHP.

\subsection{Reporting Conventions}

Standards for archeological methods require that measurements be recorded in metric units. For this reason, while general distances and engineering specifications are described in imperial units (e.g., inch [in], foot [ft], mile [mi], ac) within this report, archeological measurements and observations are listed in metric units (e.g., centimeter $[\mathrm{cm}]$, meter $[\mathrm{m}]$, kilometer $[\mathrm{km}]$, hectare [ha]), unless historic-period artifact or architectural elements are more appropriately recorded in imperial units.

\section{$\underline{1.4}$ Area of Potential Effects}

\subsubsection{Direct APE}

The APE encompasses approximately 6.63 ac and is comprised of three distinct APE areas. The Frame Switch PS is 1.2 ac in size and is located approximately $900 \mathrm{ft}$ south of the intersection of Farm-to-Market Road (FM) 3349 and U.S. Highway (US) 79 midway between the COH and the City of Taylor. The Inline PS is 4.05 ac in size and is located southwest of the intersection of FM 112 and Williamson County Road (CR) 432. The Shiloh PS is 1.38 ac in size and is located approximately 1,700 ft southwest of the intersection of CR 481 and 482. The APE is plotted on recent aerial photography and the Hutto 7.5-minute series U.S. Geological Survey (USGS) Quadrangle sheet (Figure 1.1).

\subsubsection{Indirect $A P E$}

As the construction of the Inline PS will impact WOUS, this project component must comply with Section 404 of the CWA and Section 106 of the NHPA, which require that indirect effects by the proposed construction of the Inline PS to historic resources be considered. As project elements will be permanently located above ground, an assessment of indirect visual impacts for this proposed pump station will be required. As such, a 200-ft area surrounding the Inline PS was evaluated for indirect effects (see Figure 1.1). No other indirect effects will result from the proposed project. 


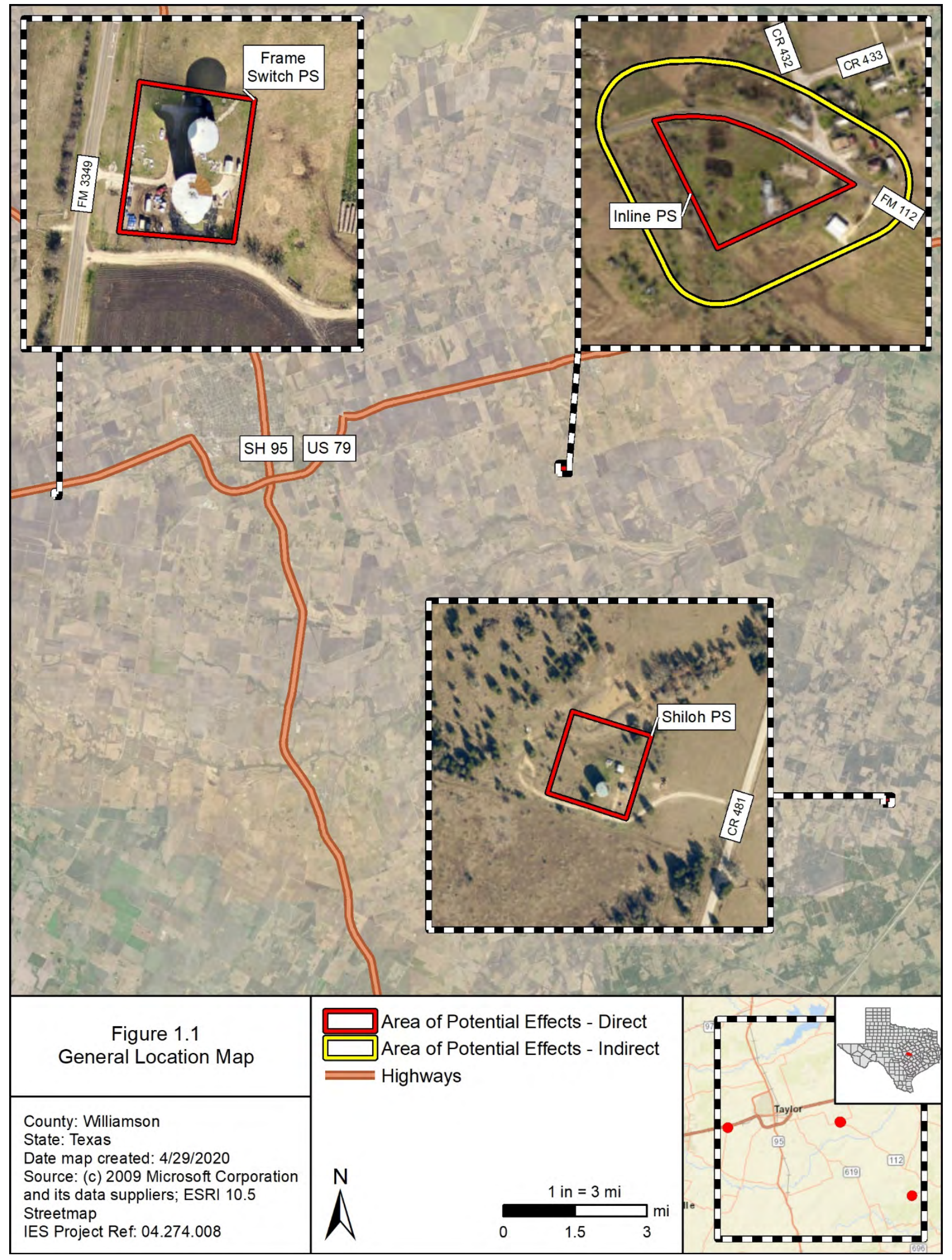

COH Transmission and Distribution Pumping Stations Phase I Project Cultural Resources Survey Report

IES Project No. 04.274.008 


\subsection{Administrative Information}

Sponsor: City of Hutto

Review Agency: THC

Principal Investigator: Jamie Vandagriff, MA, RPA

Field Crew Members: Anne Gibson, MA, RPA, Archeological Field Technician Will Clow

IES Project Number: 04.274.008

Days of Field Work: 03 and 04 March 2020

Area Surveyed: Approximately 6.63 ac

Sites Recommended as Eligible for National Register Listing Under Criteria in 36 CFR 60.4:

None

Sites Not Recommended as Eligible for National Register Listing Under Criteria in 36 CFR 60.4:

41WM1419

Curation Facility: No artifacts were collected. Field notes will be temporarily curated at IES and permanently curated at the University of Texas at San Antonio (UTSA) Center for Archeological Research (CAR). 


\section{CHAPTER 2: ENVIRONMENTAL BACKGROUND}

\section{$\underline{2.1}$ Environmental Setting}

\subsubsection{Climate}

Williamson County is in the central part of the state of Texas. This region has a humid subtropical climate and an annual rainfall averaging approximately 35 in. Approximately 60 percent of the total annual precipitation usually falls in April through September. The humid, temperate climate tends to have hot summers and mild winters with occasional cold snaps lasting no longer than two days (Werchan and Coker 1983).

\subsubsection{Topographic and Natural Setting}

The Taylor, Thrall, and Beaukiss 7.5-minute USGS topographic maps illustrates that the project area is located within the Blackland Prairie ecoregion (Figure 2.1). The Frame Switch PS and Inline PS are located on an upland terrace that is a part of the Brushy Creek watershed structure. Brushy Creek, which runs westto-east and drains into the larger Brazos River watershed, parallels Frame Switch PS and Inline PS to the south of the APE by $5 \mathrm{mi}$ and $1.5 \mathrm{mi}$, respectively. The Shiloh PS is located on an upland ridge that gently slopes to the south and west with watershed draining into Sand Branch approximately 0.5 mi to the southeast. Sand Branch is a tributary of Brushy Creek that is approximately $3.5 \mathrm{mi}$ south of the Shiloh PS.

The general topography of the project area consists of gently rolling, level terrain located on ancient terraces. The Frame Switch PS is approximately $0.10 \mathrm{mi}$ directly south of an unnamed tributary of Mustang Creek. The banks of Mustang Creek are typically wooded with invasive mesquite, oak, and juniper trees. The creek flows through flat to rolling terrain surfaced by clayey soils used predominately to grow crops (Hester 2019a). The Inline PS is $0.06 \mathrm{mi}$ east of an unnamed tributary of Brushy Creek. Brushy Creek and its tributaries have banks that are heavily wooded with mesquite and hardwood trees, and the creek flows through nearly level to gently rolling terrain surfaced by clayey and loamy soils used primarily for agriculture (Handbook of Texas Online 2019b). The Shiloh PS is approximately 0.62 mi northwest of Sand Branch which drains into the larger Middle Yegua Creek to the south. The banks of the stream are also wooded in places with post oak and other hardwood trees, and the creek flows through flat terrain surfaced by loamy and clayey soils (Handbook of Texas Online 2019c).

This region is dominated and characterized by tall and short grasses such as little bluestem (Schizachyrium scoparium), big bluestem (Andropogon gerardii), yellow Indiangrass (Sorghastrum nutans), and tall dropseed (Sporobolus asper) (Diamond and Smeins 1993). During the late 1800's and early 1900's, extensive "breaking of the prairie" occurred as farming replaced ranching. This signaled the end of the tallgrass prairie communities and very few small remnants and hay meadows remain after cotton production became incredibly widespread and wooded bottomlands along stream banks were cleared (Schmidley 2002). Most of the native prairie vegetation has been converted to cropland and non-native pasture consisting of Johnsongrass (Sorghum halepense), Bermudagrass (Cynodon dactylon), or King Ranch bluestem (Bothriochloa ischaemum). The Blackland Prairie was home to bison, pronghorn, wolves, and greater prairie chickens, but the ecosystem can longer support the diversity of animals it once did due to an almost total loss of natural habitat.

\subsubsection{Geology and Soils}

The APE is located within the Northern Blackland Prairie, which is characterized by low-relief topography containing dark, thick, plastic clay soils (Griffith et al. 2007). The Blackland Prairie owes its moniker to the thick black calcareous soils which cover the Late Cretaceous shales, marls, and chalks that underlie the prairie (Housh 2007). The Blackland Prairie ecoregion spans approximately 6.1 million ha from the Red River on the north to near San Antonio in South Texas (Eidson and Smeins 2019). The APE is located within the Taylor Blackland Prairie ecoregion. The soils in this area are typically clays of the order vertisol that formed on Cretaceous deposits (Griffith et al. 2007). 


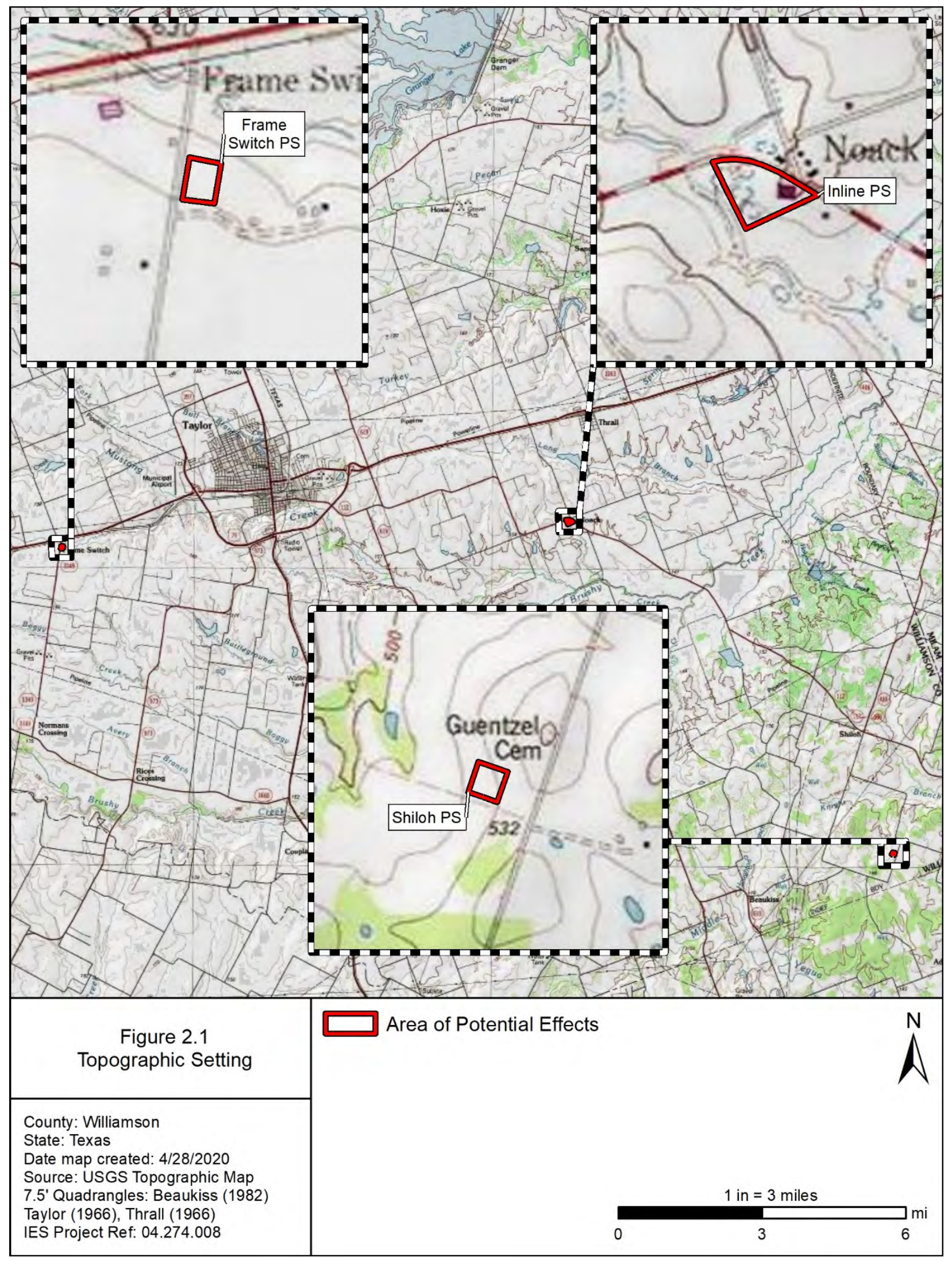

COH Transmission and Distribution Pumping Stations Phase I Project Cultural Resources Survey Report

IES Project No. 04.274.008 
Soils within the APE are underlain by the Calvert Bluff Formation (Ecb) characterized by mudstone and sandstone beds dating to the Paleocene and Eocene, the Paleocene-aged Simsboro Formation (Esb) of mostly sand, mudstone, and clay, Navarro Group and Malbrook Marl, undivided (Kknm) that is characterized by clay with variable amounts of silt and glauconite dating to the Late Cretaceous, and high gravel deposits (Qhg) which is gravel commonly exposed to the surface of Pleistocene age (Proctor et al. 1981; USGS 2020; Figure 2.2).

As shown by the Soil Survey of Williamson County, Texas, there are four soil map units within the APE (Werchan and Coker 1983). Due to the wide-ranging topographic setting of each APE location, soils vary from those typical of both in situ soil development within upland settings and alluvial deposition. Soils are summarized for the APE in Table 2.1. Soil data was viewed from the U.S. Department of Agriculture (USDA) Natural Resources Conservation Service (NRCS) Web Soil Survey (USDA 2020; Figure 2.3).

Table 2-1: Soils Mapped Within the APE

\begin{tabular}{||l|c||}
\hline \multicolumn{1}{|c||}{ Soil Map Unit Description } & $\begin{array}{c}\text { Approximate } \\
\text { Percentage of APE }\end{array}$ \\
\hline \hline $\begin{array}{l}\text { BrB - Branyon clay, } \mathbf{1} \text { to } 3 \text { percent slopes - This component is described as clay located on stream terraces. } \\
\text { Depth to bedrock or a root restrictive layer is more than } 80 \text { in }(203 \mathrm{~cm}) \text {. The natural drainage class is moderately } \\
\text { well drained. Typical Bk subsoil horizon depth is } 12 \text { to } 72 \text { in }(30 \text { to } 182 \mathrm{~cm})\end{array}$ & 18.1 \\
\hline $\begin{array}{l}\text { HeC } 2 \text { - Heiden clay, } \mathbf{3} \text { to } 5 \text { percent slopes, eroded }- \text { This component is described as clay located on ridges. } \\
\text { Depth to densic material is } 40 \text { to } 65 \text { in }(102 \text { to } 165 \mathrm{~cm}) . \text { The natural drainage classis well drained. Typical Bk } \\
\text { subsoil horizon depth is } 6 \text { to } 18 \text { in }(15 \text { to } 45 \mathrm{~cm}) .\end{array}$ & 61.1 \\
\hline $\begin{array}{l}\text { Rbtf - Robco-Tanglewood complex, } \mathbf{1} \text { to } \mathbf{5} \text { percent slopes }- \text { This component is described as loamy fine sand } \\
\text { located on ridges. Depth to bedrock or a root restrictive layer is more than } 80 \text { in }(203 \mathrm{~cm}) \text {. The natural drainage } \\
\text { class is moderately well drained. Typical Bt subsoil horizon depth is } 11 \text { to } 26 \text { in }(28 \text { to } 66 \text { cm) }\end{array}$ & 20.7 \\
\hline $\begin{array}{l}\text { TnA - Tinn clay, } \mathbf{0} \text { to } \mathbf{1} \text { percent slopes, frequently flooded }- \text { This component is described as clay located in } \\
\text { flood plains. Depth to bedrock or a root restrictive layer is more than } 80 \text { in }(203 \mathrm{~cm}) . \text { The natural drainage class } \\
\text { is moderately well drained. Typical Bs subsoil horizon depth is } 17 \text { to } 57 \text { in }(43 \text { to } 145 \mathrm{~cm})\end{array}$ & $<0.1$ \\
\hline
\end{tabular}




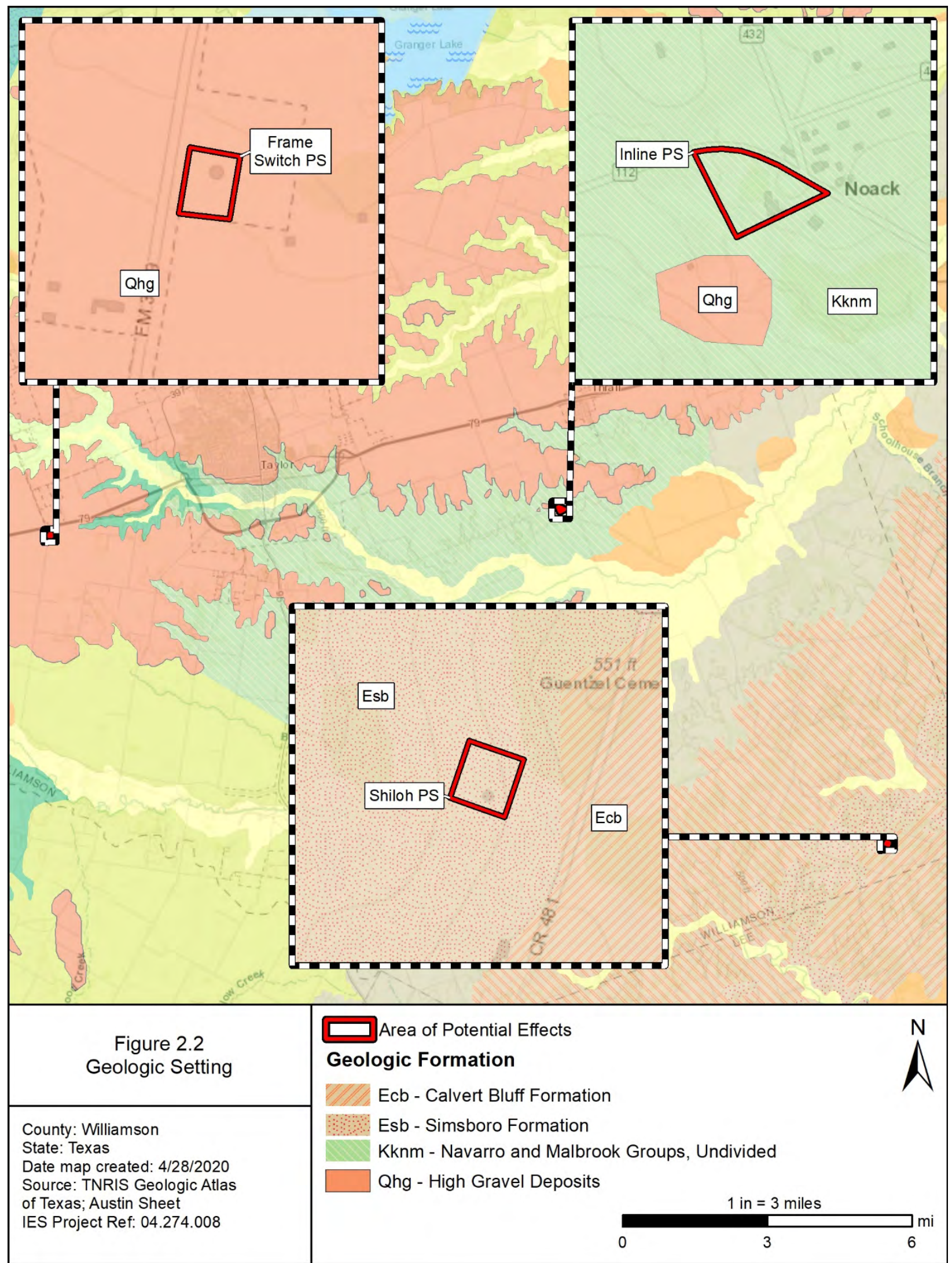

COH Transmission and Distribution Pumping Stations Phase I Project Cultural Resources Survey Report 


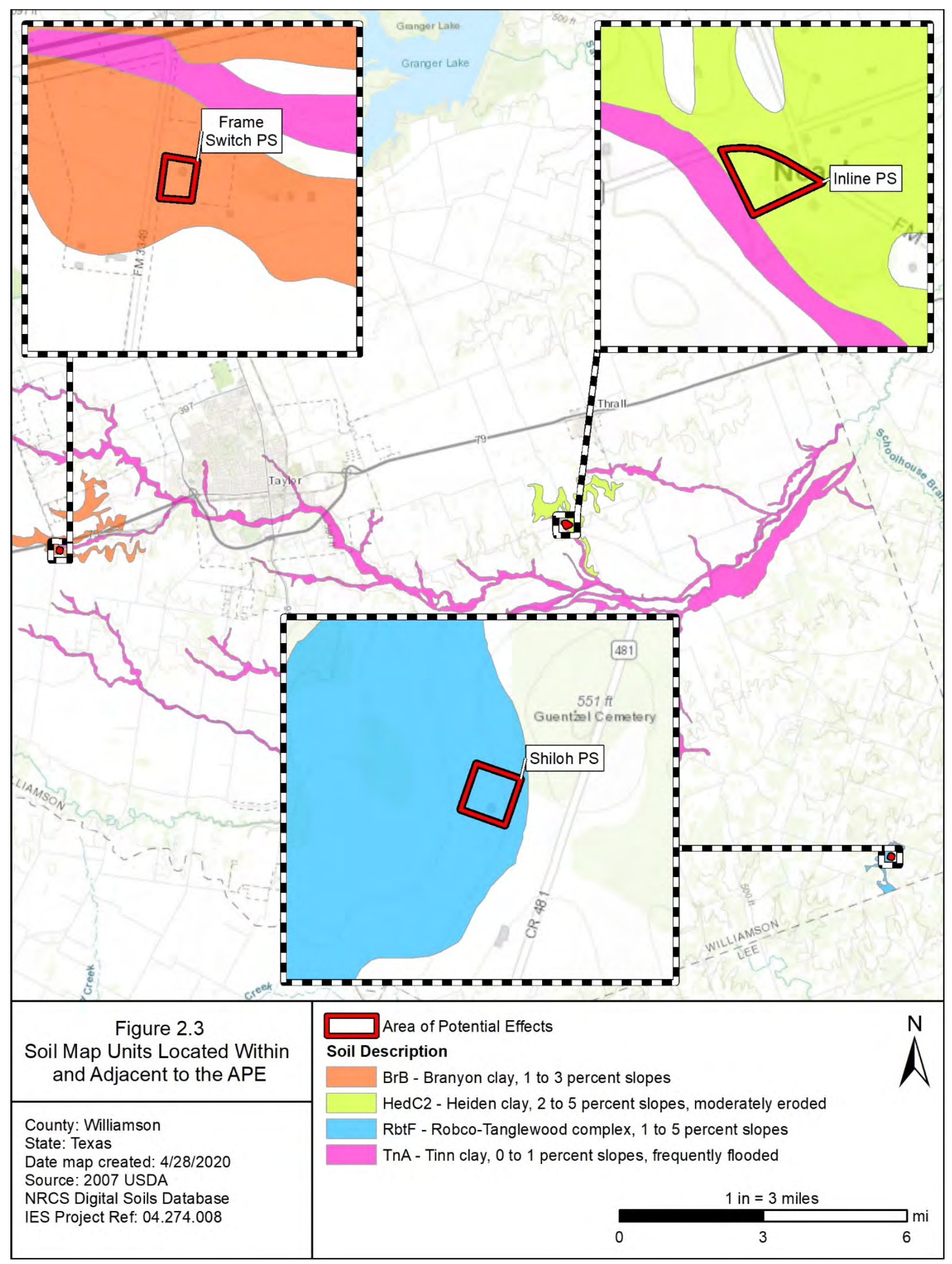

COH Transmission and Distribution Pumping Stations Phase I Project Cultural Resources Survey Report 
This page intentionally left blank

COH Transmission and Distribution Pumping Stations Phase I Project Cultural Resources Survey Report

IES Project No. 04.274 .008

Page 14 


\section{CHAPTER 3: CULTURAL BACKGROUND}

\subsection{Previous Investigations}

A file search within the Texas Archeological Sites Atlas (TASA) and the Texas Historic Sites Atlas (THSA) electronic databases, maintained by the THC, identified that there are two previously recorded archeological sites, two cemeteries, and one historical marker located within $1 \mathrm{mi}$ of the proposed APE (TASA 2020; THSA 2020; Table 3.1). Site 41WM242 is located approximately $0.61 \mathrm{mi}$ northeast of the Inline PS, and site 41WM767 is located approximately $0.43 \mathrm{mi}$ northwest of the Frame Switch PS. Based on illustrations and dimensions provided in the TASA database, neither site extends into the APE. The Texas Archeological Research Laboratory (TARL) was not contacted due to the distance of these sites from the APE and the low to negligible potential that these sites would be encountered during the current survey. The reports for two previously conducted surveys in the proximity of 41WM767 were also reviewed, and neither report contained additional information regarding the site nor was the site encountered within those previous survey areas (Koszarek 2017; Owens 2011). A third survey was conducted nearby, but no information was available regarding the 1976 survey via the TASA. No other information was available via the TASA regarding sites 41WM242 or 41WM767.

Table 3-1: Previously Recorded Archeological Sites within $1 \mathrm{Mi}$ of the APE

\begin{tabular}{||c|c|c|c|c|c|c|c||}
\hline $\begin{array}{c}\text { Site } \\
\text { Trinomial }\end{array}$ & Time Period & Site Type & Site Size & Depth Extent & $\begin{array}{c}\text { Cultural } \\
\text { Materials }\end{array}$ & $\begin{array}{c}\text { Topographic } \\
\text { Setting }\end{array}$ & $\begin{array}{c}\text { NRHP } \\
\text { Determination }\end{array}$ \\
\hline \hline $41 \mathrm{WM} 242$ & Unknown & Campsite & Unknown & Unknown & Unknown & Upland terrace & Unknown \\
\hline $41 \mathrm{WM} 767$ & Unknown & Unknown & Unknown & Unknown & Unknown & Upland terrace & Unknown \\
\hline \hline
\end{tabular}

The TASA database illustrates that three archeological surveys have been conducted within 1 mi of the APE (Table 3.2; Figure 3.1). One of these surveys was conducted by HDR Engineering, Inc. (HDR), under contract to Brown \& Gay Engineers (BGE), on behalf of Williamson County in 2017, and was conducted along CR 101 for $3.8 \mathrm{mi}$ and terminated at the intersection with US 79. A second survey, at the intersection of FM 1660 and US 79, was conducted by Horizon Environmental Services, Inc. (Horizon), on behalf of Williamson County in 2011. A linear survey along FM 3349, directly adjacent to the Frame Switch PS, was conducted in 1976 for the Texas Department of Highways and Public Transportation (TDHPT). No further information was available regarding this survey.

Table 3-2: Previously Recorded Archeological Sites within $1 \mathrm{Mi}$ of the APE

\begin{tabular}{||c|c|c|c|c|c||}
\hline Agency & $\begin{array}{c}\text { ACT } \\
\text { Permit No. }\end{array}$ & $\begin{array}{c}\text { Firm/ } \\
\text { Institution }\end{array}$ & Date & $\begin{array}{c}\text { Survey } \\
\text { Type }\end{array}$ & Location (Approximate) \\
\hline \hline $\begin{array}{c}\text { Texas Department of Highways and } \\
\text { Public Transportation (nka Texas } \\
\text { Department of Transportation [TxDOT]) }\end{array}$ & N/A & Unknown & 1976 & Linear & Adjacent to the Frame Switch PS \\
\hline Williamson County, TxDOT & 5788 & $\begin{array}{c}\text { HNTB, } \\
\text { Horizon }\end{array}$ & 2011 & Area & 0.26 mi northwest of Frame Switch PS \\
\hline Williamson County & 7694 & HDR & 2017 & Linear & 0.19 mi north of Frame Switch PS \\
\hline
\end{tabular}

One cemetery, Noack Christ Church (also known as Zieschang Cemetery), is located $0.40 \mathrm{mi}$ south of the Inline PS. The cemetery was established and is maintained by the Christ Lutheran Church of Noack, which is within view of the cemetery approximately a mile away to the northwest. The one historical marker (\#18549) identified within $1 \mathrm{mi}$ of the APE is associated with the Christ Lutheran Church. The present church building was completed in 1916 and is still in use. A second cemetery, Guentzel Cemetery, is located approximately $425 \mathrm{ft}$ northeast of the Shiloh PS. There are only eight headstones in the cemetery. 


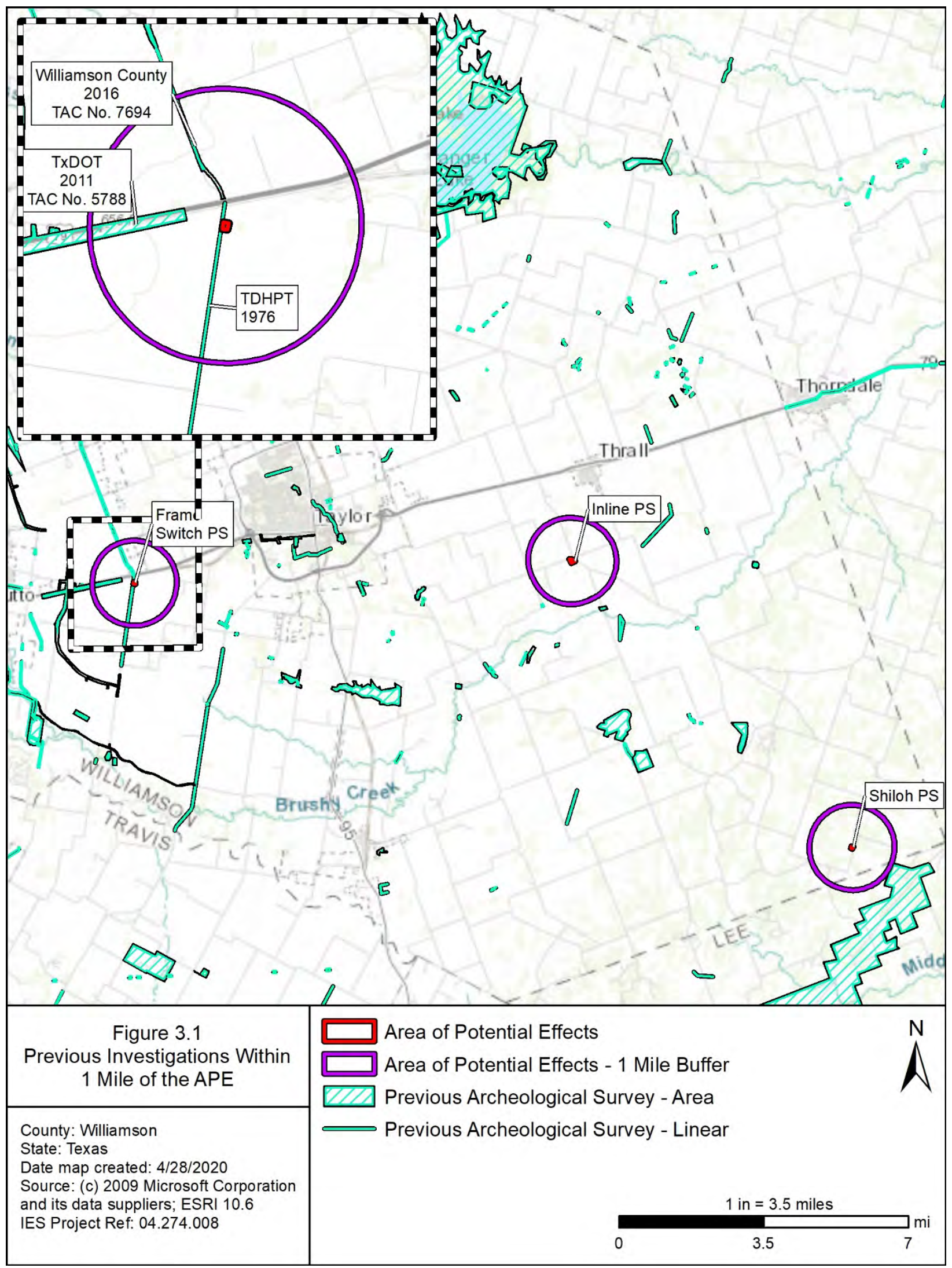

COH Transmission and Distribution Pumping Stations Phase I Project Cultural Resources Survey Report

IES Project No. 04.274.008 


\subsection{Regional Cultural Chronology}

The Central Texas region, including Williamson County, has supported people for thousands of years. Archeological evidence suggests that hunting and gathering populations established themselves in Central Texas as early as 10,000 years ago. The earliest, widespread prehistoric occupation within the region pertains to highly nomadic big game hunting groups known as Paleoindians. The Paleoindian period has been identified as occurring between 11,500 and 8,800 years before present (BP). Like many prehistoric periods, the Paleoindian epoch was defined by type of tool manufacturing and subsistence. Paleoindians are known for the large lanceolate shaped lithic tools and prismatic blade production that were used to hunt megafauna (Collins 2004).

As the climatic setting continued to warm, prehistoric groups were required to alter their tool and subsistence strategies to survive. The current archeological record indicates that the Archaic Period in Central Texas ranged from 8,880 to 1,200 BP. This period is commonly divided into three broad subperiods (Earl, Middle, and Late). The reduction of Archaic projectile points observed during this period relates to the change in hunting technology and the use of dart point projectiles thrown using an atlatl. Additionally, increased quantities of burned rock middens dating to this period suggest continued reuse of key campsites and a steadily increasing population density.

The Late Prehistoric period, ranging between 1,200 and 400 BP, is marked by further technological changes. One of the hallmark technological shifts during this period was the use of bows and arrows that resulted in smaller projectile point production. Other changes in technology pertained to the development of refined pottery. By the $14^{\text {th }}$ century, tribes of Tonkawa and Lipan Apache were well established in Central Texas (Collins 2004; Smyrl 2010a).

The Historic Period in Texas can be divided into two sub-periods: the Protohistoric and Historic. The Protohistoric (ca. A.D. 1528-1700) is ushered by the venture into Central and South Texas by Spanish explorer Cabeza de Vaca in 1528. Archeological sites dated to this sub-period contain a mix of both European and traditional Native American artifacts. These sites provide a glimpse into what Spanish and Native American interaction was like prior to the establishment of Spanish missions in the $18^{\text {th }}$ century (Hester 1995). By the early 1700s, the Spanish had sought a route between San Antonio and the Spanish missions in East Texas that would be drier routes as opposed to the southerly Camino Real. This new route passed through Williamson County along Brushy Creek and the San Gabriel River and was called Camino de Arriba. The San Xavier missions, which were founded in the mid- $18^{\text {th }}$ century and occupied a series of sites along the San Gabriel River, were just across the eastern border of Williamson County in present-day Milam County.

During the early days of the Republic of Texas, Anglo settlers moved into the area. By 1848 there were at least 250 settlers in what was then Milam County, and earlier that same year 107 of the them signed a petition to organize a new county (Odintz 2019). The Texas Legislature established Williamson County on March 13, 1848, and it was named after prominent judge and solider Robert M. Williamson. In 1850, the county had a population of 1,500 inhabitants. By the time of the American Civil War, the population had increased to 4,500 .

For much its history, the economy of Williamson County was supported by agriculture and ranching. The main crops of the county were cotton and corn until the Great Depression, after which sorghum and wheat increased in production. The cattle, sheep, and poultry industries have also played a significant role in the county's economy. During the $20^{\text {th }}$ century, increases in population and the growth of manufacturing led to changes social and economic changes. Although agriculture still plays an important role, high-tech business and manufacturing industries have become major contributors to the county's economy. The spread of urbanization from the nearby City of Austin has resulted in the population growing from 37,000 citizens in 1970 to 489,000 inhabitants in 2014. (Odintz 2019) 


\subsection{Cultural Resources Potential}

In addition to the TASA review, several additional sources were referenced to determine the overall potential for encountering cultural resources within the APE. These sources included the Soil Survey of Williamson County, Texas, the Geologic Atlas of Texas, Austin Sheet, USGS topographic maps, the NRCS digital soil database for Williamson County, the Texas Department of Transportation (TxDOT) Potential Archeological Liability Map (PALM) for Austin, the 1936 Texas State Highway Department Map for Williamson County, the Texas Historic Overlay (THO) georeferenced maps, and both past and current aerial photography.

The TxDOT PALM discussed in this chapter examines "the character and classification of the soils and assesses the shallow and deep geoarcheological potential or the likelihood that soil could contain buried cultural materials in reasonable context (i.e., historic/recent disturbances, landscape setting, and soils data) for each soil series" (Abbott 2011:161). The TxDOT PALM model identifies where sites are likely to be preserved in a reasonable context versus indicating where sites are likely to exist (Abbott 2001:154, 2011:179). As the resolution of the PALM is appropriate to the scale of landform mapping (approximately $1: 24,000)$, any analysis of the data beyond the scale of mapping can result in a misunderstanding of the detail of mapping (Abbott 2011:175). Due to the more detailed evaluation required to accurately evaluate the potential for presence of cultural resources and the development of appropriate field methodology (typically at the 1:7,000 scale or less), the cultural resources potential evaluation presented in this scope includes an assessment of the PALM results at a more detailed level to determine if the APE has retained a reasonable degree of contextual integrity as assumed by the PALM model. A reasonable context is evaluated through a review of historical and modern aerial photographs to ascertain the level of previous ground disturbance that has transpired within a given area. The field methods for assessing for potential archeological sites is presented in the Chapter $\mathbf{4}$ of this report.

\subsubsection{Disturbance Analysis}

During the background review, it was determined that ground-disturbing activities related to past land use have transpired within the APE. The $\mathrm{COH}$ and the surrounding area has been occupied since 1877 and has been heavily impacted by road construction, agricultural farming practices, and construction of associated pipelines for the wastewater treatment facilities. Historical aerial photographs indicate that properties within and adjacent to the APE were primarily used for agricultural purposes from as early as 1934 .

\subsubsection{Frame Switch PS}

Within the Frame Switch PS, the entire APE has been heavily disturbed by the previous activities associated with the construction of the old PS including the construction of gravel driveways, fencing, water towers, and various other structures. Prior to construction of the PS, the land had been used for agricultural purposes as far back as 1963.

\subsubsection{Inline PS}

Historical maps and aerial photographs indicate the APE was disturbed by the construction of multiple buildings and excavation of at least three ponds in the western half of the APE. Within the Inline PS APE there is one extant structure that dates between 1981 and 1995. The structure was built as an event/party barn as it is furnished with multiple bars, a stage, and several spacious rooms to accommodate large events. A house once stood northeast of the barn. The house and associated small structures are present on aerial photographs dating to 1963. The house was leveled, except the cement foundation, sometime between 2004 and 2008.

\subsubsection{Shiloh PS}

The Shiloh PS has been subjected to major disturbances through the construction of the PS, gravel driveways, and associated reservoir which was built sometime between 2004 and 2008. Prior to the 
construction of the PS, the land was used as pasture. Based on aerial photographs, it does not appear as if it has been plowed from as early as 1981 .

\subsubsection{Prehistoric Resource Potential}

\subsubsection{Frame Switch PS}

Within vicinity to the APE, very few surveys other than linear projects have been previously conducted. No prehistoric sites have been identified near the Frame Switch PS. Prior to 2004, the land within the Frame Switch PS was primarily used as pasture based on aerial photographs. Although the APE is in proximity to an unnamed tributary of Mustang Creek, which increases the potential for prehistoric deposits, the area has been heavily disturbed by the construction of the PS (built between 1995 and 2004), associated grading, gravel driveways, and fencing which caused significant ground disturbance within the APE. The TxDOT PALM for the Austin District indicates that the west side of Frame Switch PS was considered to have moderate potential for shallow and deeply buried cultural deposits within a reasonable context; however, due to the previous ground disturbances, the APE was not considered to contain a reasonable context and more likely exhibits a low to negligible potential for prehistoric archeological resources.

\subsubsection{Inline PS}

Only one professional archeological survey has been conducted near the proposed Inline PS project area. There are previously recorded prehistoric sites located within the vicinity of the APE; however, they are mainly clustered around the banks and floodplains of Brushy Creek more than $1 \mathrm{mi}$ to the south. An unnamed tributary of Brushy Creek runs adjacent to the western APE boundary, which increases the potential for encountering prehistoric cultural materials. The TxDOT PALM illustrated that approximately 95 percent of the Inline PS contained a low to moderate potential for shallow to deeply buried cultural deposits within in a reasonable context. The remaining 5 percent contained a negligible potential. For these reasons, the Inline PS was considered to possess a reasonable context and therefore considered to contain a negligible to moderate potential.

\subsubsection{Shiloh PS}

The Shiloh PS is located on a high upland terrace, which lacks extensive soil deposition, void of any nearby natural water sources. Prior to 2008, the APE was unused or purposed for livestock grazing. By February 2008, a PS, water tower, access road, security fence, and other outbuildings were constructed and occupies approximately 36 percent of the APE. In addition, a stock pond was created that overlaps the northern boundary of the APE. The TxDOT PALM illustrated nearly the entirety of the APE was within a low probability setting for shallow to deeply buried cultural deposits within a reasonable context. However, a small section of the southeast corner had moderate potential for shallow and low potential for deeply buried cultural deposits. Due to the previous ground disturbances associated with the construction of the existing pump station and stock pond the vast majority of the APE was not considered to contain a reasonable context and more likely exhibits a low to negligible potential for prehistoric archeological resources.

\subsubsection{Historic-Period Resource Potential}

Historic-period resources within Central Texas are primarily related to farmsteads, houses, and associated outbuildings and structures that date from the mid $-19^{\text {th }}$ to the mid- $20^{\text {th }}$ centuries. Typically, these types of resources are located along old roadways, but can be located along railroads, streams, and open pastures. Although determining the presence of the earliest of these buildings and structures is problematic, maps depicting these features in the vicinity of the APE are available as early as 1934.

\subsubsection{Frame Switch PS}

Based on a review of historical maps and aerial photographs, the Frame Switch PS was used for agricultural purposes prior to the construction of the PS. No historic-age resources were identified on aerial photographs or historical maps within the Frame Switch PS APE from as early as 1936. Two homesteads were identified 
near the APE, but it was unlikely that any historic-age resources or artifacts associated with these homesteads would be encountered during this survey.

\subsubsection{Inline PS}

The Inline PS had high potential for containing historic-age artifacts associated with a non-extant building that was leveled between 2004 and 2008. According to archival resources, this building was likely associated with the Zieschang Bar and Café, which burned down in 1969 and was rebuilt the following year ("Little Noack" 1982). The foundation for the bar is still present based on current aerial photography from 2018. The building is present on USDA soil maps dating from as early as 1934 . According to Williamson County Deed Record Volume 200, Page 403 dating to 1921, the original 4.3 ac property contained a cotton gin known as the Noack Gin. In 1964, the property contained the Noack Gin, the Noack Bar, the Noack Store, and two residences (Williamson County Deed Record Volume 471, Page 239). Recent aerial photographs indicate the only structure still standing within the APE is a barn constructed between 1981 and 1995.

\subsubsection{Shiloh PS}

Within the Shiloh PS project area, one homestead, dating as early as 1950, was identified on USGS topographic maps as being located $0.14 \mathrm{mi}$ from the APE. Subsequently, it was concluded that there was negligible potential for encountering historic-age resources within the Shiloh PS.

\subsubsection{Indirect APE}

Through background research, it was determined that the indirect APE contained at least four buildings and structures of historic age (i.e. greater than 45 years old). These resources include houses and businesses within the community of Noack, which was established in 1870 as a settlement then known as Hochkirk (Scarbrough 2016). According to the Williamson County Appraisal District parcel data and historical maps, all identified resources were built in the $20^{\text {th }}$ century. 


\section{CHAPTER 4: METHODOLOGY}

The archeological inventory for the $\mathrm{COH}$ Transmission and Distribution Pumping Stations Phase I Project was conducted on 03 and 04 March 2020 The methods and density of excavating shovel test met the minimum requirements for field tactics stipulated by the THC and CTA Archeological Survey Standards for Texas. Prior to field work, the IES staff conducted an historical and archeological records search to determine what cultural resources have been recorded within the APE and within 1 mi radius of the APE. This information was detailed in Chapter 3. Additionally, IES staff reviewed ecological, geological, and soils data, as well as historic and recent topographic maps and aerial photography.

\subsection{Survey Methods}

\subsubsection{Pedestrian Survey}

The pedestrian survey consisted of visual examination of the ground surface and existing subsurface exposures for evidence of archeological sites within the survey area. The pedestrian survey was conducted in a multiple transect scheme, which was implemented across the entire survey area. Transects were spaced at 30-m intervals generally orientated in northeast-to-southwest and northwest-to-southeast directions. Areas displaying high levels of modern ground disturbance, frequent inundation, and slopes greater than 30 percent were photographed to document the lack of potential to preserve intact archeological deposits. This pedestrian survey was supplemented by the excavation of shovel tests to locate and document subsurface archeological deposits.

\subsubsection{Shovel Testing}

In areas with potential for archeological materials, shovel tests were excavated to $80 \mathrm{~cm}$ or the bottom of culturally sterile deposits, whichever is encountered first. Each shovel test was $30 \mathrm{~cm}$ in diameter and was hand excavated in natural stratigraphic levels not exceeding $20 \mathrm{~cm}$ in thickness. Excavated soil was screened using $1 / 4$-in hardware cloth to test for the presence of buried cultural material. All tests were recorded on maps and plotted using hand-held Global Positioning System (GPS) units. Investigators documented the results of each test on standardized shovel test forms. Shovel test numbers varied based on the amount of disturbance, exposed bedrock or culturally sterile soil, ground visibility, and steep slope present within the APE, or if archeological site(s) were encountered. All positive shovel tests, cultural features, and other site data was geospatially recorded using Trimble Geo XT hand-held GPS unit.

\subsubsection{Archeological Site Recording}

An archeological site is typically considered to be a spatially discrete area containing cultural resources. The recognition of a "site" is therefore contingent on the basis of content and extent. Content may refer to artifacts or cultural features encountered in surface or subsurface contexts, architectural elements, or other manifestations of past human activity. The extent of a site is based on the vertical and horizontal spatial arrangement of these cultural remains. For surficial materials, a site is defined as five or more artifacts of at least two different materials or functional classes located within the same vicinity (typically a 400 square $\mathrm{m}\left[\mathrm{m}^{2} ; 0.1-\mathrm{ac}\right]$ area) or at least one cultural feature. The extent of the surface artifacts and cultural features are then defined as the site boundary. When artifacts or features are encountered in buried contexts, a site is defined within the extent of the culturally positive excavations. In cases where an excavated survey sampling location (i.e., shovel test) yields cultural materials, additional delineation excavations are conducted to define the boundary of the site. The spatial extent of the site is defined within the extent of positive excavations. Archeological sites may also be defined within the extent of surface artifacts or features and culturally positive excavations when both are present. No less than six shovel tests are used to delineate a site.

Cultural remains, meeting these criteria, are designated as a site, recorded on a Texas Archeological Site Data Form, and submitted to TARL to be included in the TASA database. Conversely, discovery of cultural 
materials that do not meet these criteria are considered isolated occurrences of past human activity and are simply documented by location and content. Modern materials and features (i.e., less than 50 years old) are not considered sites and are documented by location and content. Depending on depositional integrity and cultural content, archeological sites can be eligible for inclusion in the NRHP or for designation as SALs. Cultural isolates and modern features are not eligible for inclusion in the NRHP or for designation as SALs because of their failure to meet the site definition and their inability to contribute important information to the understanding of history or prehistory.

\subsubsection{Archival Research}

Historic maps and aerial photographs encompassing the APE were reviewed to determine the locations of historic-age (i.e., greater than 50 years old) structures. A deed title research was conducted for historic-age archeological resources identified within the APE. The purpose was to identify historically notable persons that were possibly associated with each resource. Initial research was carried out by examining deed and land title records through the Williamson County Appraisal District and the Williamson County Clerk's Office (WCCO). The historic significance of identified persons associated with each resource were also researched using The Handbook of Texas Online database, genealogical websites, and various local history publications.

\section{$\underline{4.2}$ Site Evaluation}

Each identified archeological site was plotted on the appropriate 7.5-minute USGS topographic map and a scaled site map was prepared for each site. Field data were processed to evaluate site significance and potential eligibility for inclusion in the NRHP and designation as a SAL. When applicable, a variety of data were used to assess site significance including temporal period, artifact density, artifact variety, feature density, feature variety, feature preservation, stratigraphic integrity, and the magnitude of previous disturbance.

\subsubsection{National Register Evaluation Criteria}

The assessment of significance of a cultural resource is based on federal guidelines and regulations. The criteria for evaluating resources for inclusion in the NRHP are codified under the authority of the NHPA, as amended (36 CFR 60.4 [a-d]), and the Advisory Council on Historic Preservation (ACHP) has set forth guidelines to use in determining site eligibility. Federal regulations indicate that " $[\mathrm{t}] \mathrm{Ae}$ term 'eligible for inclusion in the National Register' includes both resources formally determined as such by the Secretary of the Interior and all other properties that meet National Register listing criteria” (36 CFR 800.2[e]). Based on ACHP guidelines, any cultural resource that is included in or eligible for inclusion in the NRHP is a historic property.

Subsequent to the identification of relevant historical themes and related research questions, four criteria for eligibility are applied. The quality of significance in American history, architecture, archeology, engineering, and culture is present in districts, sites, buildings, structures, and objects that possess integrity of location, design, setting, material, workmanship, feeling, and association and:

\footnotetext{
Criterion A: that are associated with events that have made a significant contribution to the broad patterns of our history; or

Criterion B: that are association with the lives of persons significant in our past; or

Criterion C: that embody the distinctive characteristics of a type, period, or method of construction, or that represent the work of a master, or that possess high artistic values, or that represent a significant and distinguishable entity whose components may lack individual distinction; or

Criterion D: that have yielded, or may be likely to yield, information important in prehistory or history [36 CFR 60.4(a-d)].
} 
The principal objective is to determine whether a cultural resource possesses the potential to contribute to one or more of the above-defined criteria. Adequate information regarding site function, context, and chronological placement from both archeological and, if appropriate, historical perspectives is essential for cultural resources investigations. Because research questions vary as a result of geography, temporal period, and project design, determination of site context and chronological placement of cultural resources is a particularly important objective during the inventory and evaluation processes. Criterion $\mathrm{D}$ is generally associated with prehistoric, but also historic-era, archeological sites. Criteria A, B, and C typically reflect association with historic-era resources, rarely with prehistoric sites. The objective of the current project was to locate and define both the horizontal and vertical extents of any cultural resources, document and describe those resources, and then, when adequate data were present, evaluate each for NRHP eligibility.

\subsubsection{State Antiquities Landmark Evaluation Criteria}

For purposes of implementing the ACT, the THC is the statutorily created body responsible for designating resources as SALs (9 TNRC 191). A SAL is an archeological site, archeological collection, ruin, building, structure, cultural landscape, site, engineering feature, monument or other object, or district that is eligible to be designated as a landmark or is already officially designated as a landmark. The State of Texas considers all publicly-owned archeological sites and historic buildings and structures to have some intrinsic historic value, and the ACT provides some level of protection for those sites, buildings, or structures regardless of their size, character, or ability to currently yield data that will contribute important information regarding the history or prehistory of Texas. Additionally, these publicly-owned archeological sites and historic structures are protected from vandalism, or other actions meant to take, alter, or destroy them, and information directly related to the specific location of archeological sites is restricted from open records requests. However, not all cultural resources are equally significant to the history and prehistory of Texas. Some archeological sites may not possess research value sufficient to warrant long-term preservation or investigations beyond survey-level documentation, and some historic buildings and structures retain minimal integrity due to damage or deterioration. Therefore, the issue of whether cultural resources are significant and warrant preservation, and/or further research (such as archeological testing and data recovery level investigations), is addressed through official landmark designation, permit issuance, and rules associated with enforcement of the ACT. Archeological sites and historic structures on lands belonging to state agencies or political subdivisions of the State of Texas are eligible to be designated as landmarks (9 TNRC 191.091 and 191.092). Also protected, under 9 TNRC 191.094, are specially designated landmarks on private property.

Under the ACT at the state level, archeological sites may be considered significant and be recognized or designated as a SAL. The THC uses one or more of the following criteria when assessing the appropriateness of official landmark designation, and/or the need for further investigations under the ACT permit process:

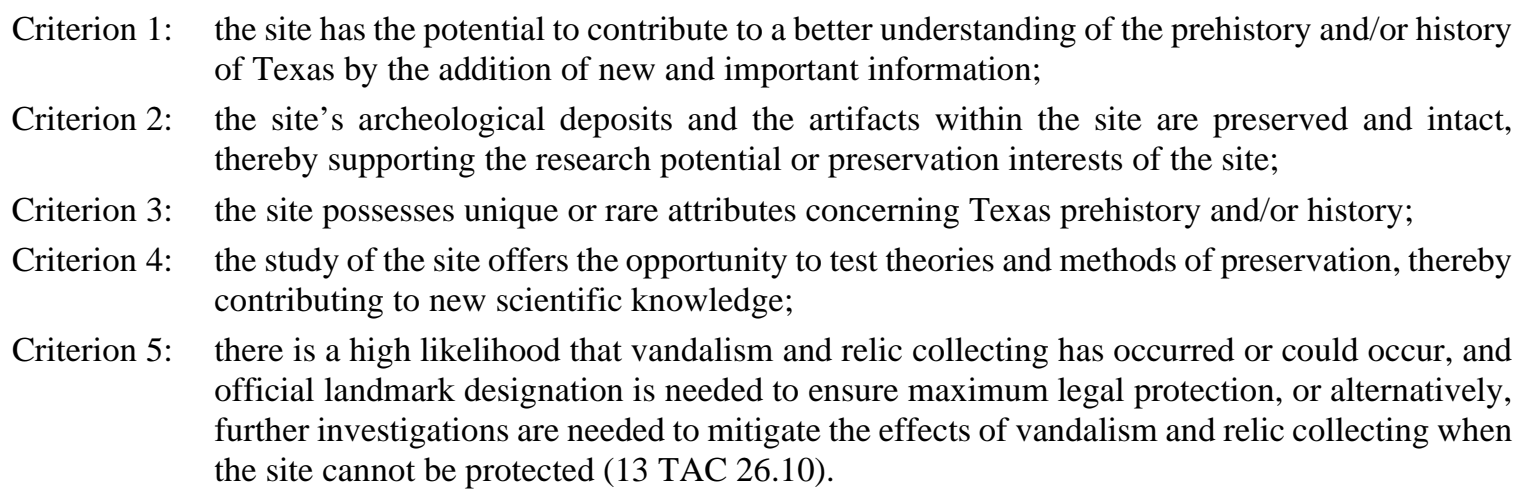

Buildings, structures, cultural landscapes, and non-archeological sites, objects, and districts may be designated as landmarks provided that the following conditions are met: 
Condition 1: the property fits within at least one of the following criteria:

(a) the property is associated with events that have made a significant contribution to the broad patterns of our history, including importance to a particular cultural or ethnic group;

(b) the property is associated with the lives of persons significant in our past;

(c) the property embodies the distinctive characteristics of a type, period, or method of construction, represents the work of a master, possesses high artistic value, or represents a significant and distinguishable entity whose components may lack individual distinctions

(d) the property has yielded, or may be likely to yield, information important in Texas culture or history;

Condition 2: the property retains integrity at the time of the nomination, as determined by the executive director of the commission; and

Condition 3: for buildings and structures only, the property must be listed in the NRHP, either individually, or as a contributing property within a historic district as determined by the Keeper of the National Register or the executive director of the commission (13 TAC 26.19).

\subsection{Curation}

The survey employed a non-collection strategy. Records, files, field notes, forms, and other documentation are included in the curation package. All field-generated documents are temporarily curated at the IES office and permanently curated at UTSA CAR. These documents and photographs were organized and catalogued according to CARL curation standards. 


\section{CHAPTER 5: RESULTS}

During this archeological survey, the APE was subjected to pedestrian reconnaissance survey transects and a systematic intensive survey. Pedestrian reconnaissance transects were conducted across the entire APE to confirm the extent of prior ground disturbances and assess the likelihood of encountering archeological resources. Ground surface visibility ranged from 0 to 100 percent across the APE, based on localized ground conditions. Intensive survey with systematic shovel test sampling in staggered intervals was conducted to confirm the extent and magnitude of previous disturbances and within undisturbed portions of the APE with the potential to contain archeological resources. During this survey, a historic-age archeological site (41WM1419) was documented within the direct APE. In addition, four architectural resources (AR) were identified within the indirect APE.

\section{$\underline{5.1}$ Archeological Survey}

\subsubsection{Pedestrian Survey}

During the background review, it was determined that ground-disturbing activities related to past land use have transpired within the APE. Currently, the APE is within a rural setting that has been heavily impacted by development associated with the community of Noack, road construction, and construction of multiple water pump facilities and associated pipelines. Historical aerial photographs indicate that properties within and adjacent to the APE were primarily used for agricultural purposes from as early as 1953.

During the survey, field investigations verified that past land use and construction of public facilities and utilities has caused surface and subsurface disturbances within a large percentage of the APE. The APE was located on properties generally featuring open grassland or scrubland settings. The topography within the APE ranged from gently sloping to artificially flat terrain within existing water facilities.

\subsubsection{Inline PS}

The Inline PS project area was situated southwest of the intersection of FM 112 and CR 432 in the small rural community of Noack. The APE featured an upland setting in the eastern half of the property that sloped westward towards an unnamed tributary of Brushy Creek (Appendix A, Photographs 1 through 7). IES investigators observed short and tall grass species mixed with forbs and secondary tree growth near structures and water resources. According to historical aerial photographs, three water retention ponds had been excavated in the western half of the APE. Currently, the northern two pond locations contain small wetlands (Appendix A, Photographs 8 and 9).

A barn, previously determined to be of modern age, was located in the eastern half of the Inline PS APE (Appendix A, Photographs 10 through 12). The barn had been converted into a bar venue but appeared to have been closed for some time and was in very poor condition at the time of survey. In the western half of the APE, archeologists encountered an excavated depression containing concrete debris and a pile of metal building materials (Appendix A, Photographs 13 through 18). Through field observations and additional background research, it was determined the scatter of concrete debris and pile of scrap metal were most likely related to the demolition of a nearby modern-age building and potentially a historic-age building that once stood in the eastern half of the APE. The debris scattering was considered to represent an archeological site (41WM1419), which is discussed in Section 5.2 of this chapter.

\subsubsection{Frame Switch PS}

The Frame Switch PS is located east of the existing PS facility on FM 3349. The topography within the property gently sloped northwards toward an unnamed tributary of Mustang Creek. The APE is entirely comprised of the existing PS, water tower, water tank, and associated infrastructure. Due to the extensive previous ground disturbances within this APE segment, related to previous water system improvement infrastructure, it was determined that there was negligible potential for archeological deposits (Appendix A, Photographs 19 through 20). 


\subsubsection{Shiloh PS}

The Shiloh PS is located west of FM 481 in the southeastern quadrant of Williamson County. The Shiloh PS project area featured a flat terrain and the existing facility, which included water pumps, a water tower, water tank, and associated infrastructure. In addition, recent construction activities have transpired within the western half of the APE as evidenced by 100 percent ground visibility related to recent grading and infrastructure improvements (Appendix A, Photographs 21 through 25). This disturbance combined with the low to negligible potential negated the need for shovel testing at this location.

\subsubsection{Intensive Survey}

During the IES survey, 21 shovel tests were excavated within the Inline PS APE (Figure 5.1). As discussed previously in this report, no shovel tests were excavated at the Frame Switch PS and Shiloh PS due to extensive previous ground disturbance and negligible to low archeological potential. Shovel testing within the eastern half of the Inline PS APE revealed a soil profile containing an upper stratum of very dark gray (10YR 3/1) clay loam or clay to a depth of approximately 10 to $30 \mathrm{~cm}$ below surface (cmbs; Table 5.1). Below this stratum was a compact fill layer of strong brown (7.5YR 5/6) loam and gravel. These shovel tests rarely exceeded $30 \mathrm{cmbs}$ in depth due to subsurface disturbances (Appendix A, Photographs 26 through 28). Shovel tests excavated in the western part of the property near the unnamed tributary or wetlands revealed a more uniform soil profile of very dark gray (10YR 3/1) or very dark brown (10YR 2/2) clay in the upper 30 to $65 \mathrm{~cm}$ (Appendix A, Photograph 29). Sterile subsoils of dark grayish brown (10YR $4 / 2$ ) clay loam or dark gray (2.5Y 4/1) clay underlay the upper stratum. Overall, shovel tests ranged between 5 to $70 \mathrm{cmbs}$ in depth. In addition to shovel testing, subsurface exposures including disturbed patches, backfill from auger tests performed during a recent geologic survey, and cut banks were examined.

Table 5-1: Shovel Test Results

\begin{tabular}{|c|c|c|c|c|}
\hline $\begin{array}{c}\text { Shovel } \\
\text { Test } \\
\end{array}$ & Stratum 1 & Stratum 2 & Stratum 3 & Termination \\
\hline AG01 & 0 - 10 cmbs: 10 YR 3/1 sandy clay loam & Not excavated & Not excavated & Disturbed at $10 \mathrm{cmbs}$ \\
\hline AG02 & 0 - 5 cmbs: 10YR 3/1 loam & Not excavated & Not excavated & Disturbed at 5 cmbs \\
\hline AG03 & 0 - 10 cmbs: 10YR 3/1 loam & Not excavated & Not excavated & Disturbed at $10 \mathrm{cmbs}$ \\
\hline AG04 & 0 - 30 cmbs: 10YR 3/1 clay loam & Not excavated & Not excavated & Disturbed at $30 \mathrm{cmbs}$ \\
\hline AG05 & 0 - 65 cmbs: 10YR 3/1 clay & 65 - 70 cmbs: $2.5 Y$ 4/1 clay & Not excavated & Sterile subsoil at $70 \mathrm{cmbs}$ \\
\hline AG06 & 0 - 10 cmbs: 10YR 3/1 loam & Not excavated & Not excavated & Disturbed at $10 \mathrm{cmbs}$ \\
\hline AG07 & 0 - 10 cmbs: $2.5 Y$ 5/6 clay loam & Not excavated & Not excavated & Disturbed at $10 \mathrm{cmbs}$ \\
\hline AG08 & 0 - 10 cmbs: 10YR 3/1 loam & Not excavated & Not excavated & Disturbed at $10 \mathrm{cmbs}$ \\
\hline AG09 & 0 - 5 cmbs: 10YR 3/1 loam & 5 - 10 cmbs: 7.5YR 5/6 loam & Not excavated & Disturbed at $10 \mathrm{cmbs}$ \\
\hline AG10 & 0 - 10 cmbs: 10YR 3/2 loam & Not excavated & Not excavated & Disturbed at $10 \mathrm{cmbs}$ \\
\hline AG11 & 0 - 40 cmbs: 10 YR 3/1 clay & Not excavated & Not excavated & Disturbed at $40 \mathrm{cmbs}$ \\
\hline AG12 & 0 - 50 cmbs: 10YR 3/1 clay & Not excavated & Not excavated & Compact soil at $50 \mathrm{cmbs}$ \\
\hline AG13 & 0 - 35 cmbs: 10YR 3/1 clay loam & 35 - 40 cmbs: 10YR 5/2 clay & Not excavated & Sterile subsoil at $40 \mathrm{cmbs}$ \\
\hline AG14 & 0 - 30 cmbs: 10 YR 3/1 clay loam & Not excavated & Not excavated & Disturbed at $30 \mathrm{cmbs}$ \\
\hline AG15 & 0 - 25 cmbs: 10YR 3/1 clay loam & 25 - 30 cmbs: 10YR 5/2 sandy clay loam & $\begin{array}{l}30 \text { - } 35 \text { cmbs: 10YR 2/1 clay } \\
\text { loam }\end{array}$ & Disturbed at $35 \mathrm{cmbs}$ \\
\hline AG16 & 0 - 30 cmbs: 10YR 3/1 clay loam & Not excavated & Not excavated & Disturbed at $30 \mathrm{cmbs}$ \\
\hline AG17 & 0 - 25 cmbs: 10YR 3/1 clay loam & 25 - 35 cmbs: 10YR 4/1 clay & Not excavated & Sterile subsoil at $35 \mathrm{cmbs}$ \\
\hline AG18 & 0 - 15 cmbs: 10 YR 3/2 clay loam & 15 - 30 cmbs: 10YR 4/1 clay & Not excavated & Sterile subsoil at $30 \mathrm{cmbs}$ \\
\hline WC01 & 0 - 50 cmbs: 10 YR 2/2 clay & 50 - 60 cmbs: 10YR 4/2 clay loam & Not excavated & Sterile subsoil at $60 \mathrm{cmbs}$ \\
\hline WC02 & 0 - 30 cmbs: 10 YR 2/3 clay & 30 - 50 cmbs: 10YR 2/2 clay & Not excavated & Disturbed at $50 \mathrm{cmbs}$ \\
\hline WC03 & 0 - 20 cmbs: 10YR 2/2 loam & 20 - 50 cmbs: 10YR 2/2 clay loam & Not excavated & Sterile subsoil at $30 \mathrm{cmbs}$ \\
\hline
\end{tabular}




\section{Restricted Information}

Map Removed

Contained Archeological Site Location Information 


\subsection{Encountered Cultural Resources}

\subsubsection{WM1419}

During the IES survey, newly recorded historic-age site 41WM1419 was encountered on a terrace within the Inline PS portion of the APE (Appendix A, Photograph 30). The site is located southwest of the intersection of FM 112 and CR 432 (Figure 5.2). The site was documented within an area extending approximately $112 \mathrm{ft}(34 \mathrm{~m})$ north-to-south by $278 \mathrm{ft}(85 \mathrm{~m})$ east-to-west, encompassing approximately 0.49 ac (0.2 ha). The site was delineated based on the distribution of archeological features, positive and negative shovel tests, and observed disturbances. Based on field observations and delineation shovel tests, it was determined that the site does not extend outside of the APE.

Ground surface visibility was limited to 30 percent or less throughout the delineation due to vegetation growth. No surface artifacts were observed during the survey; however, three surface features were present. During the delineation of site 41WM1419, IES investigators excavated 15 shovel tests, of which only three tested positive for cultural material. The soil profile exposed during shovel testing within the site consisted of an upper stratum of very dark gray (10YR 3/1) clay loam or clay (Appendix A, Photographs 31 and 32). Below the upper stratum, soils ranged from a strong brown to grayish brown (10YR 5/2) sandy clay loam to a dark gray or black (10YR 4/1 or 2/1) clay subsoil horizon. Shovel tests were generally terminated between 30 and $50 \mathrm{cmbs}$ due to culturally sterile subsoil or disturbed soils. Shovel tests excavated on the terrace revealed compact layers of soil and gravel fill. The three positive shovel tests (AG06, AG13, AG15) included a round nail and 11 brick fragments (Appendix A, Photographs 33 and 34). Delineation of these positive shovel tests were negative for additional archeological materials. Based on background review and field observations, it is likely the brick fragments were associated with past grading and filling on the upland terrace and slope.

\subsubsection{Features}

Feature 1 was a concrete foundation measuring approximately 100 by $36 \mathrm{ft}$ (30 by $11 \mathrm{~m}$; Appendix A, Photographs 35 through 38). This feature was located approximately $60 \mathrm{ft}(18 \mathrm{~m})$ south of FM 112 within the APE. The foundation consisted of a concrete slab with anchor bolts extruding from the surface, cinder blocks, and a set of stairs. Historical maps and aerial photographs indicate the feature was part of a building that was constructed prior to 1934 and demolished in 2005 or 2006.

Feature 2 was a concrete-lined water well adjacent to the northeast corner of Feature 1 (Appendix A, Photographs 39 and 40). The well had a diameter of approximately $37 \mathrm{in}$. The above-ground collar typical of most water wells had been removed from the feature. The well is not visible on historical aerial photographs.

Feature 3 was a squarish, concrete cistern or well measuring approximately 3 by $3 \mathrm{ft}$ (1 by $1 \mathrm{~m}$ ) near a modern barn (Appendix A, Photographs 41 and 42). The feature was located approximately $120 \mathrm{ft}$ (36 $\mathrm{m})$ southwest of Feature 1 . The feature appears to have been partially destroyed as evident by large concrete fragments covering the opening. A metal pipe was observed within the feature.

\subsubsection{Archival Research}

The site is located within the 4,428-ac Hamilton White Survey, Abstract 647, patented on 24 February 1845. Using public records provided by the WCCO a chain-of-title for the property was produced to determine potential eligibility under Criterion A and/or B of the NRHP (Table 5.2). Based on deed records and site observations, the property ownership of site 41WM1419 most likely pertains to the Zieschang and Lange families during the $20^{\text {th }}$ century. None of the names presented within the chain-of-title were listed in the Handbook of Texas Online, the TxGenWeb Project website, or other sources for local history. 


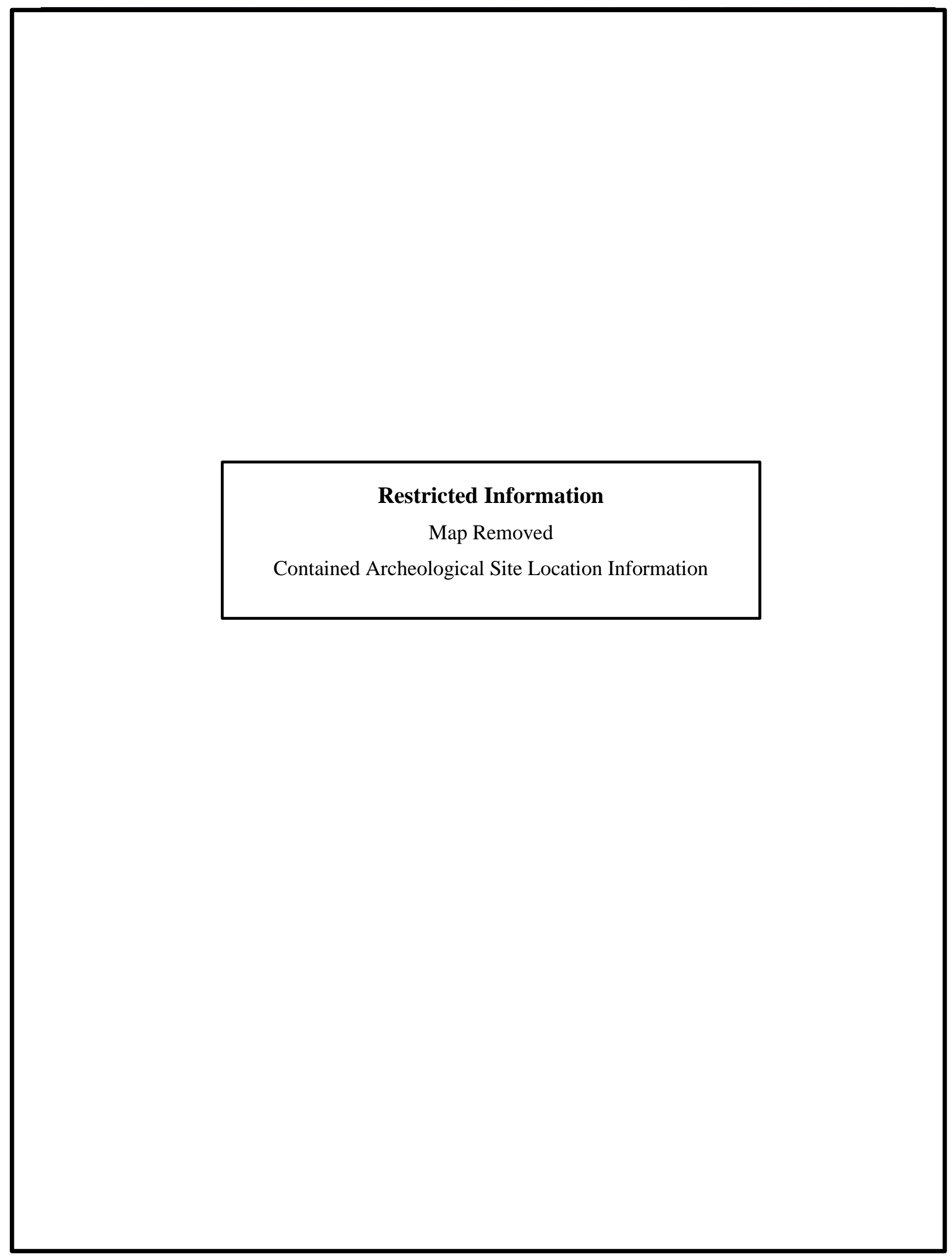

COH Transmission and Distribution Pumping Stations Phase I Project Cultural Resources Survey Report

IES Project No. 04.274.008

Page 29 
Table 5-2: Chain of Title for 41WM1419

\begin{tabular}{|c|c|c|c|c|}
\hline Grantor & Grantee & Date & Volume & Page \\
\hline O.W. Zieschang and Alma Zieschang & J.A. Zieschang & $04 / 01 / 1921$ & 200 & 403 \\
\hline J.A. Zieschang, deceased & Heirs of J.A. Zieschang & $\begin{array}{l}\text { DOD } \\
03 / 13 / 1964 \\
\end{array}$ & - & - \\
\hline $\begin{array}{l}\text { Louis A. Zieschang, individually and as } \\
\text { Independent Executor of the Estate of J.A. } \\
\text { Zieschang, deceased; Selma Zieschang, Walter R. } \\
\text { Zieschang, Herbert Zieschang, Edna Hejl, Nelben } \\
\text { Hejl, Rosalie Krueger, A.W. Krueger, Esther Ruth } \\
\text { Lange, R.W. Lange, Amost A. Zieschang, Albert J. } \\
\text { Zieschang, Jr., and Karen Zieschang }\end{array}$ & $\begin{array}{l}\text { Walter R. Zieschang and Clarence R. } \\
\text { Zieschang }\end{array}$ & 08/11/1964 & 471 & 239 \\
\hline $\begin{array}{l}\text { Walter R. Zieschang, individually and as } \\
\text { Independent Executor of the Estate of J.A. } \\
\text { Zieschang, deceased; Edna Zieschang, Louis A. } \\
\text { Zieschang, Selma Zieschang, Herbert Zieschang, } \\
\text { Rosalie Krueger, A.W. Krueger, Clarence R. } \\
\text { Zieschang, Minnie Zieschang, Albert J. Zieschang, } \\
\text { Jr., and Karen Zieschang }\end{array}$ & $\begin{array}{l}\text { Amos A. Zieschang, Edna Hejl, and } \\
\text { Esther Ruth Lange }\end{array}$ & 08/11/1964 & 471 & 251 \\
\hline $\begin{array}{l}\text { Amos A. Zieschang, Edna Hejl, Nelben Hejl, Esther } \\
\text { Ruth Lange, and R.W. Lange }\end{array}$ & Allen Ahrens, Sr. and Grayce Ahrens & 09/21/1964 & 472 & 25 \\
\hline $\begin{array}{l}\text { Walter R. Zieschang, Edna Zieschang, Clarence R. } \\
\text { Zieschang, and Minnie Zieschang }\end{array}$ & Herbert Zieschang & 08/17/1965 & 480 & 512 \\
\hline Allen Ahrens, Sr. and Grayce Ahrens & Herbert Zieschang & $06 / 03 / 1969$ & 518 & 116 \\
\hline Herbert Zieschang, deceased & Heirs of Herbert Zieschang & $07 / 24 / 1973$ & - & - \\
\hline $\begin{array}{l}\text { Clarence R. Zieschang, individually and as } \\
\text { Independent Executor of the Estate of Herbert } \\
\text { Zieschange, deceased; Minnie Zieschang, } \\
\text { Wuandene Finn, Lee Roy Finn, Louis A. } \\
\text { Zieschang, Selma Zieschang, Edna Zieschang Hejl, } \\
\text { Nelben Hejl, Rosalie Zieschang Krueger, Amos A. } \\
\text { Zieschang, Albert J. Zieschang, Jr., Joyce Karon } \\
\text { Zieschang, Rankin Scott Zieschang, Lucy Lavern } \\
\text { Zieschang, Yvonne Tucek, Jerome Tucek, Esther } \\
\text { Ruth Zieschang, and R.W. Lange }\end{array}$ & Dennis Lange and Jane Anne Lange & $04 / 12 / 1974$ & 586 & 617 \\
\hline Dennis Lange and Jane Anne Lange & George H. Hendrix and Mary A. Hendrix & $04 / 19 / 1981$ & 841 & 910 \\
\hline George H. Hendrix and Mary A. Hendrix & Nancy Pfluger & $03 / 07 / 1988$ & 1640 & 192 \\
\hline Nancy Pfluger & Ronald Wayne Hejl and Diana Lynn Hejl & $09 / 16 / 1988$ & 1711 & 921 \\
\hline Ronald Wayne Hejl and Diana Lynn Hejl & D.R. Ferrari & $10 / 29 / 1990$ & 1971 & 633 \\
\hline D.R. Ferrari & Susanne Ferrari and Donald R. Ferrari & $06 / 14 / 1999$ & 1999041474 & - \\
\hline Susanne Ferrari and Donald R. Ferrari & Elton Malish and Frankie Limmer & $12 / 15 / 2005$ & 2005100697 & - \\
\hline Elton Malish and Frankie Limmer & Heart of Texas Suppliers LP & $05 / 25 / 2006$ & 2006066337 & - \\
\hline Heart of Texas Suppliers LP & City of Hutto & $10 / 12 / 2017$ & 2017098333 & - \\
\hline
\end{tabular}

\subsubsection{Site Summary}

Site 41WM1419 occupied an area approximately $112 \mathrm{ft}$ (34m) north-to-south by $278 \mathrm{ft}$ (85 m) east-to-west, encompassing approximately 0.19 ac $(0.2 \mathrm{ha})$. Fifteen shovel tests were excavated within or in proximity to the site during intensive survey and site delineation, three of which yielded cultural materials. During the IES survey, a foundation feature, well, and cistern were identified within the site. Based on background research and field observations, site $41 \mathrm{WM} 1419$ was occupied during the $20^{\text {th }}$ century.

\subsection{Architectural Resources Assessment}

To satisfy Section 106 requirements for the Inline PS, indirect visual impacts must be assessed. The indirect APE was designed to include the maximum distance adverse visual impacts of a new PS facility could occur to historic-age buildings and structures in the vicinity of the Inline PS APE. The indirect APE incorporated a 200-ft-wide buffer surrounding the direct APE. Through the reconnaissance survey, a total of four ARs within the indirect APE were identified and documented (Figure 5.3). The ARs assessed included residential homes and commercial business buildings. All resources were constructed in the early or mid- $20^{\text {th }}$ century. Representative photographs of each resource are provided within Appendix B. 


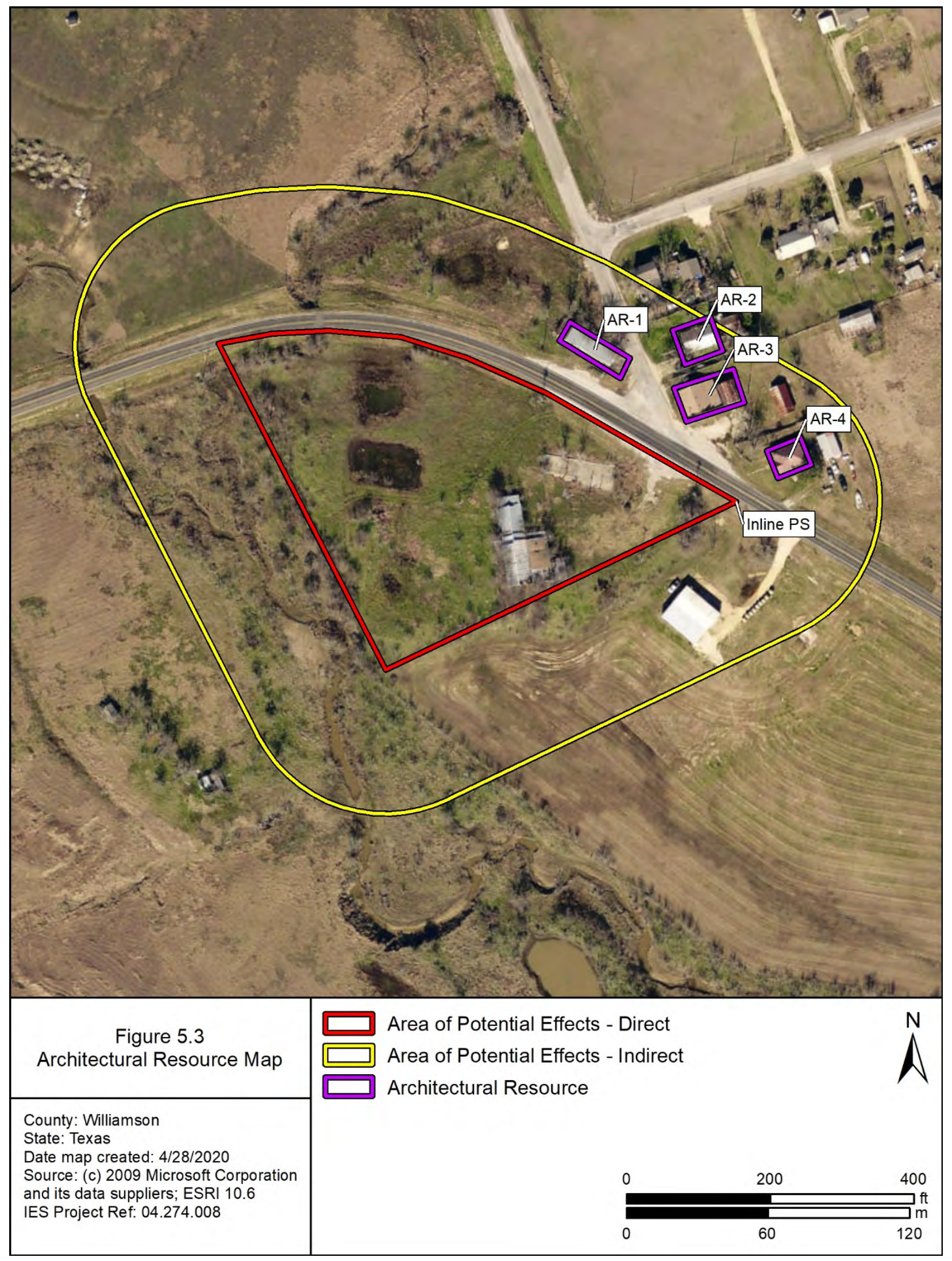


This page intentionally left blank

COH Transmission and Distribution Pumping Stations Phase I Project Cultural Resources Survey Report

IES Project No. 04.274.008

Page 32 


\section{CHAPTER 6: SUMMARY AND RECOMMENDATIONS}

During the intensive pedestrian survey, 21 shovel tests were excavated within the 6.63-ac APE. Through the survey, one newly recorded archeological site was documented within the APE. A summary of the archeological resource encountered, and NRHP/SAL eligibility recommendations are provided within this chapter. IES considers the entire APE to be fully assessed for archeological resources at this time and recommends that no further work is warranted. The eligibility recommendations of this cultural resources is briefly summarized within Table 6.1 and detailed within the following chapter. The four AR located within the indirect APE were photographed but were not evaluated for NRHP eligibility during this project as it was assumed that the project had no potential for adverse effect.

Table 6-1: Summary of NRHP Eligibility Recommendations

\begin{tabular}{|c|c|c|}
\hline Resource ID & APE Location & NRHP Eligibility Recommendations \\
\hline \hline 41WM1419 & Direct & Not Eligible \\
\hline
\end{tabular}

41WM1419 represents a newly recorded historic-period site used during the $20^{\text {th }}$ century. During the IES survey, archeologists identified three archeological features including a building foundation, well, and cistern. All historic-aged structures once present at the site have been demolished and the contextual integrity of the site has been severely compromised. The site does not retain sufficient data to contribute important information regarding community development in Williamson County or the greater region during the $20^{\text {th }}$ century. As such, site $41 \mathrm{WM} 1419$ is considered to have little research potential and is not likely to yield any additional information relevant to understanding the historic period within the region. Based on the lack of association with a significant historical event(s) or person(s), the absence of innovative or artistic design elements or architectural features, and the low potential to yield significant archeological data, site 41WM1419 is recommended to remain not eligible for listing in the NRHP under Criteria A, B, C, or D nor considered for SAL designation. No further evaluation or mitigation efforts are recommended for this site.

Therefore, it is the recommendation of IES that the $\mathrm{COH}$ Transmission and Distribution Pumping Stations Phase I project be permitted to continue without the need for further cultural resource investigations. However, if any cultural resources, other than those detailed within this report, are unearthed during construction, the operators should stop construction activities immediately in those areas. The project cultural resources consultant should then be contacted to initiate further consultation with the THC prior to resuming construction activities. In addition, if project designs change, and areas outside the APE detailed within this report are to be impacted, additional field investigations may be required. 
This page intentionally left blank

COH Transmission and Distribution Pumping Stations Phase I Project Cultural Resources Survey Report

IES Project No. 04.274 .008

Page 34 


\section{CHAPTER 7: REFERENCES CITED}

Collins, Michael B.

2004 Archeology in Central Texas. In The Prehistory of Texas. 1st ed. College Station: Texas A\&M University Press.

Council of Texas Archeologists (CTA)

2002 Revised Archeological Survey Standards for Texas. CTA Newsletter 26(1).

Diamond, David D. and Fred E. Smeins

1993 The native plant communities of the Blackland Prairie. In: Sharpless, M.R. and J.C. Yelderman (eds.). The Texas Blackland Prairie, land, history, and culture. Baylor University, Program for Regional Studies, Waco, Texas. pp. 66-81.

Eidson, J., and Fred E. Smeins

2020 "World Wildlife Fund." s.v. "Blackland Prairie,"

http:// https://www.worldwildlife.org/ecoregions/na0814/ (accessed March 2020).

Griffith, Glenn, Sandy Bryce, James Omernik, and Anne Rogers

2007 Ecoregions of Texas. Texas Commission on Environmental Quality.

Handbook of Texas Online

2019a "Brushy Creek (Williamson County),"

http://www.tshaonline.org/handbook/online/articles/rbbky/ (accessed September 2019).

2019b "Middle Yegua Creek (Williamson County),"

http://www.tshaonline.org/handbook/online/articles/rbm78 (accessed September 2019).

2019c “Mustang Creek (Williamson County),”

http://www.tshaonline.org/handbook/online/articles/rbmfn/ (accessed September 2019).

Hester, Thomas

1995 The Prehistory of South Texas. In The Bulletin of the Texas Archeological Society, Vol. 66.

Housh, Todd B.

2007 Bedrock Geology of Round Rock and Surrounding Areas, Williamson and Travis Counties, Texas. Geological Sciences, The University of Texas, Doctoral thesis.

Koszarek, Megan A., Diana Garnett, and Ann Keen

2017 Intensive Cultural Resources Survey for the Proposed CR 101 Road Construction Project, Williamson County, Texas. Texas Antiquities Permit No. 7694. HDR, Inc. Dallas, Texas.

"Little Noack claims old-world Zieschang Bar"

1982 Austin American-Statesman. Published 27 November 1982, Page 105.

https://www.newspapers.com/clip/30606235/noack-bar/ (accessed March 2020).

Odintz, Mark

2019 Handbook of Texas Online. s.v. "Williamson County,"

https://tshaonline.org/handbook/online/articles/hcw11 (accessed March 2020)

Owens, Jeffery D

2011 Intensive Archeological Survey for the Farm-to-Market Road 1660 Realignment Project, Hutto, Williamson County, Texas. TxDOT CSJ No. 1566-01-009 (Austin District). Texas Antiquities Permit No. 5788. Horizon Environmental Services, Inc. Austin, Texas. 
Proctor, C. V., J. H. McGowen, and W. T. Haenggi

1981 Geological Atlas of Texas, Austin Sheet. Bureau of Economic Geology, The University of Texas

Scarbrough, Clara Stearns

2016 Handbook of Texas Online. s.v. "Noack, Texas,"

https://tshaonline.org/handbook/online/articles/hnn26 (accessed March 2020)

Smyrl, Vivian Elizabeth

2010 Handbook of Texas Online. s.v. “Travis County”, https://shaonline.org/handbook/online/articles/hcm08 (accessed July 2017)

Texas Archeological Sites Atlas (TASA)

2020 “Texas Archeological Sites Atlas.” s.v. "Williamson County,” http://nueces.thc.state.tx.us/ (accessed March 2020).

Texas Historic Sites Atlas (THSA)

2020 “Texas Historic Sites Atlas.” s.v. "Williamson County,” http://nueces.thc.state.tx.us/ (accessed March 2020).

U.S. Department of Agriculture (USDA)

2020 Web Soil Survey, Natural Resource Conservation Service Website: http://websoilsurvey.nrcs.usda.gov/app/WebSoilSurvey (accessed March 2020).

U.S. Geological Survey (USGS)

2020 U.S. Department of the Interior Mineral Resources On-Line Spatial Data Website. http://mrdata.usgs.gov/sgmc/tx.html (accessed March 2020).

Werchan, Leroy E., and John L. Coker

1983 Soil Survey of Williamson County, Texas. United States Department of Agriculture, Soil Conservation Service, in cooperation with Texas Agricultural Experiment Station and Texas State Water Conservation Board. 


\begin{tabular}{c}
\hline Restricted Information \\
Map Removed \\
Contained Archeological Site Location Information \\
\hline
\end{tabular}




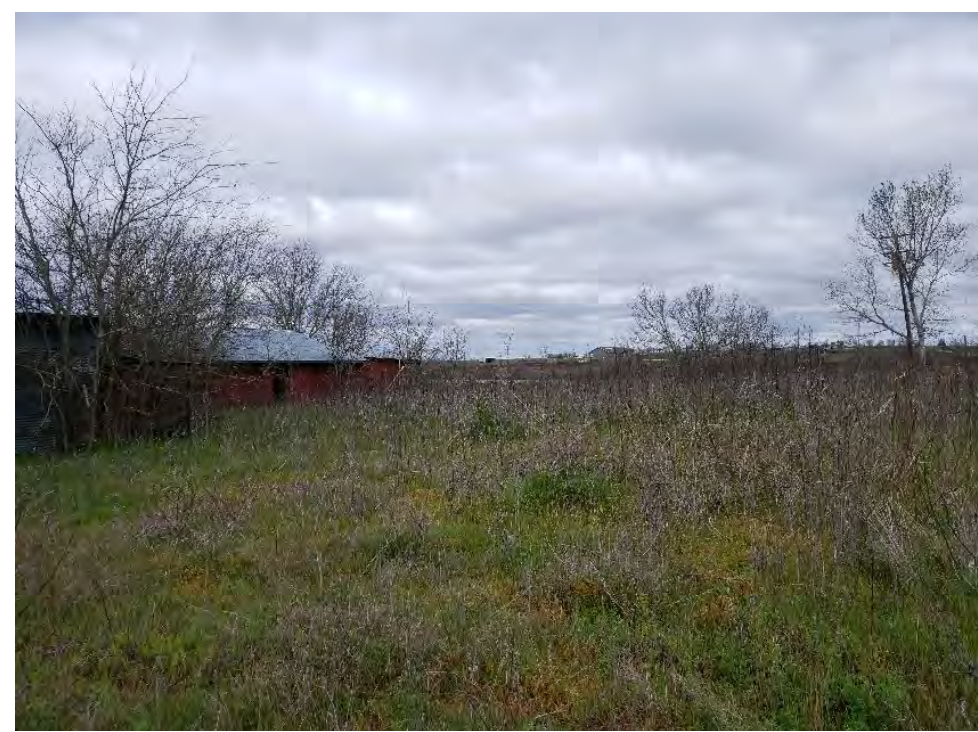

Photograph 1 - Inline PS APE, barn and grass field, view to the northwest.

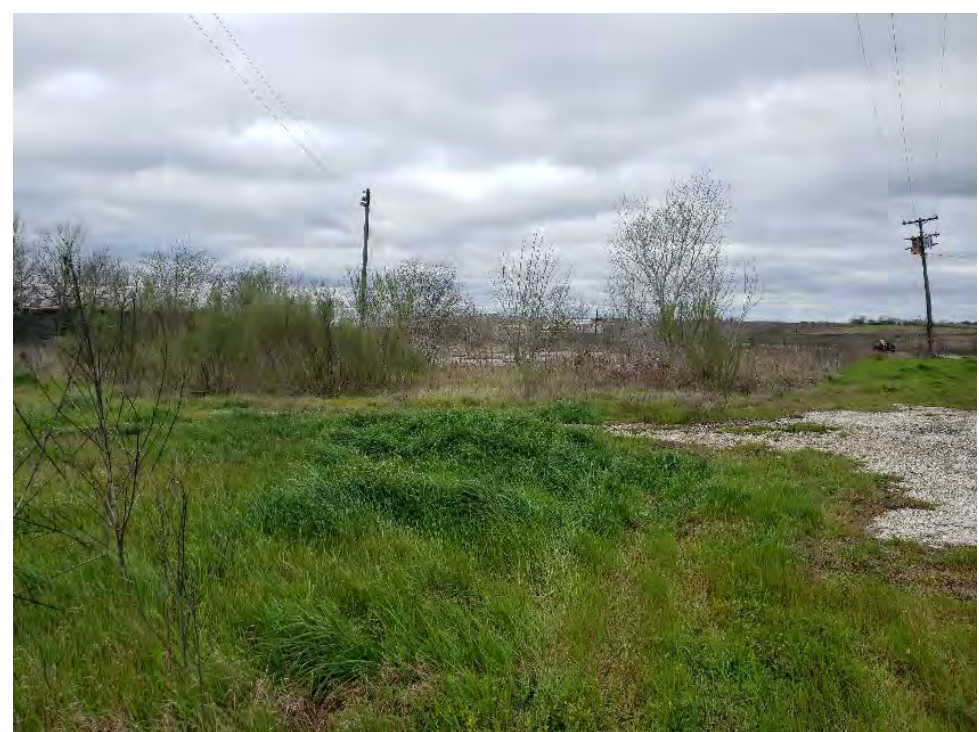

Photograph 3 - Inline PS APE, general setting, view to the northwest.

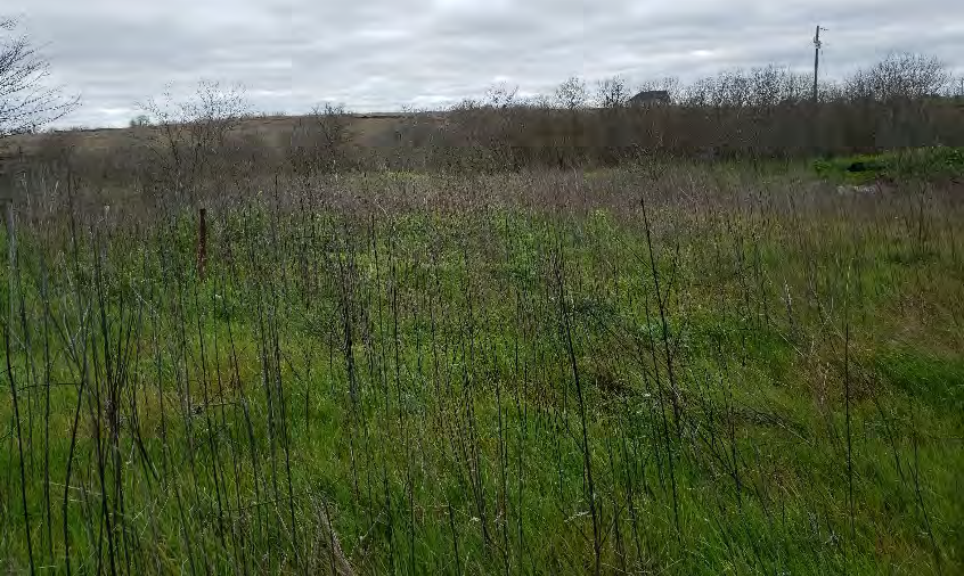

Photograph 5 - Inline PS APE, general setting, view to the west.

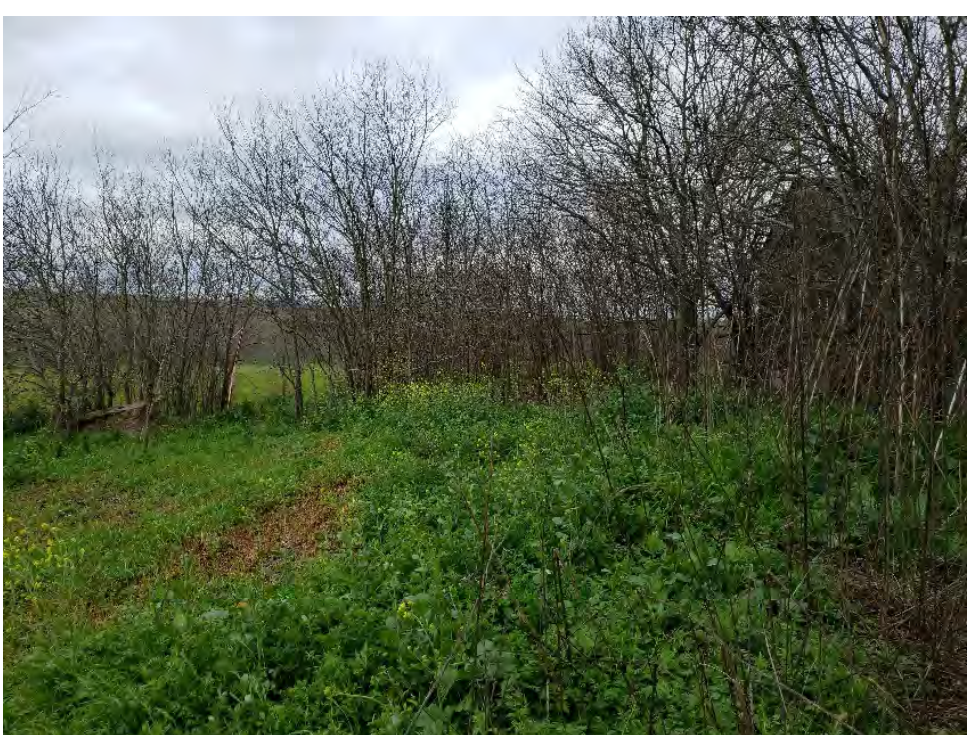

Photograph 2 - Inline PS APE, general setting, view to the south.

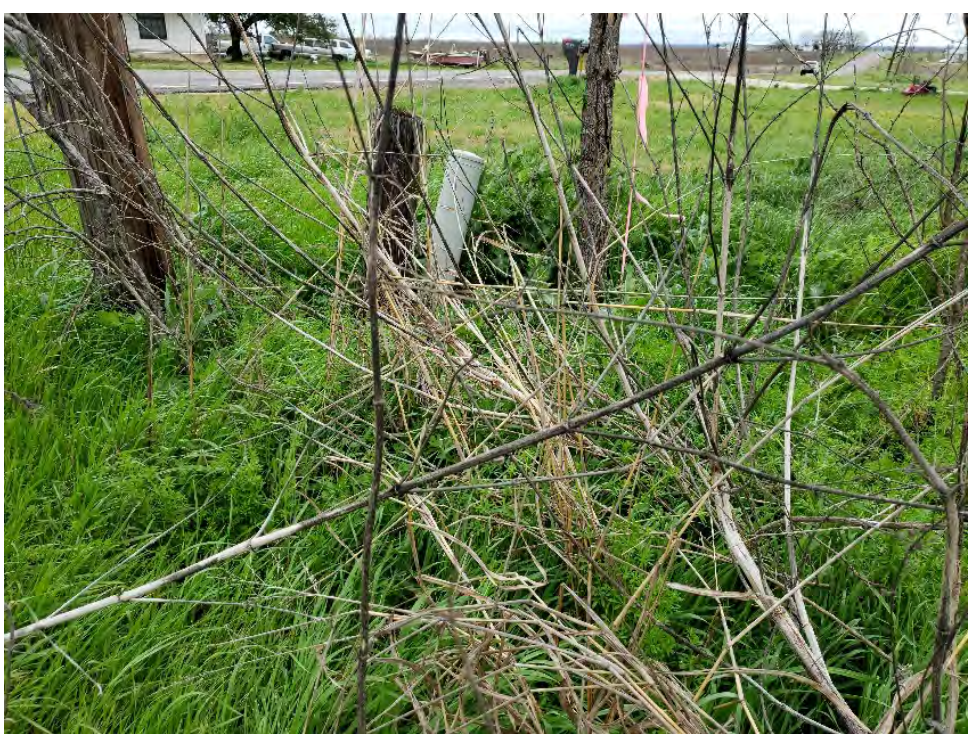

Photograph 4 - Vegetation near utility lines, view to the northeast.

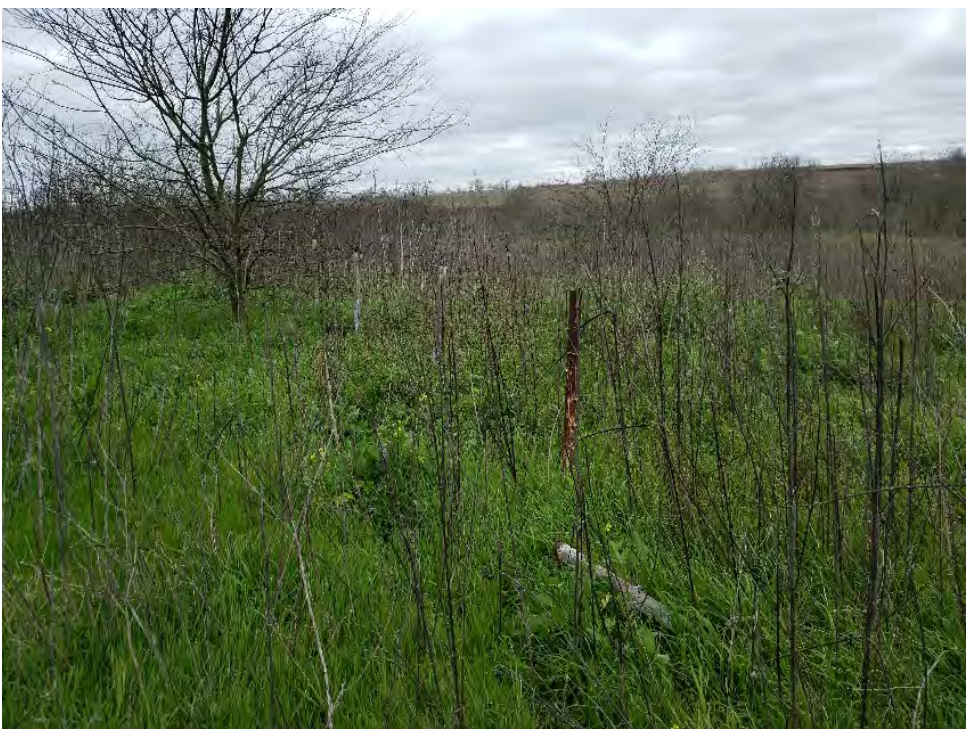

Photograph 6 - Inline PS APE, general setting, metal pipe fencing, view to the southwest. 


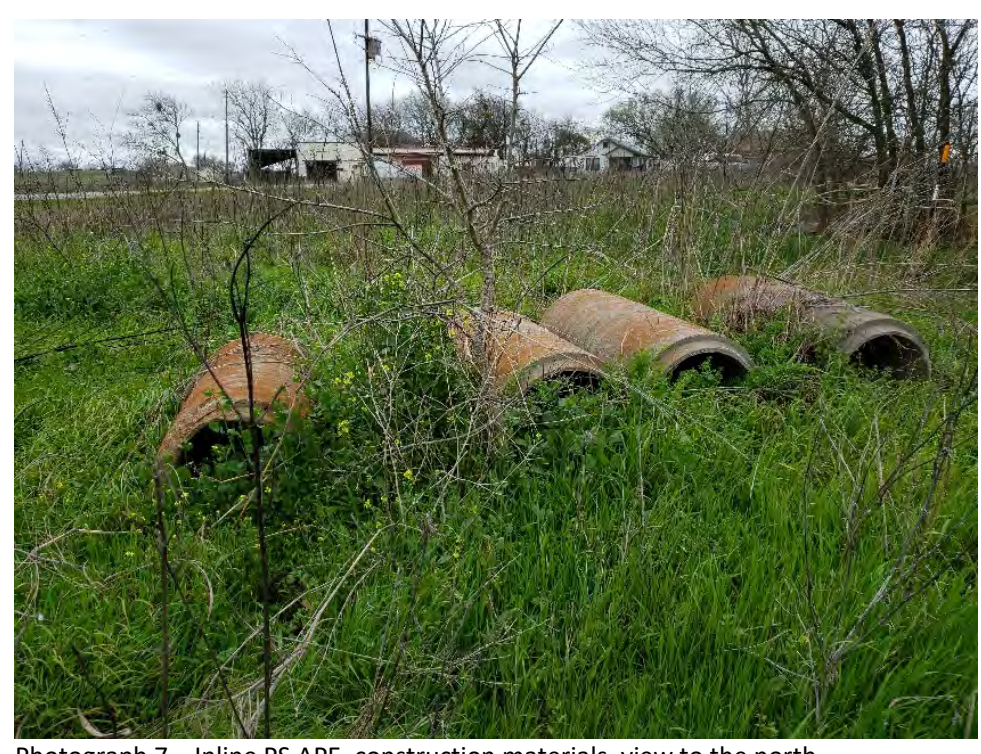

Photograph 7 - Inline PS APE, construction materials, view to the north.

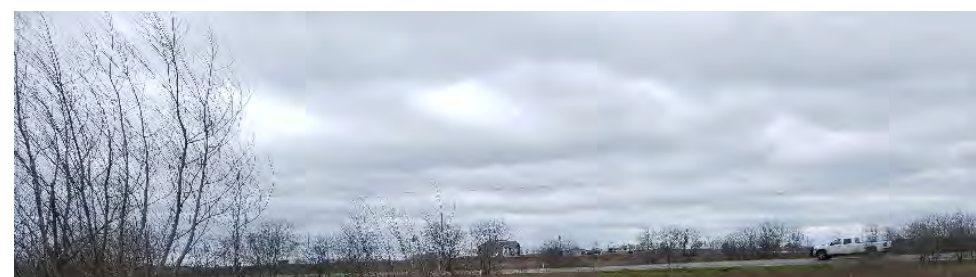

Photograph 9 - Inline PS APE, depression full of concrete debris, view to the north

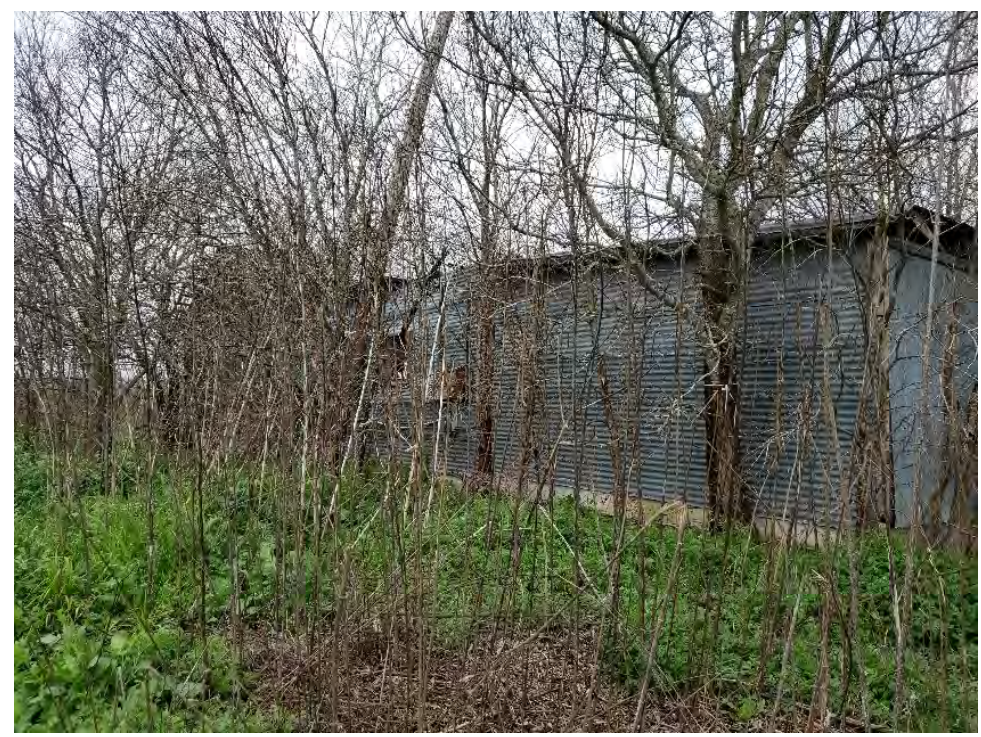

Photograph 11 - Inline PS APE, modern barn, view to the northwest.

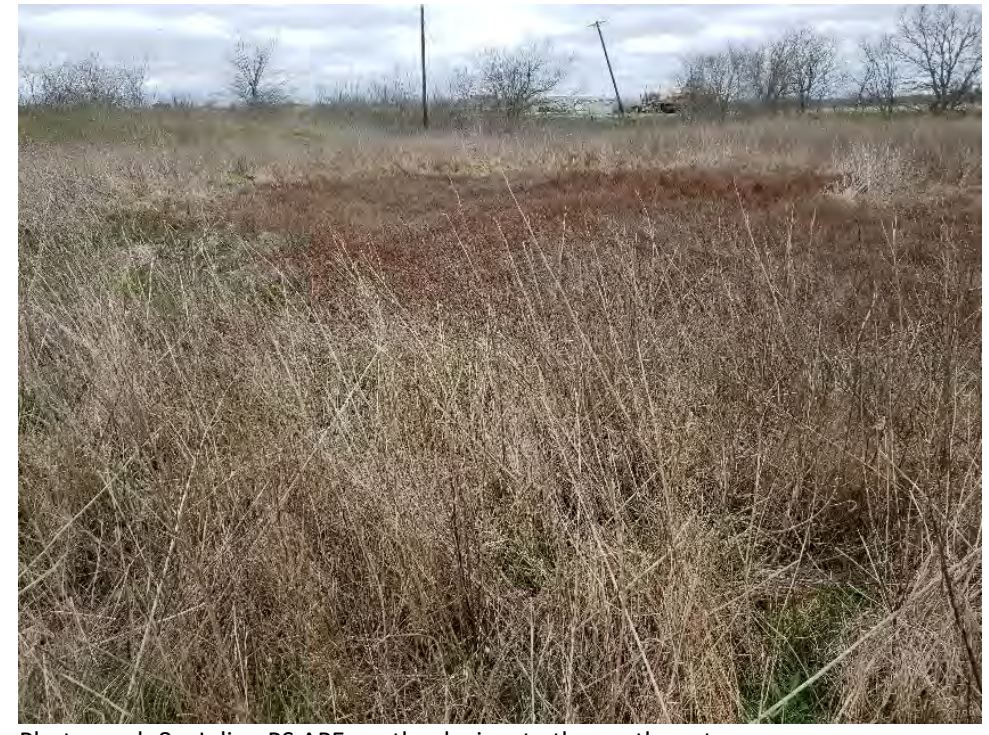

Photograph 8 - Inline PS APE, wetland, view to the northwest.

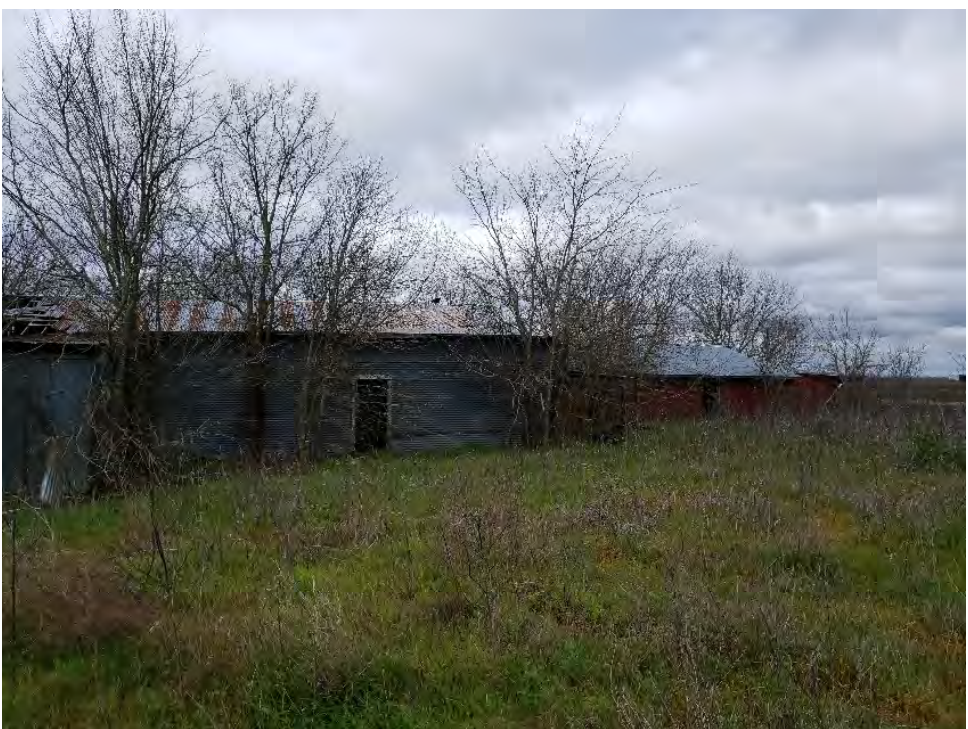

Photograph 10 - Inline PS APE, modern barn, view to the west.

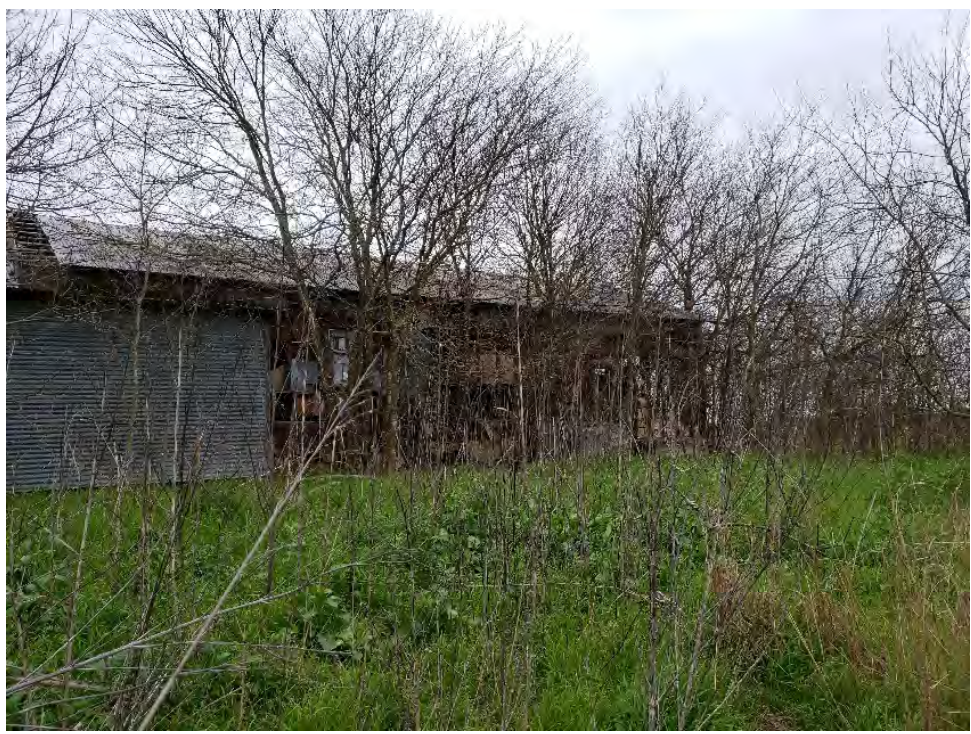

Photograph 12 - Inline PS APE, modern barn, view to the southeast. 


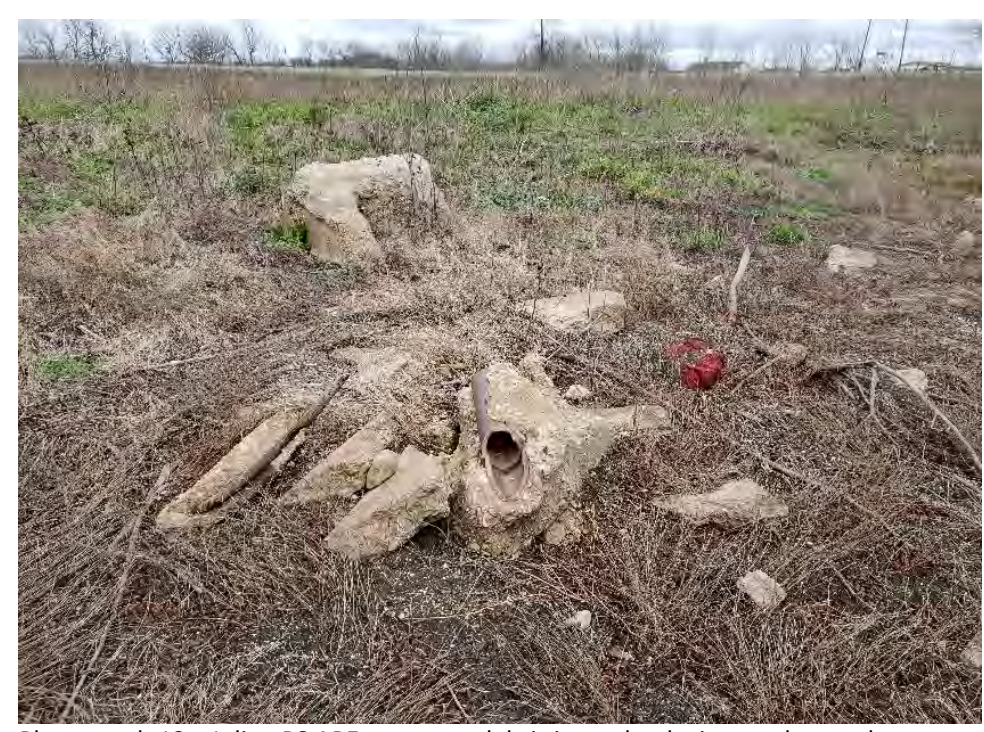

Photograph 13 - Inline PS APE, concrete debris in wetland, view to the northwest.

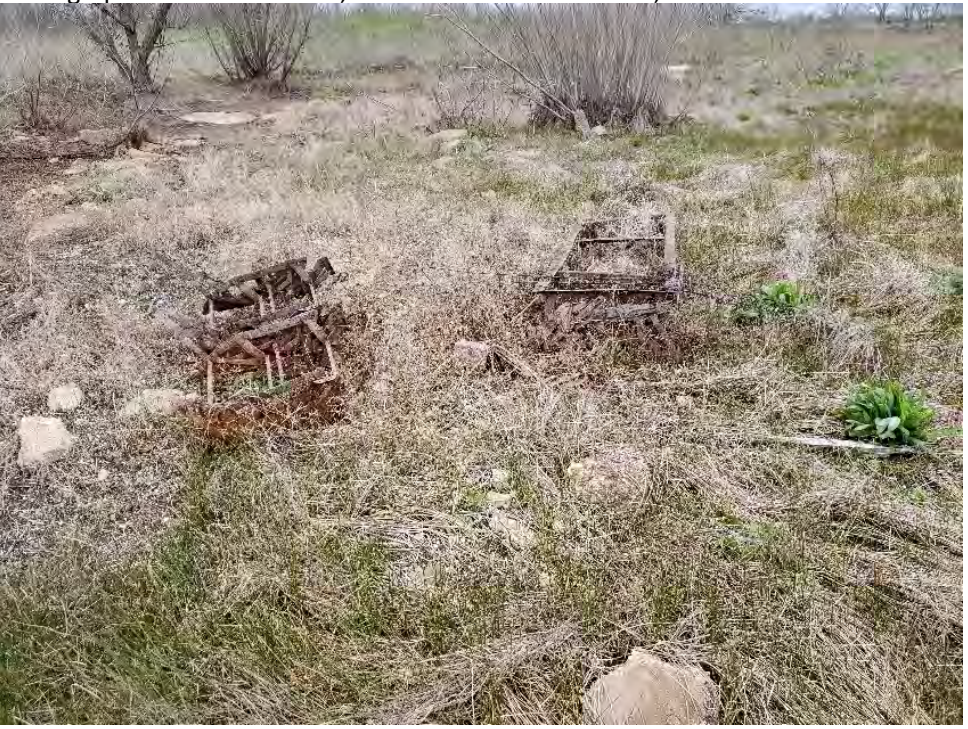

Photograph 15 - Inline PS APE, equipment and debris in wetland, view to the northwest.

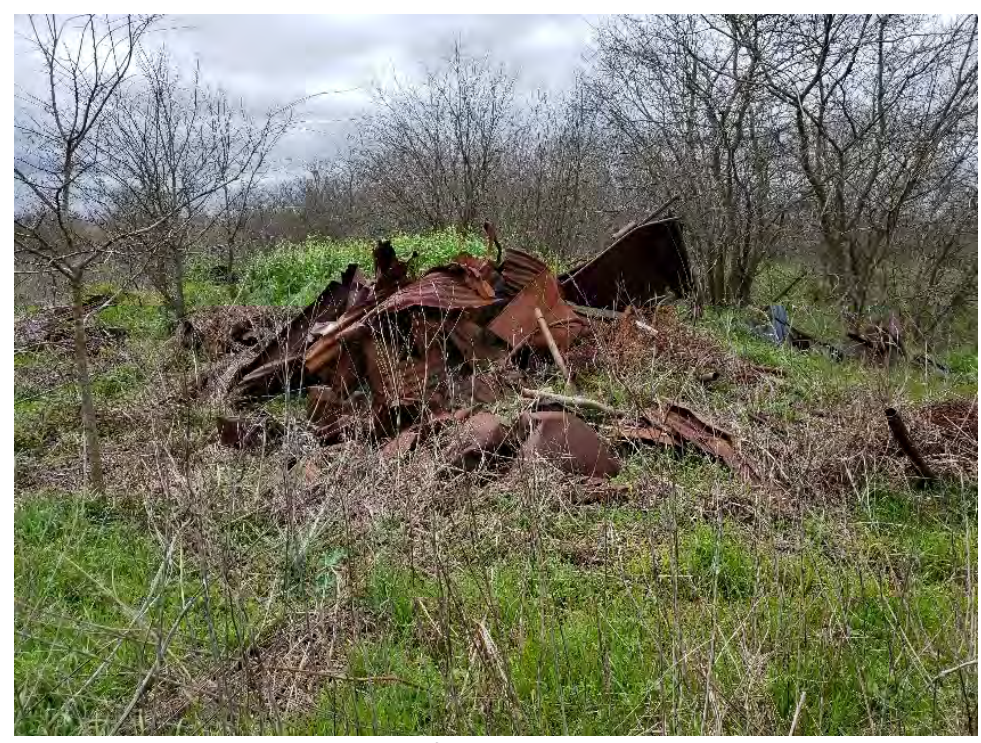

Photograph 17 - Inline PS APE, pile of sheet metal, view to the west.

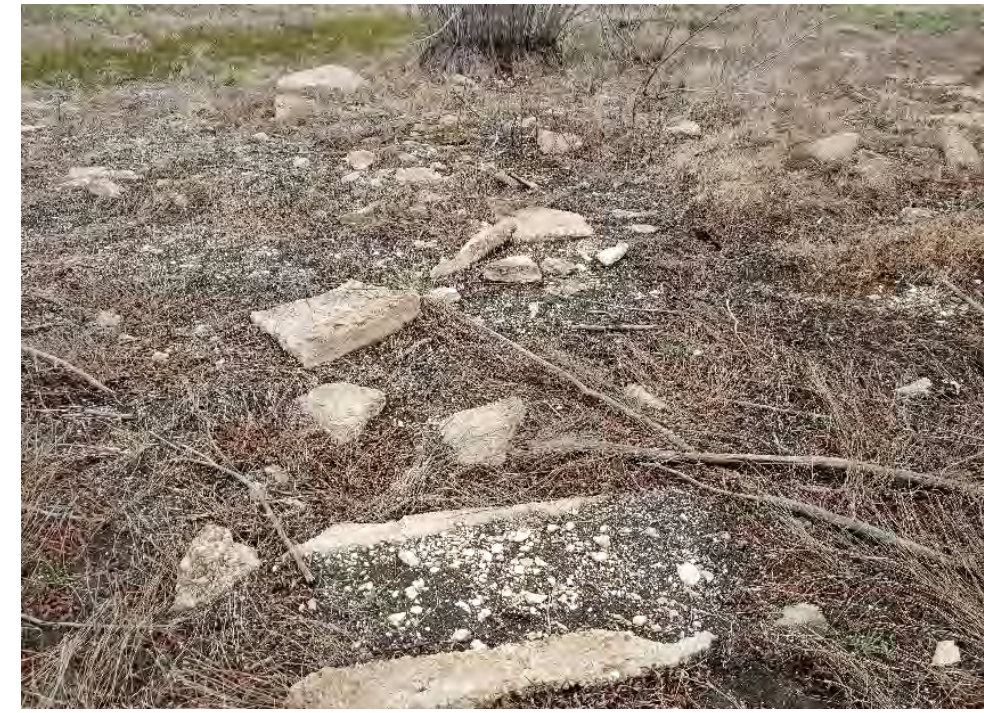

Photograph 14 - Inline PS APE, concrete debris in wetland, view to the north

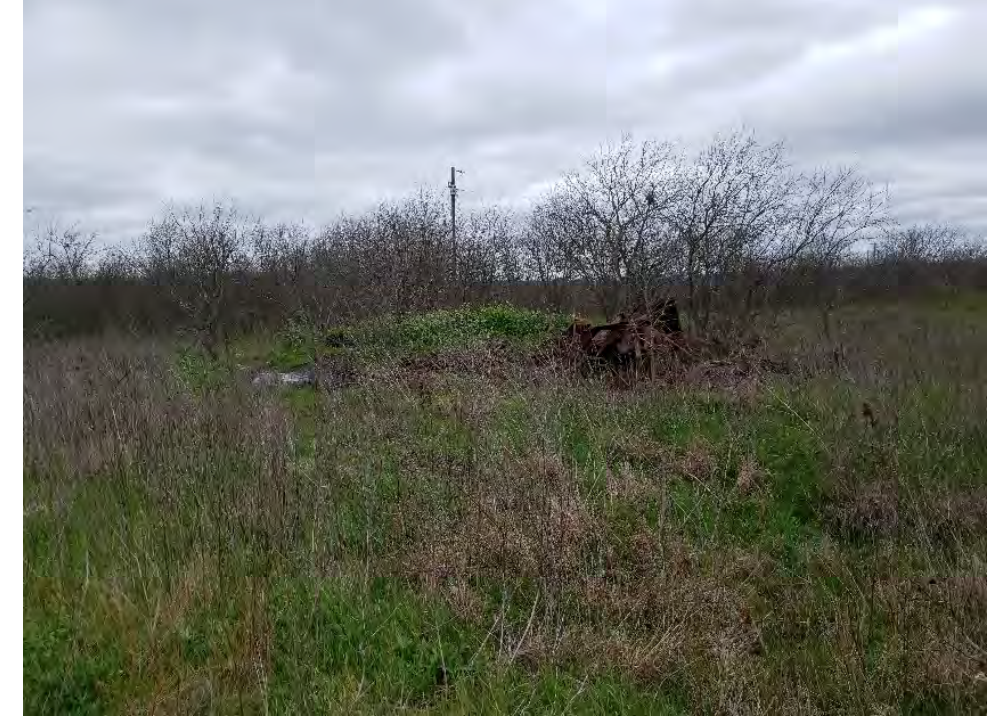

Photograph 16 - Inline PS APE, pile of rusted metal, view to the west.

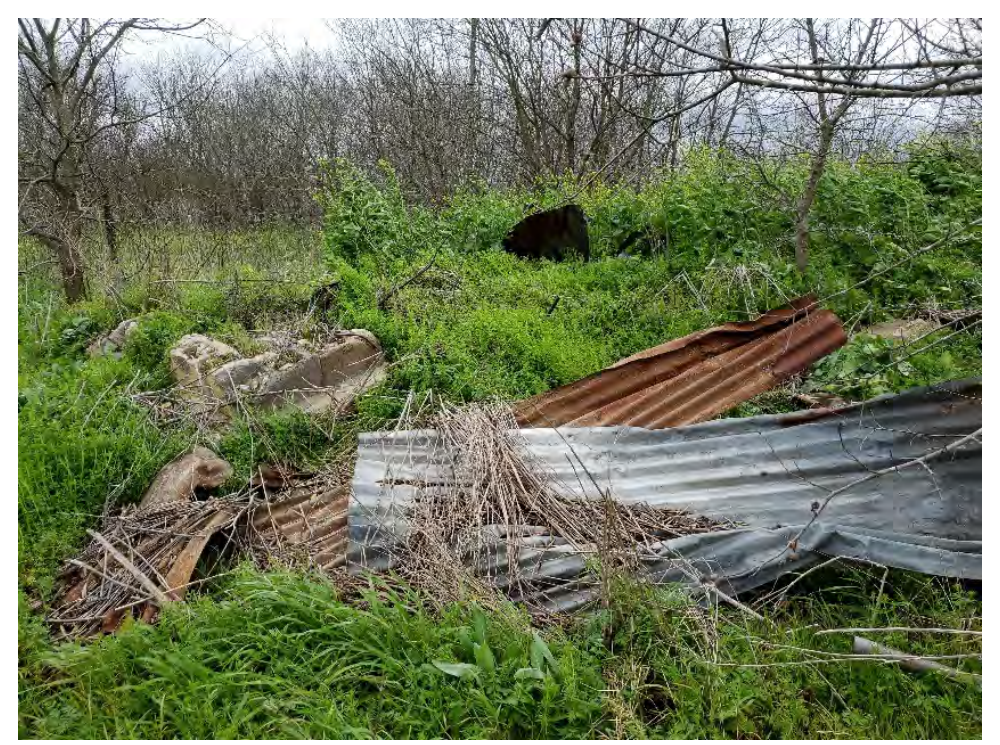

Photograph 18 - Inline PS APE, metal and concrete chunks, view to the west. 


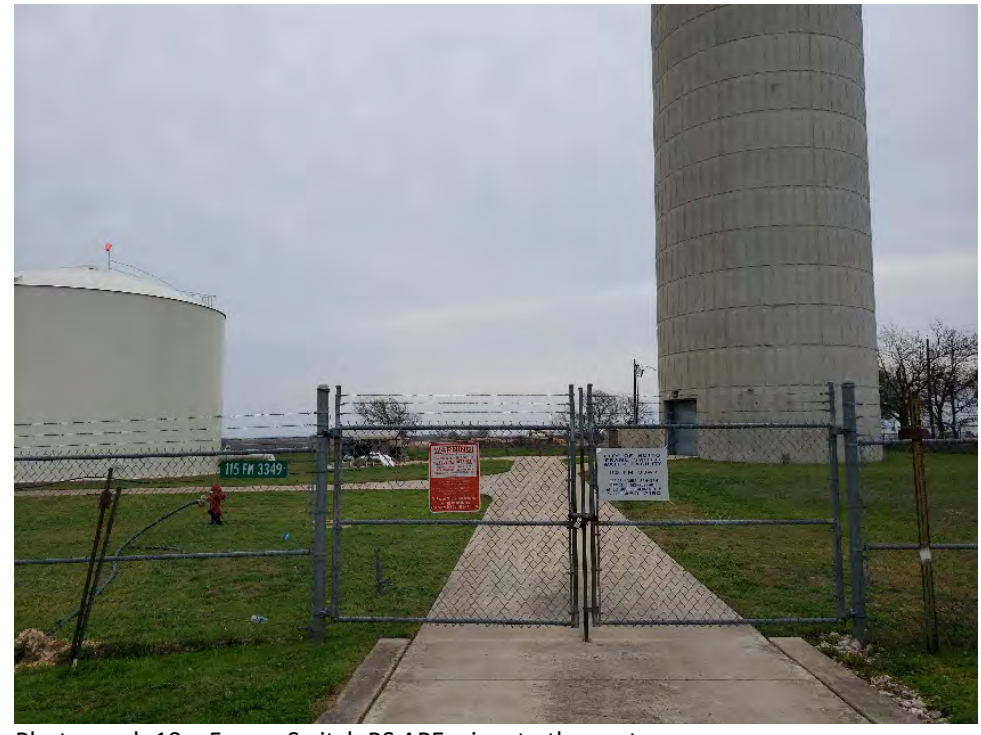

Photograph 19 - Frame Switch PS APE, view to the east.

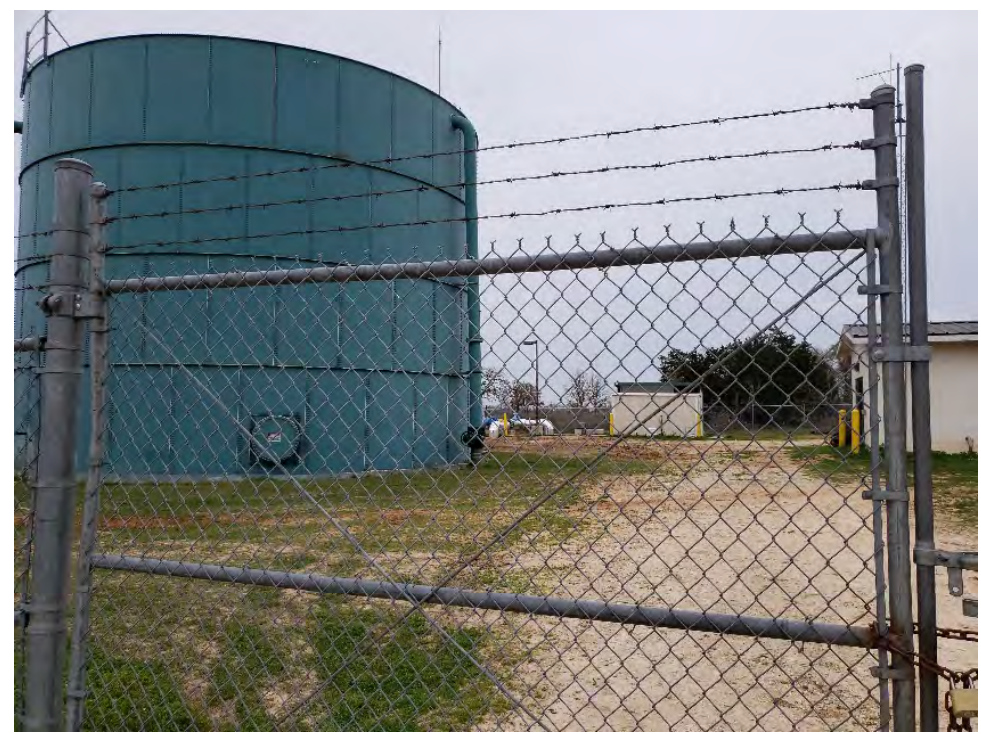

Photograph 21 - Shiloh PS APE, view to the north.

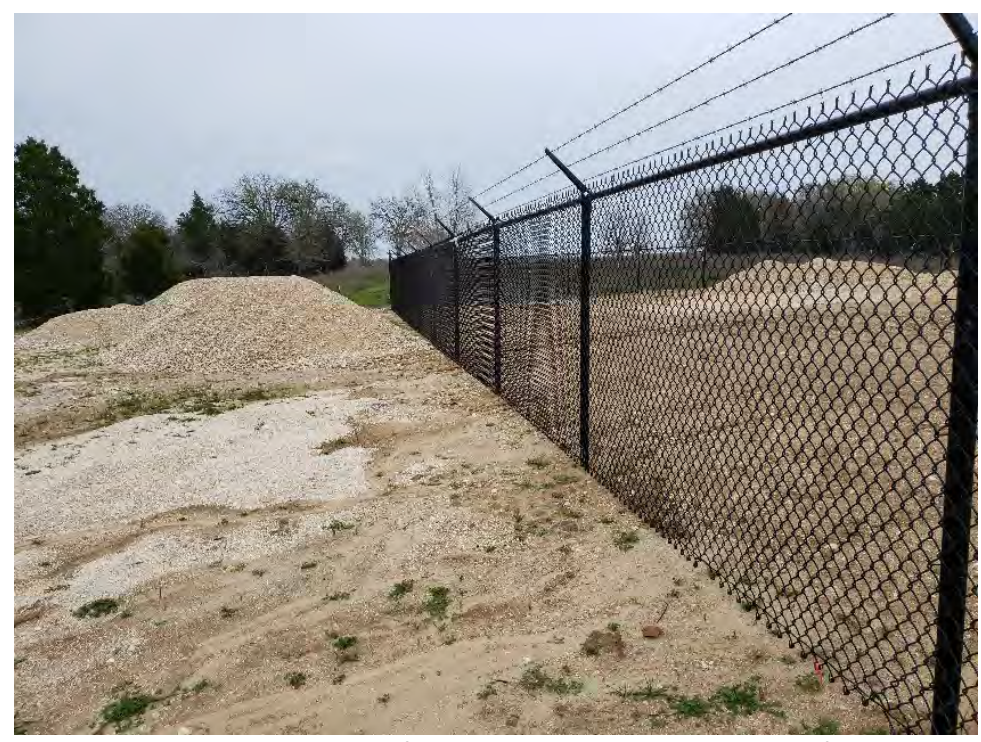

Photograph 23 - Shiloh PS, piles of gravel and dirt within and outside of APE, view to the northeast.

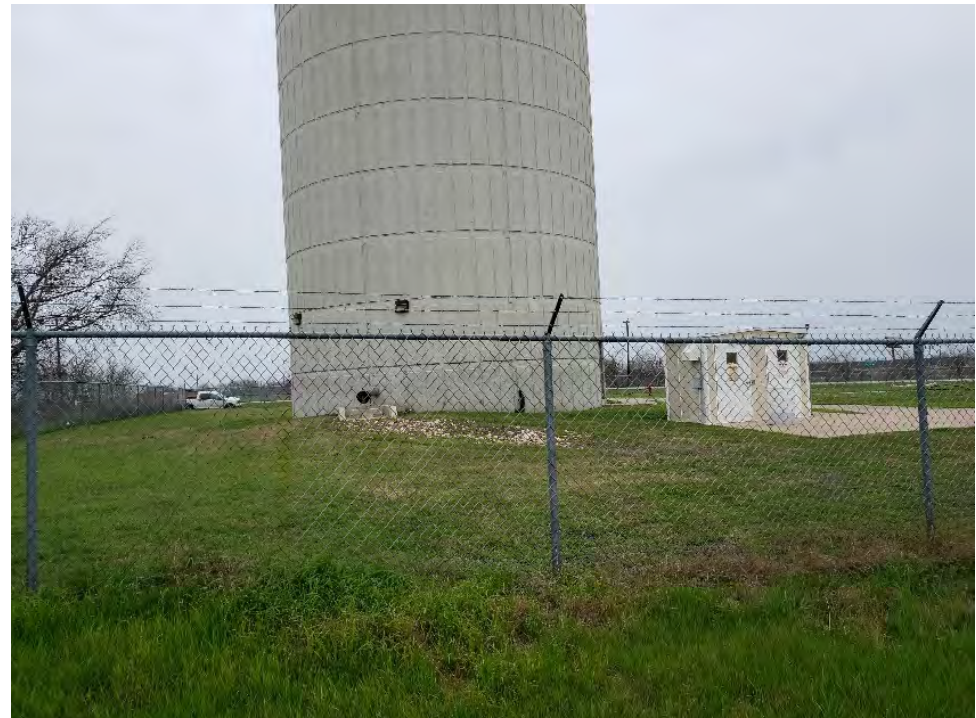

Photograph 20 - Frame Switch PS APE, view to the west.

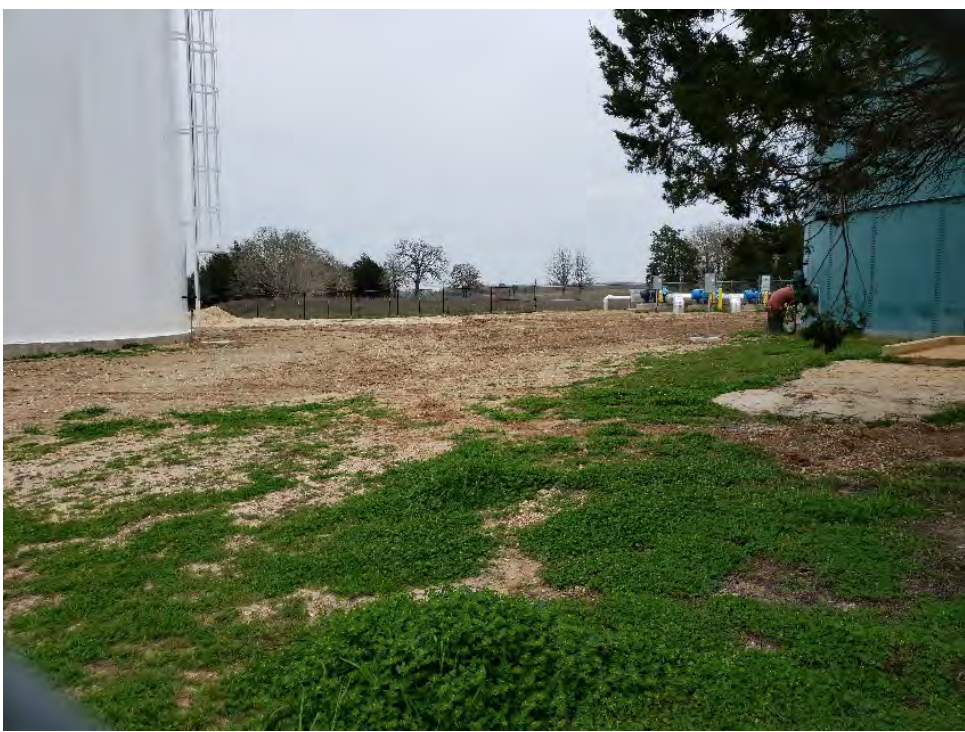

Photograph 22 - Shiloh PS APE, ground disturbance, view to the northeast.

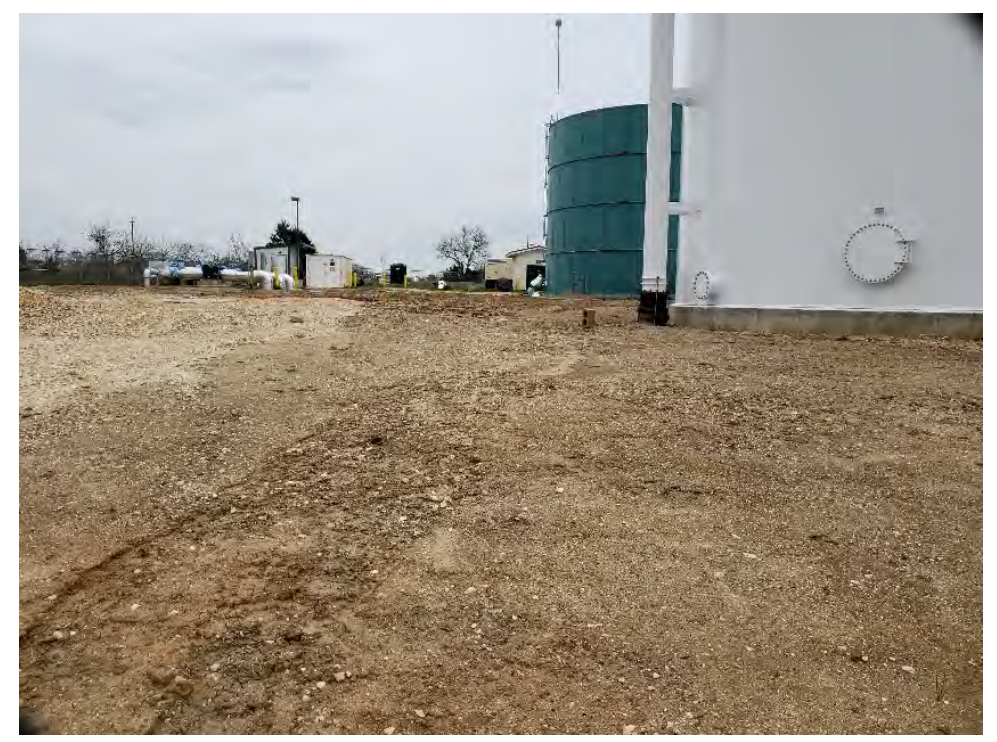

Photograph 24 - Shiloh PS APE, recent ground disturbance, view to the southeast. 


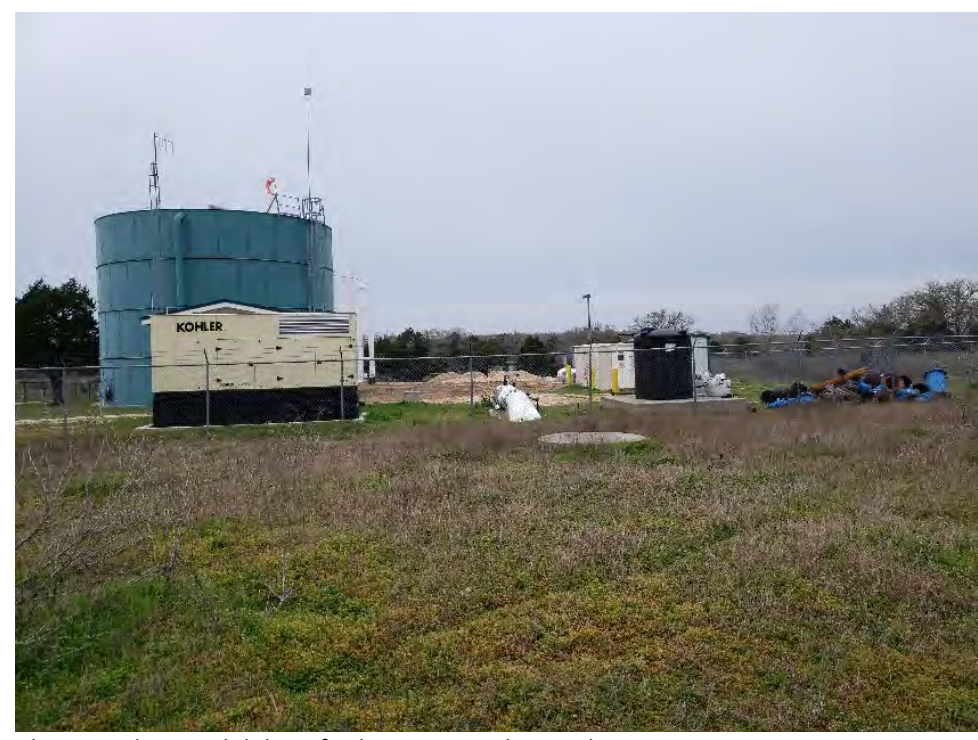

Photograph 25 - Shiloh PS facility, view to the northwest.

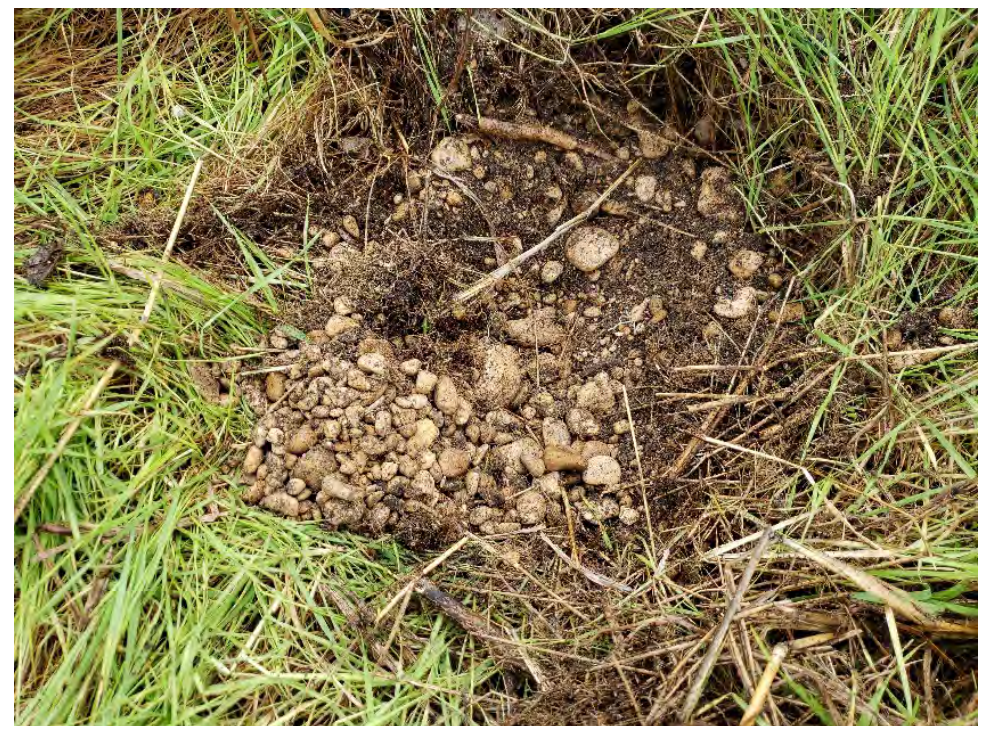

Photograph 27 - AG02 soil profile.

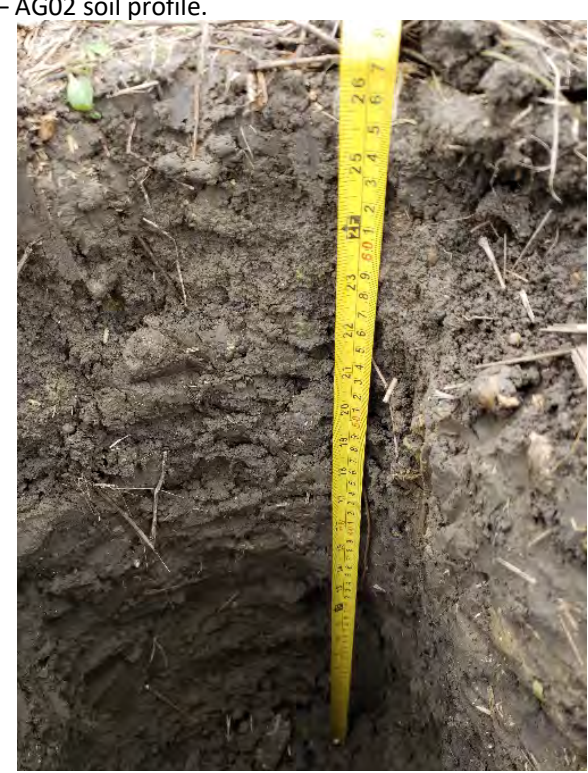

Photograph 29 - AG05 soil profile.

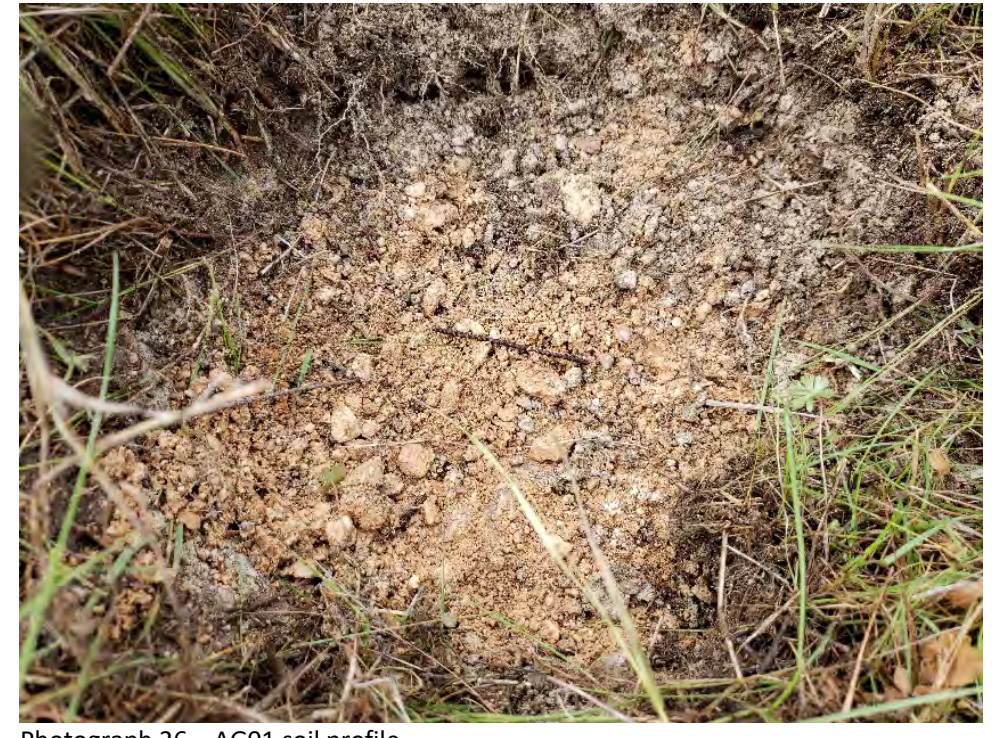

Photograph 26-AG01 soil profile.

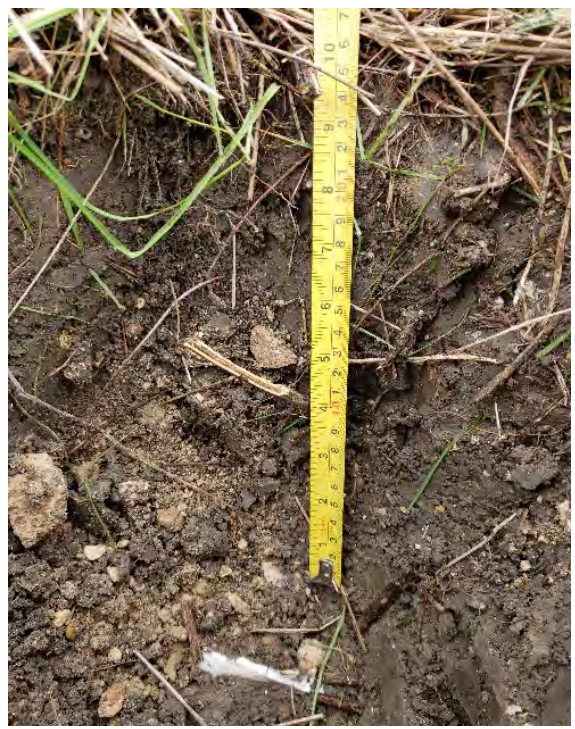

Photograph 28 - AG04 soil profile and PVC pipe.

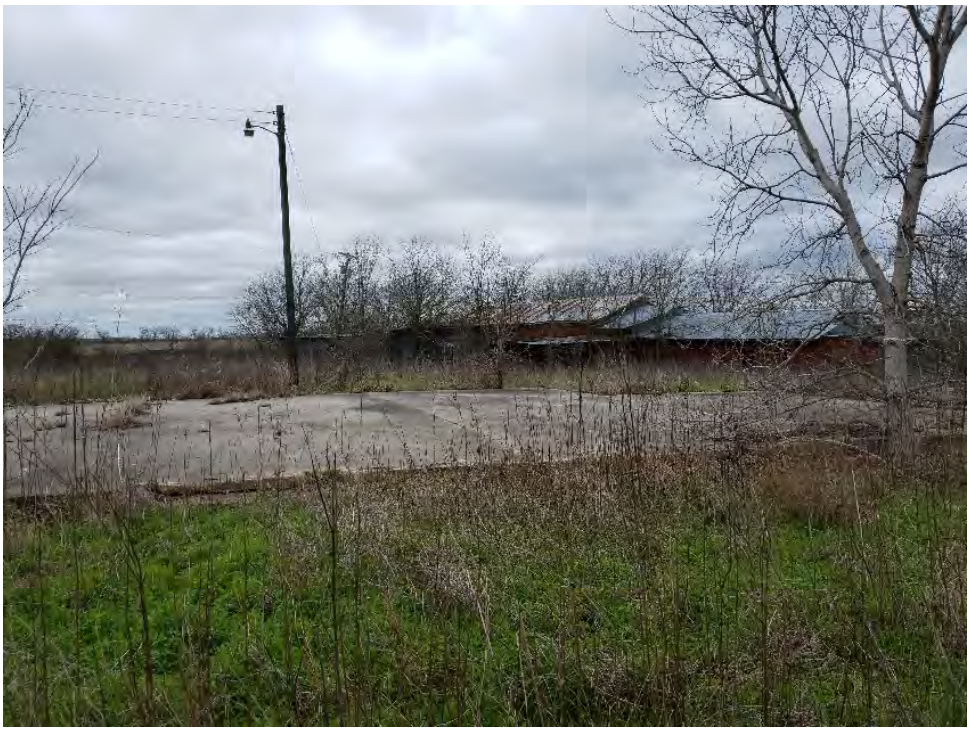

Photograph $30-41 \mathrm{WM1419}$, Feature 1 historic-age building foundation, view to the southwest. 


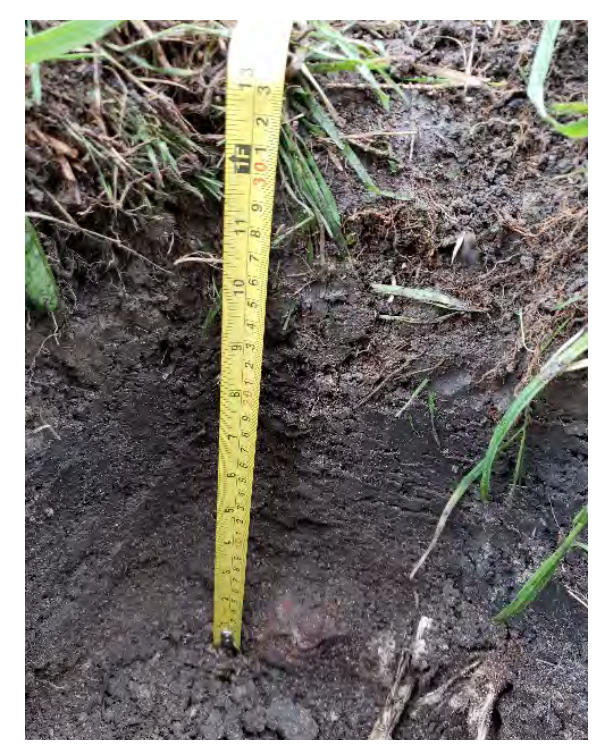

Photograph 31 -41WM1419, AG15 soil profile with in-situ brick.

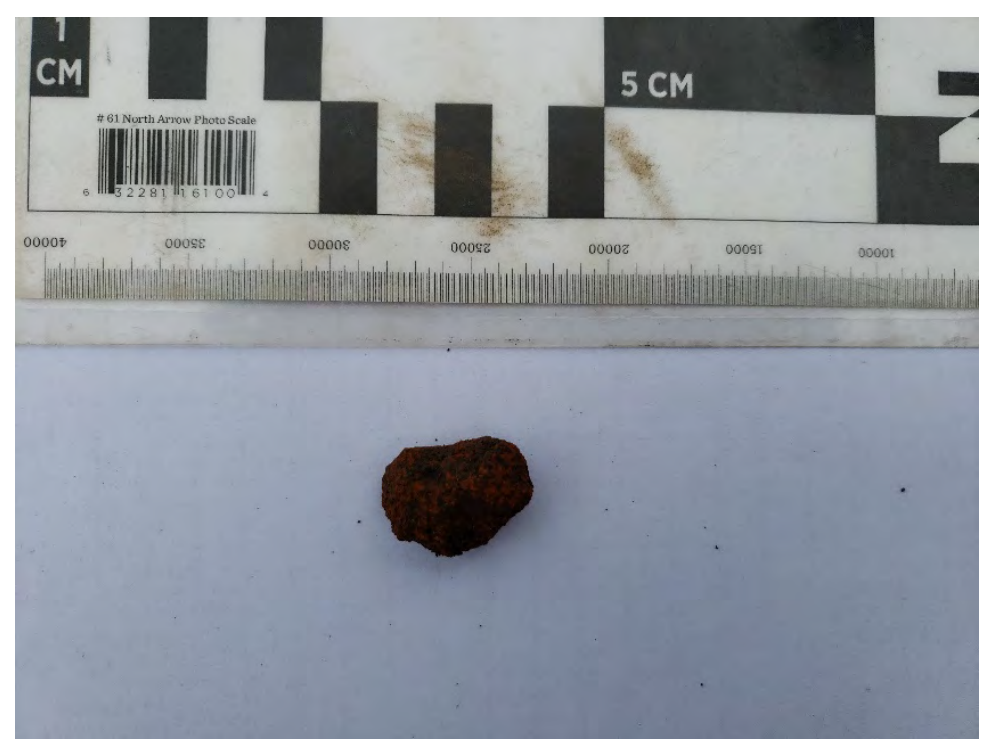

Photograph 33 -41WM1419, brick fragment from AG13.

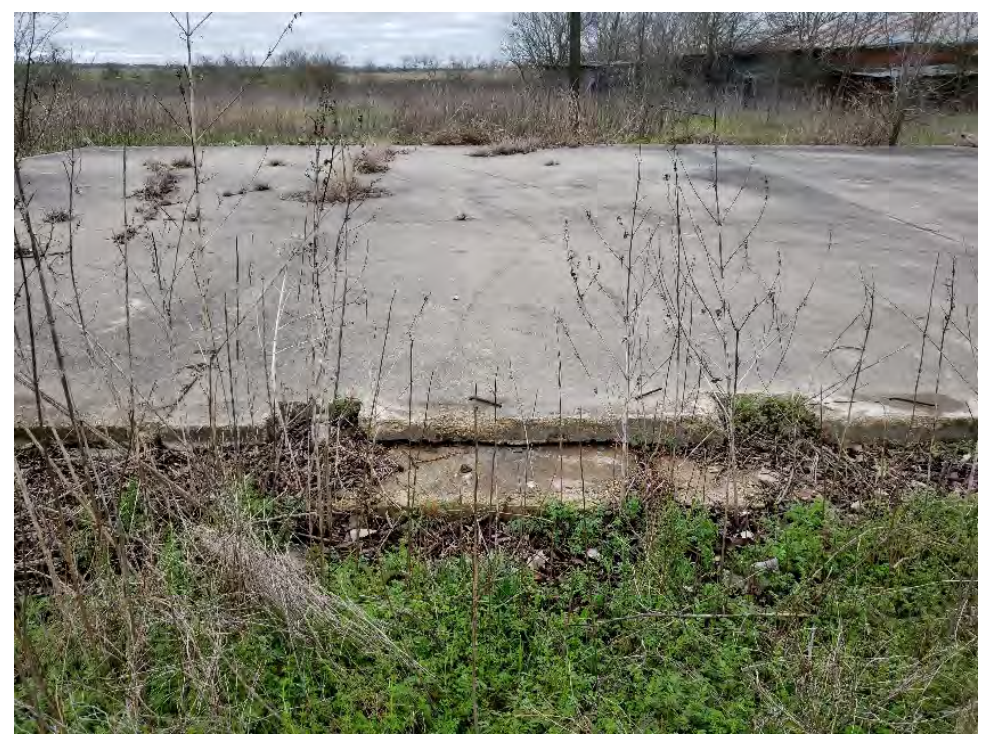

Photograph 35 -41WM1419, Feature 1, view to the southwest.

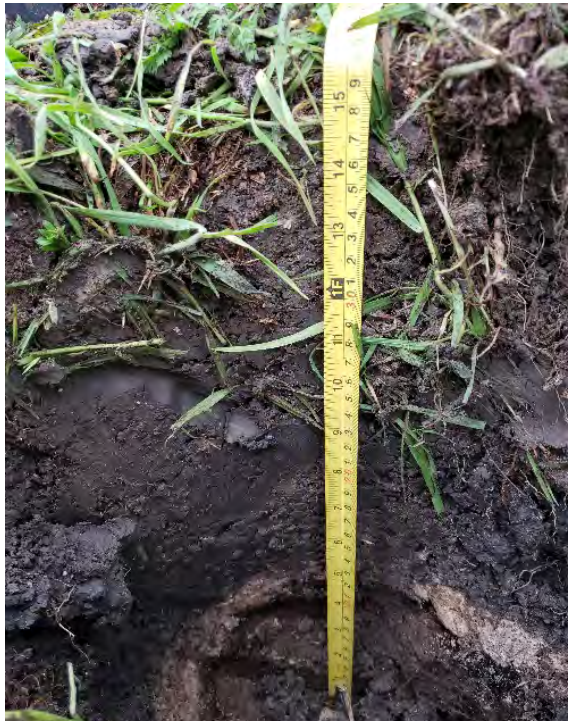

Photograph 32 -41WM1419, AG15 soil profile.

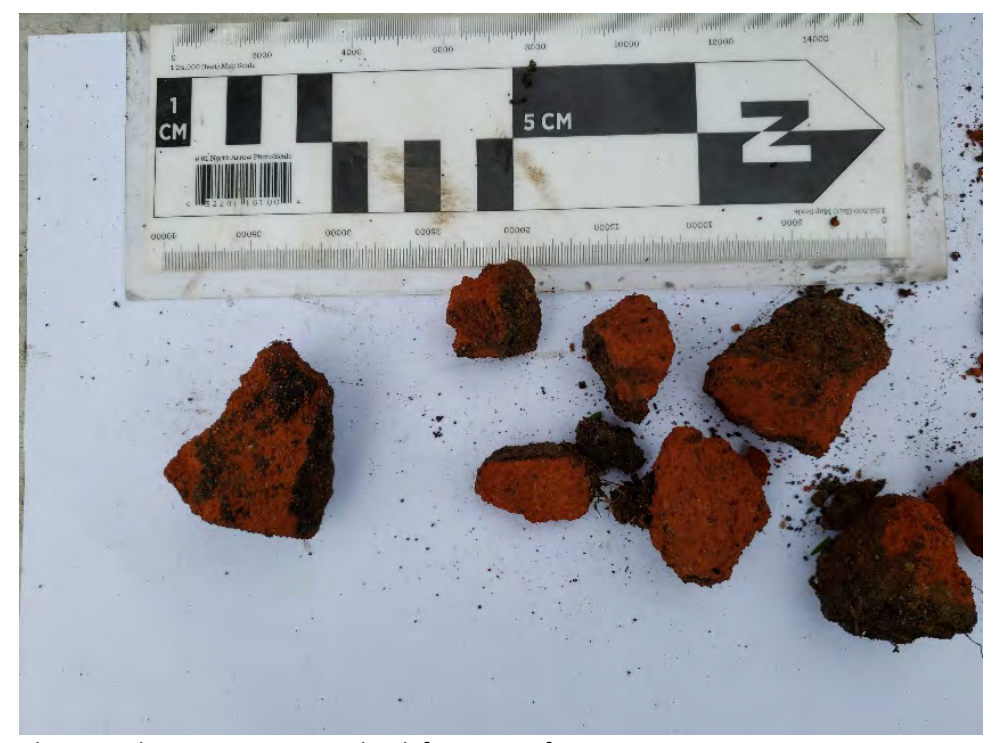

Photograph 34 - 41WM1419, brick fragments from AG15.

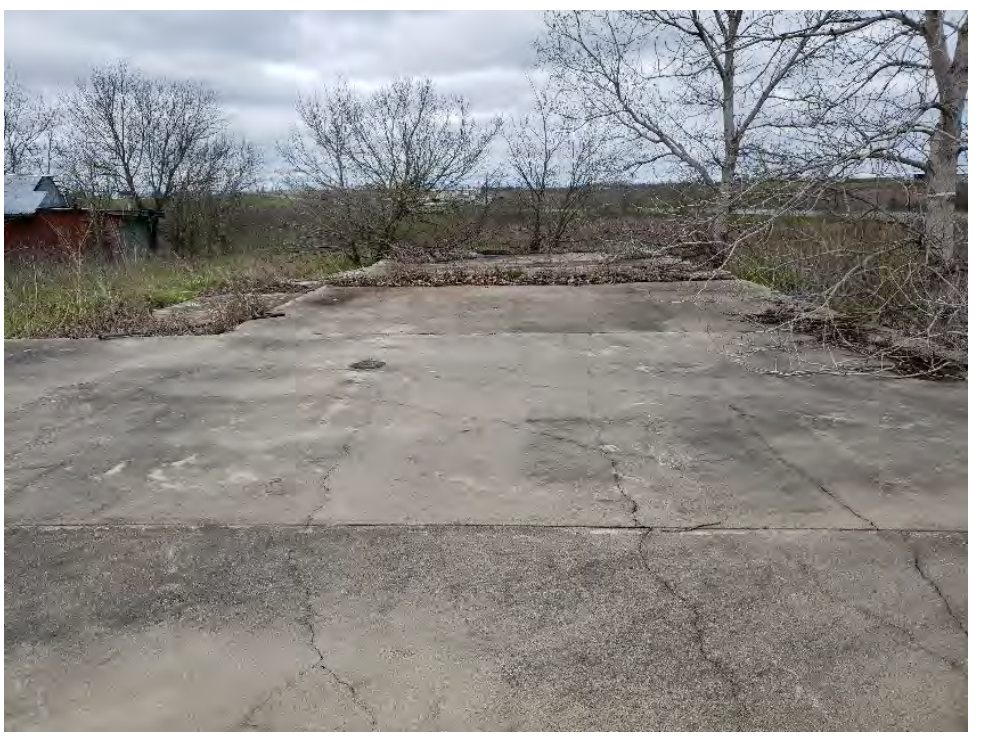

Photograph $36-41$ WM1419, Feature 1, view to the northwest. 


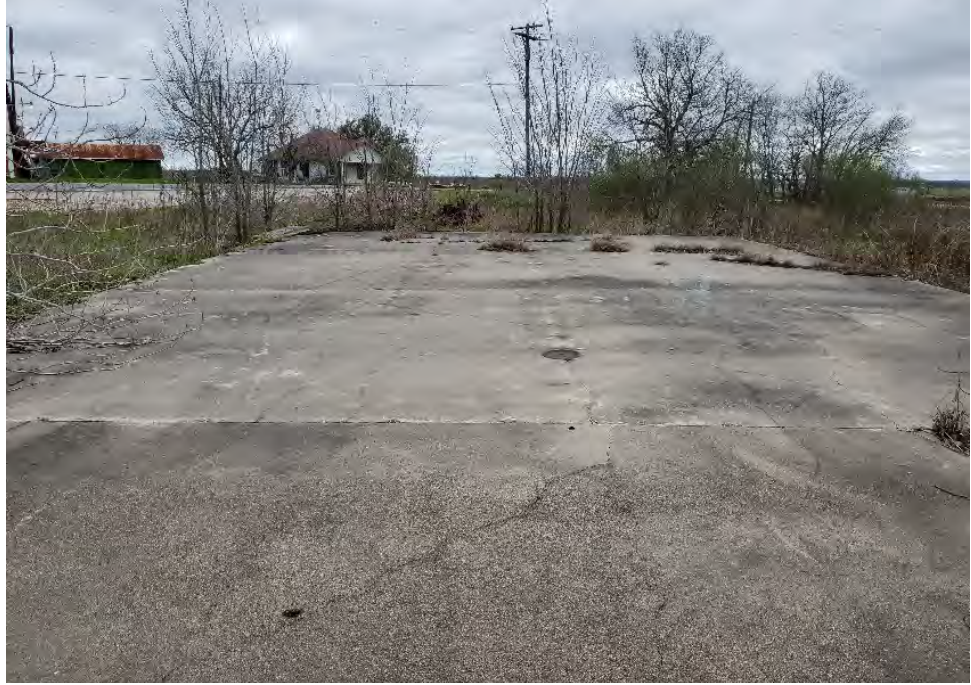

Photograph 37 - 41WM1419, Feature 1, view to the southeast.

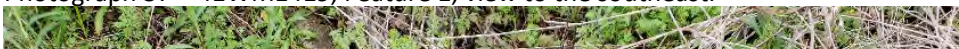

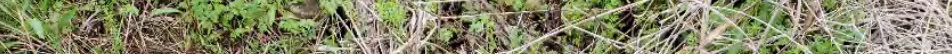
42 .

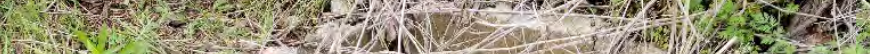

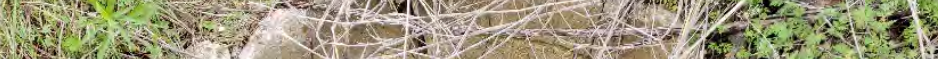

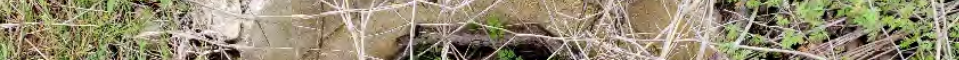

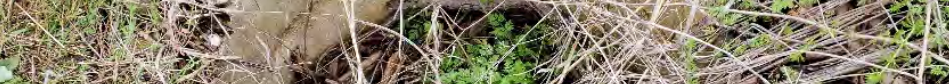

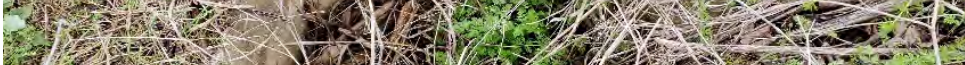

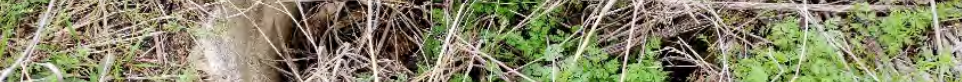

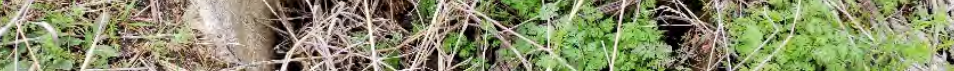

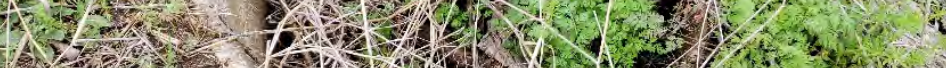

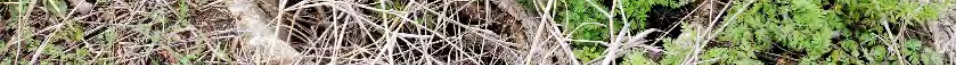
6.7.

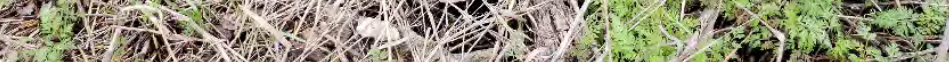

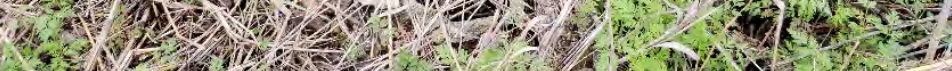

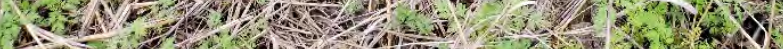

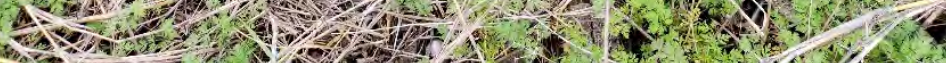

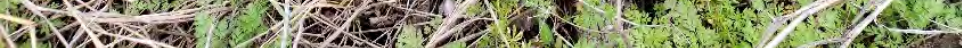
Photograph 39 - 41WM1419, Feature 2, view to the southeast.

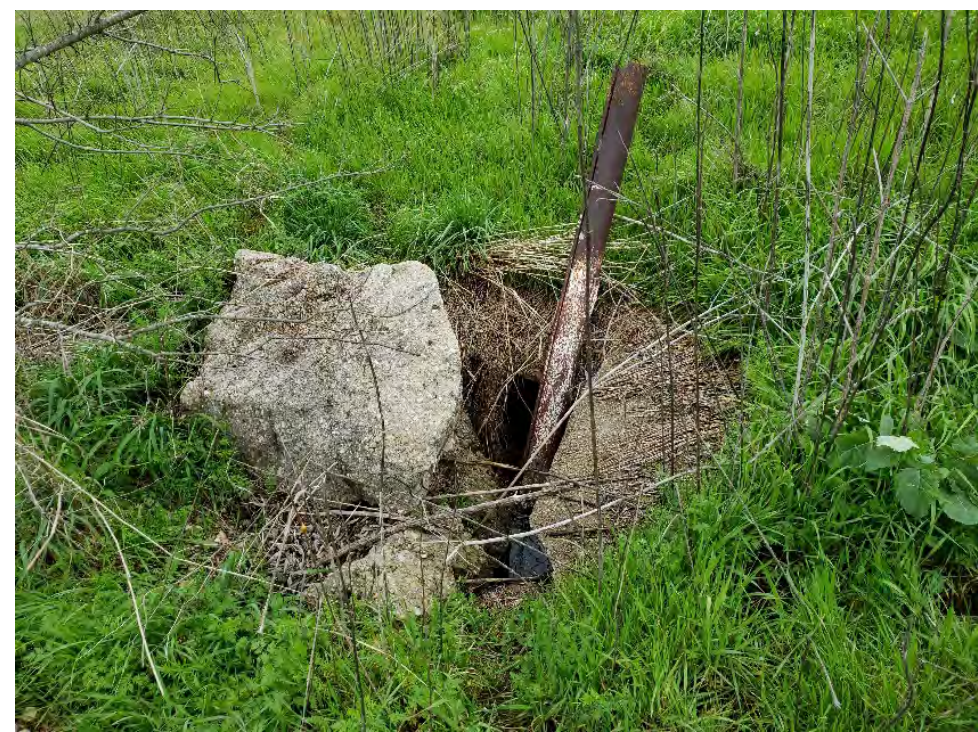

Photograph 41-41WM1419, Feature 3, view to the west.

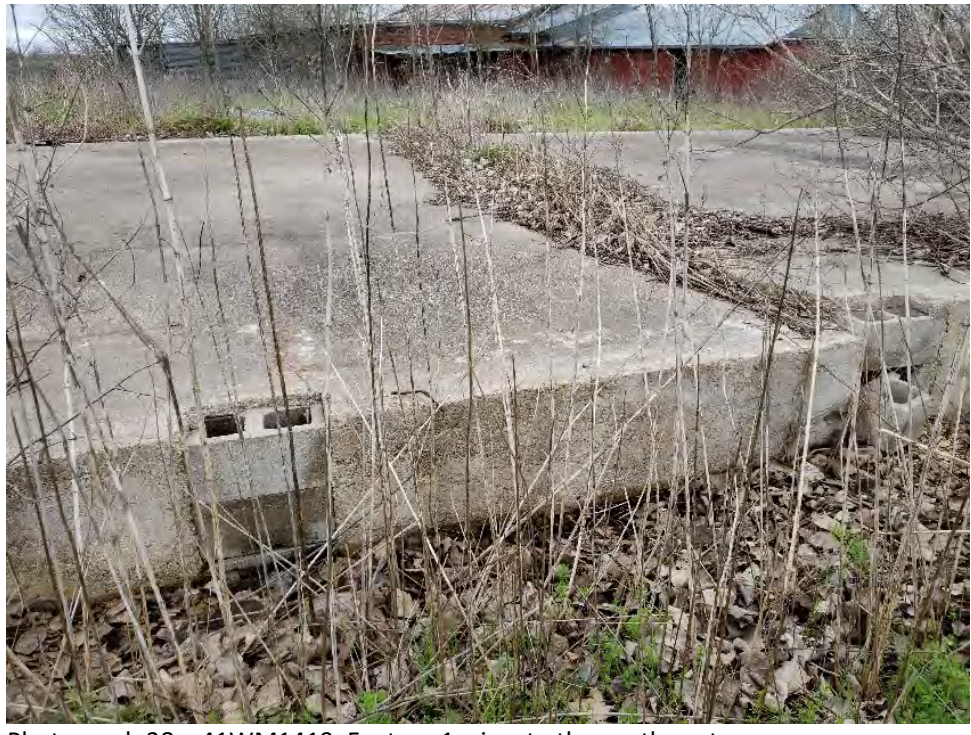

Photograph 38-41WM1419, Feature 1, view to the southwest.
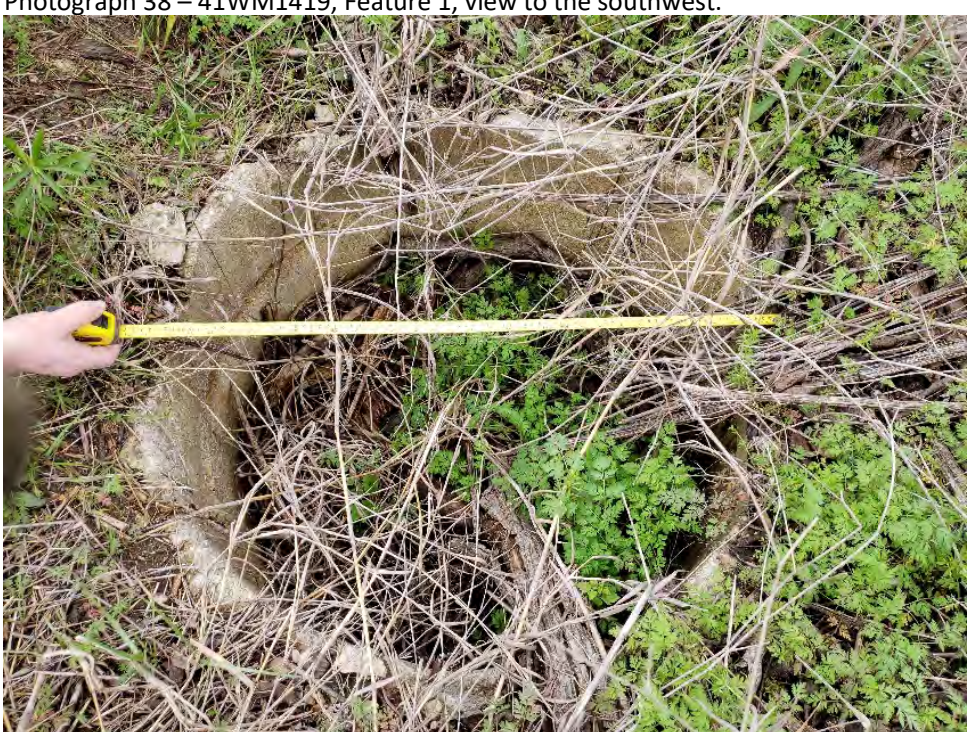

Photograph 40 - 41WM1419, Feature 2 with scale, view to the southeast.

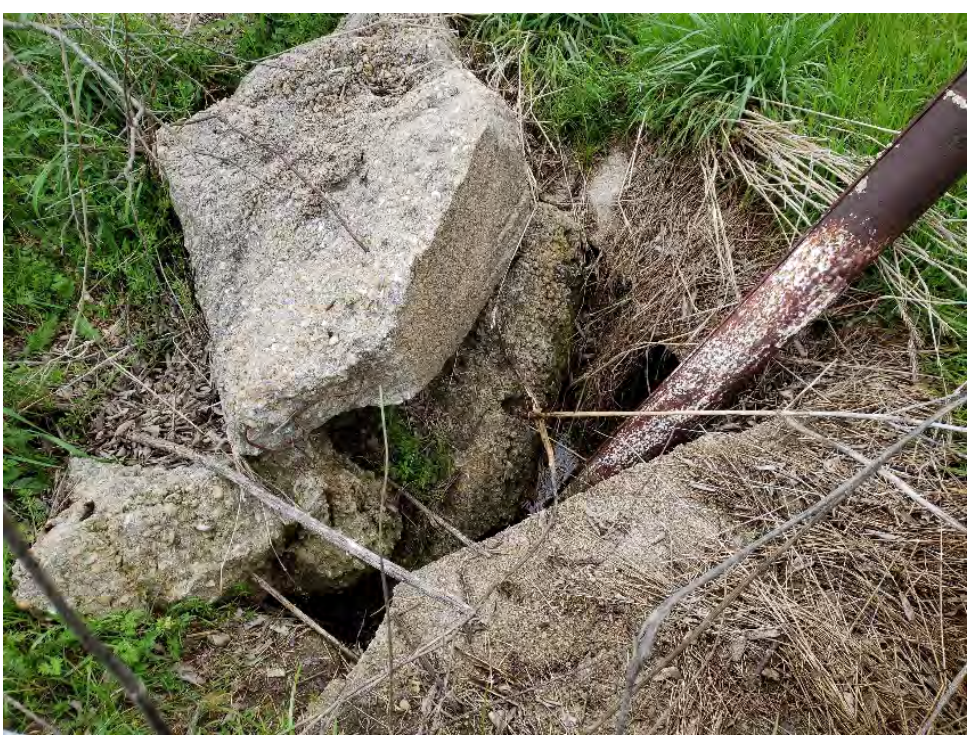

Photograph 42 - 41WM1419, Feature 3, view to the south 
APPENDIX B Architectural Resource Photograph Location Map and Photographs

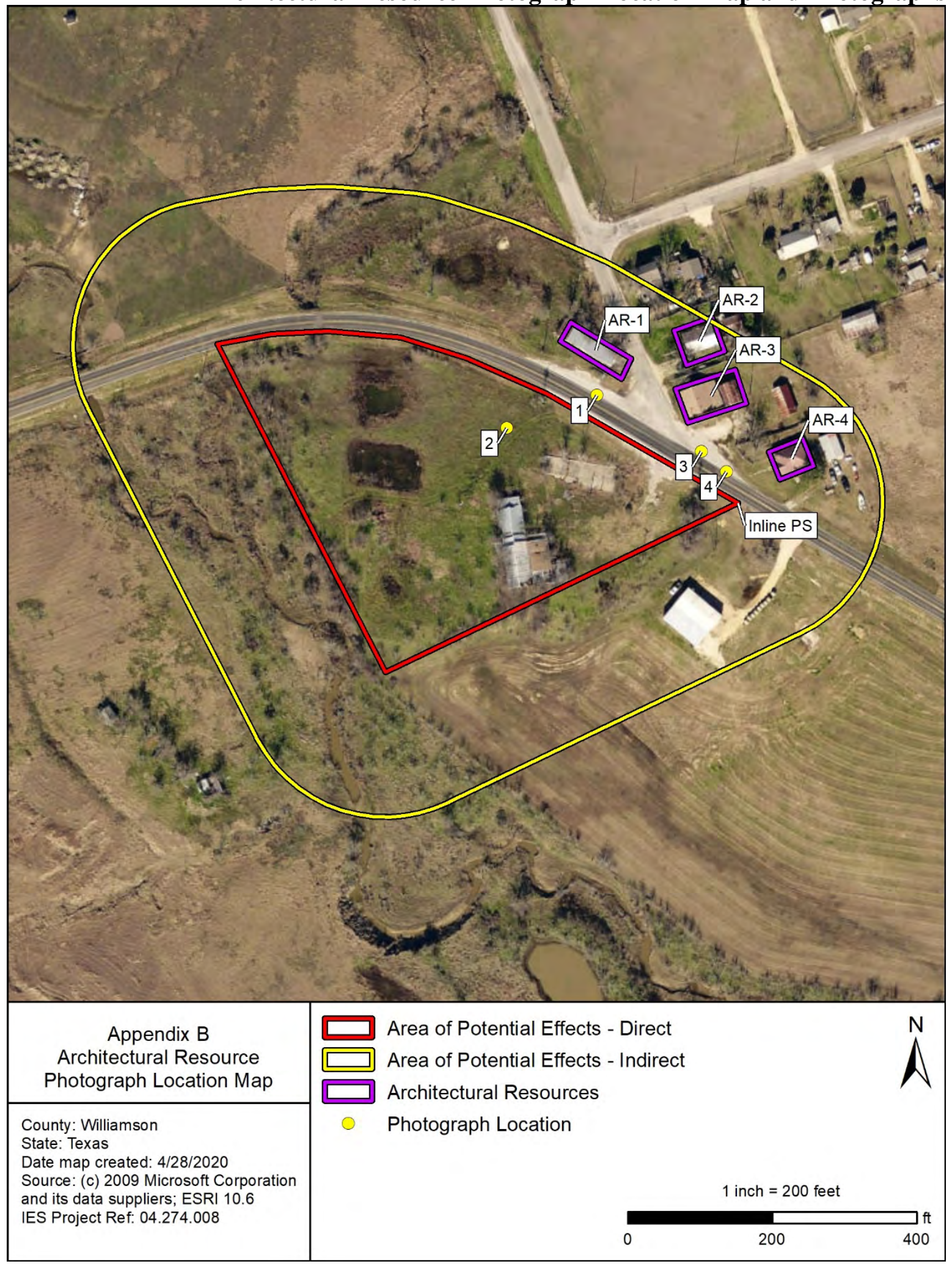




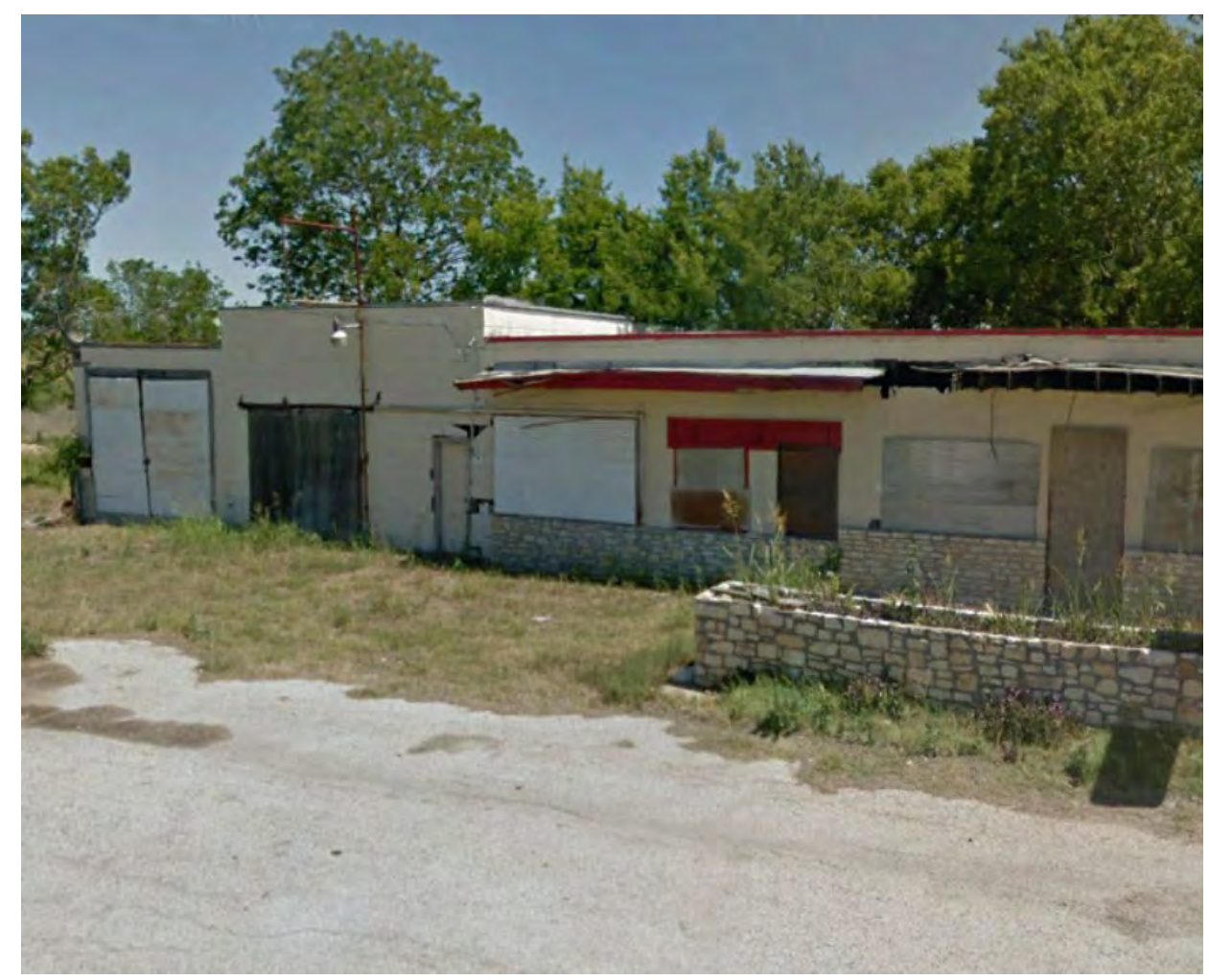

Photograph 1 - AR-1, 7361 FM 112, view to the north.

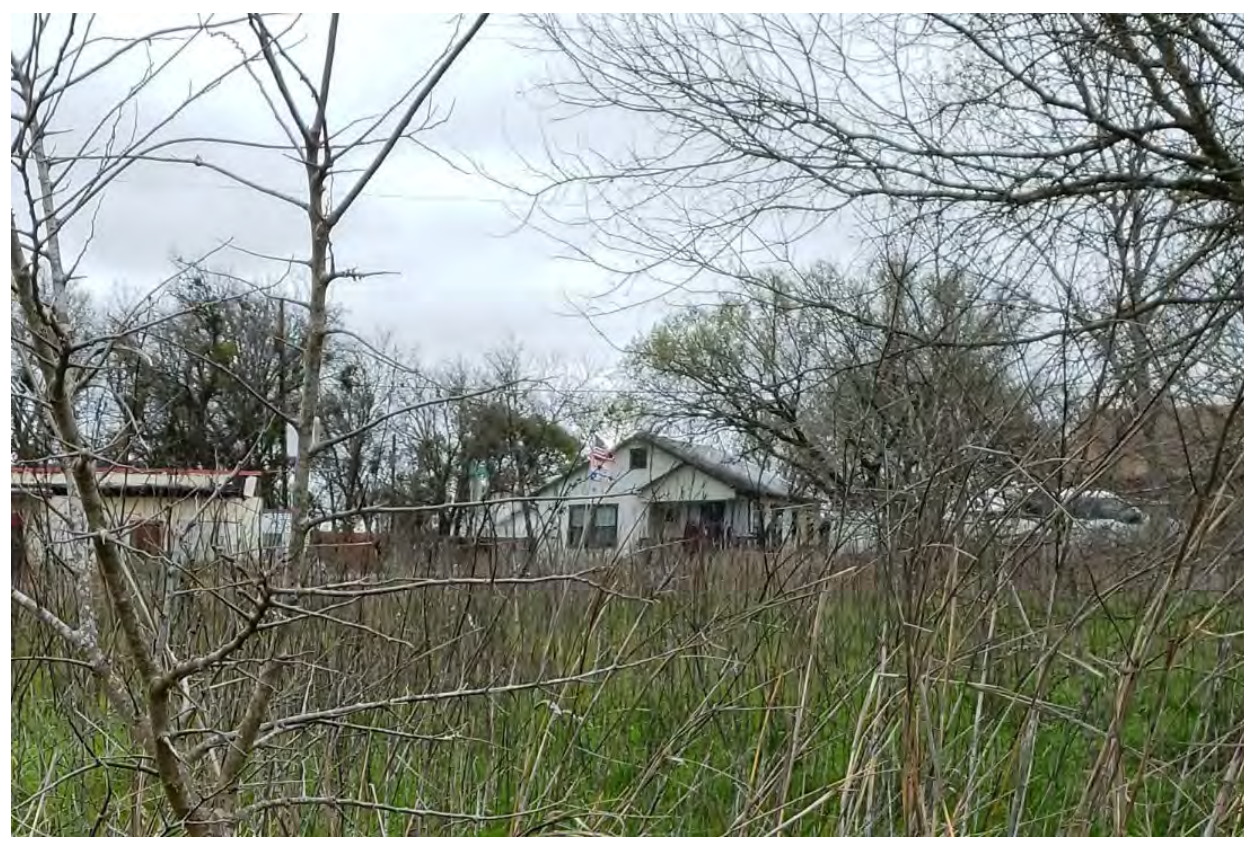

Photograph 2 - AR-2, 2121 CR 432, view to the northeast. 


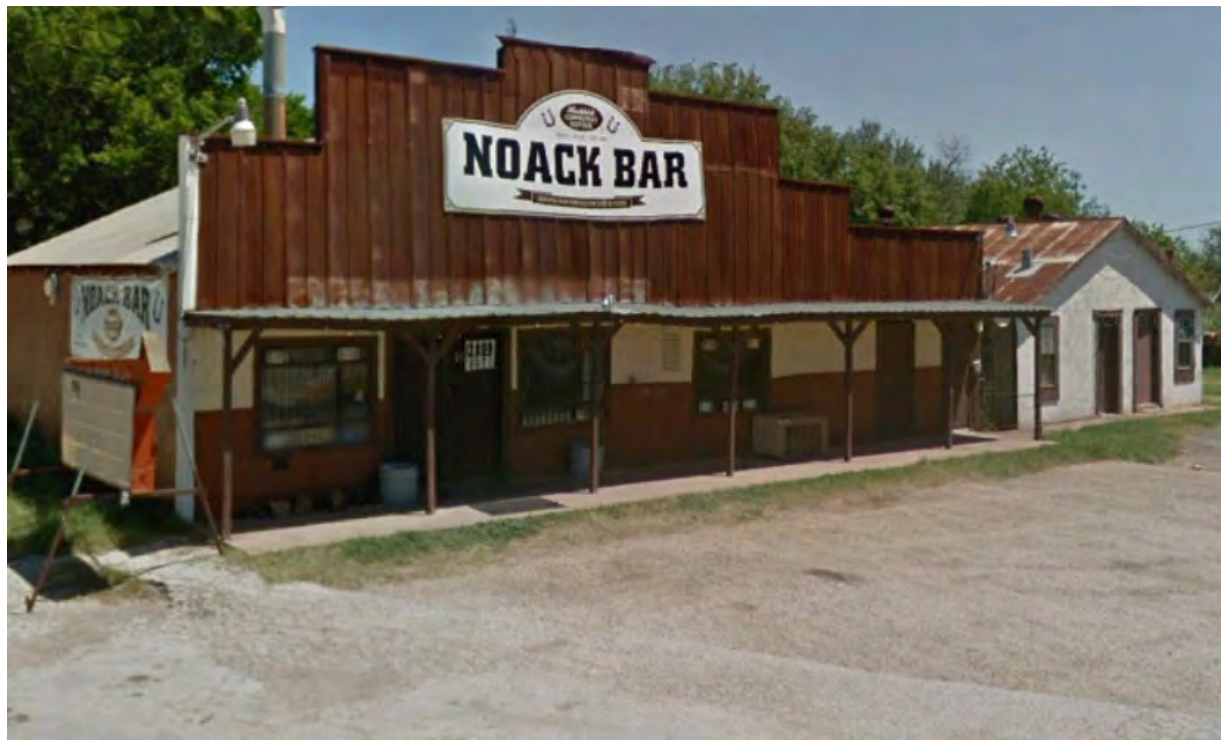

Photograph 3 - AR-3, 7401 FM 112, view to the northeast.

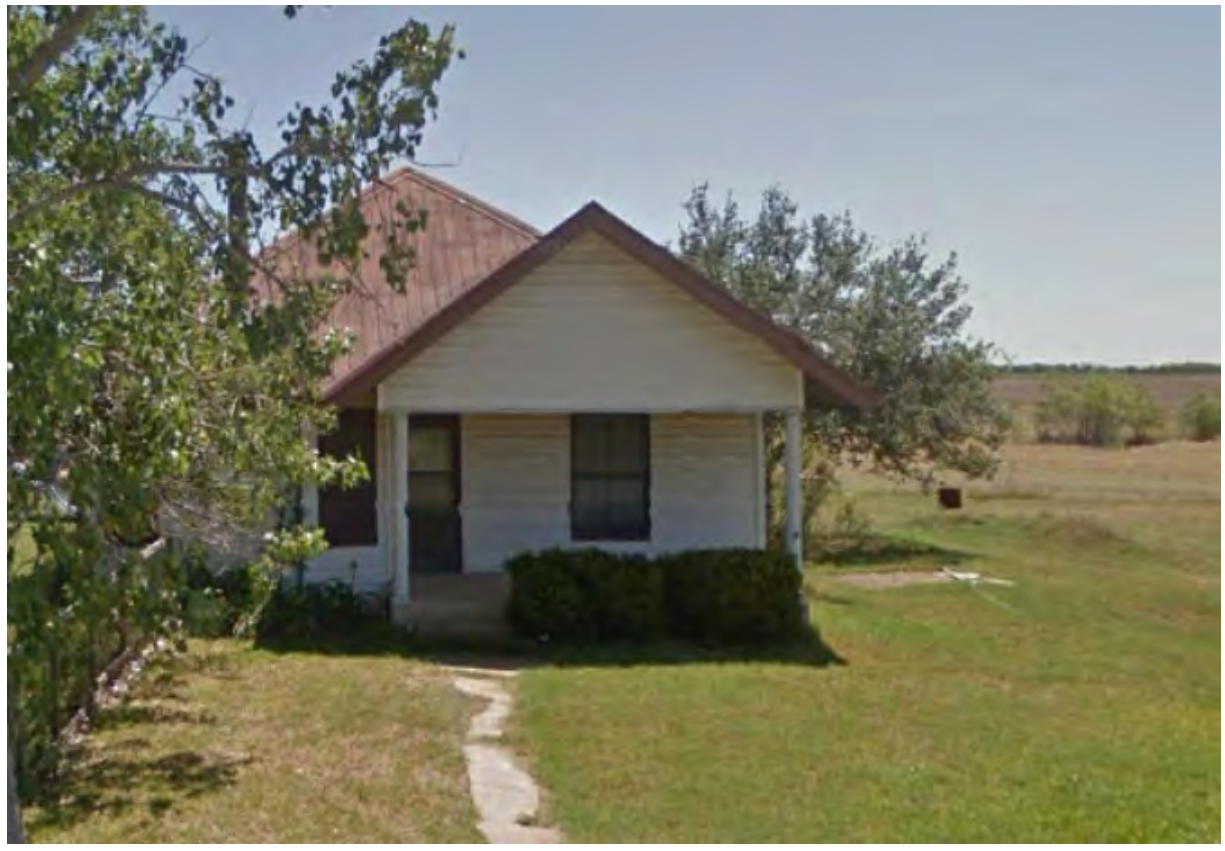

Photograph 4 -AR-3, 7411 FM 112, view to the east. 
This page intentionally left blank

COH Transmission and Distribution Pumping Stations Phase I Project

IES Project No. 04.274 .008 Cultural Resources Survey Report 


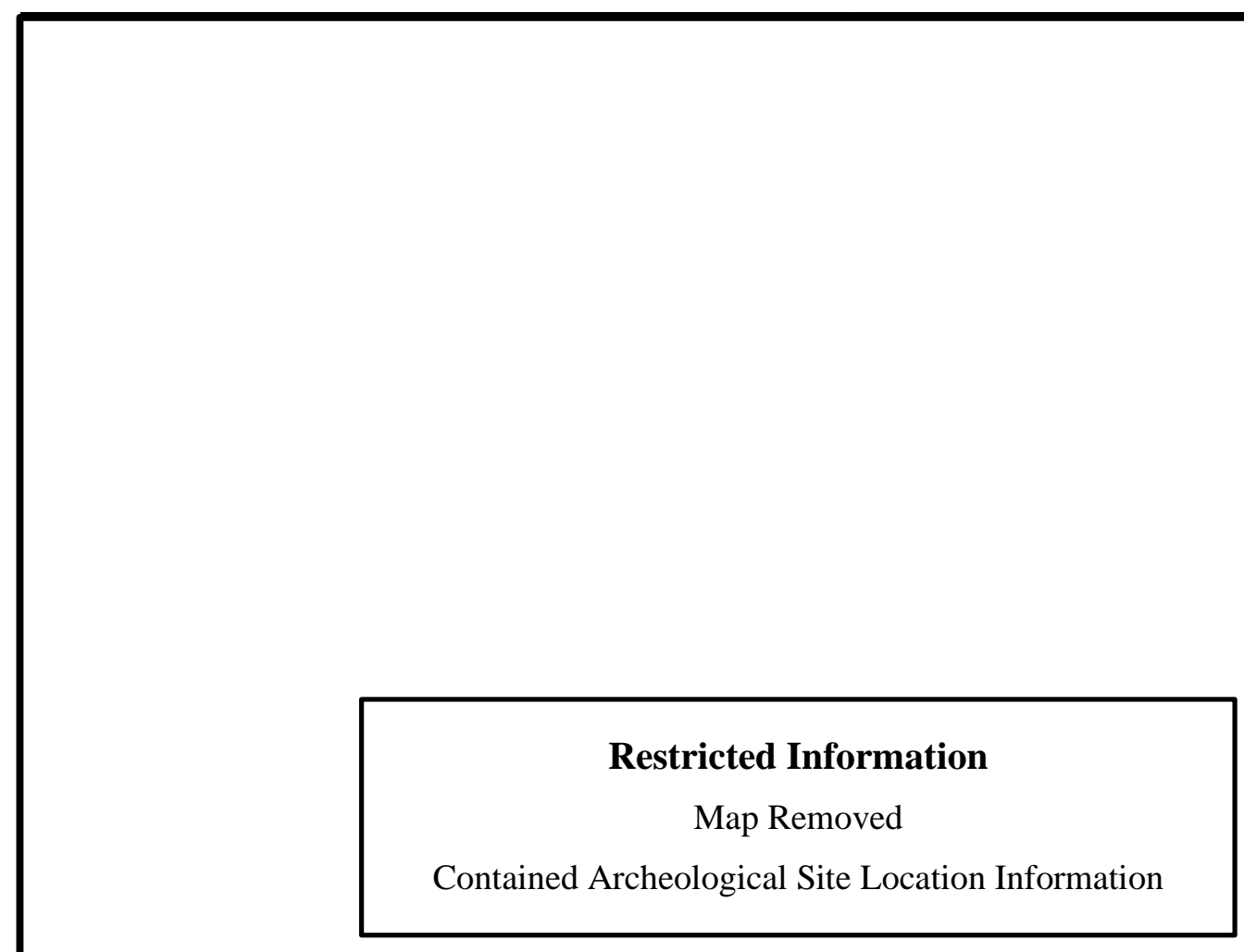


This page intentionally left blank

COH Transmission and Distribution Pumping Stations Phase I Project

IES Project No. 04.274 .008 Cultural Resources Survey Report 